\title{
12. ZONAL STRATIGRAPHY OF NEOGENE DEPOSITS OF THE EASTERN PART OF THE ATLANTIC OCEAN BY MEANS OF PLANKTONIC FORAMINIFERS, LEG 41 DEEP SEA DRILLING PROJECT
}

\author{
Valery A. Krasheninnikov, Geological Institute of the USSR Academy of Sciences, Moscow, USSR \\ and \\ Uwe Pflaumann, Geologisch-Paläontologisches Institut der Universität Kiel, \\ Olshausenstr. 40/60, 23 Kiel, Federal Republic of Germany
}

\section{SUMMARY}

During Leg 41 Neogene sediments were recovered from five sites off northwest Africa.

On the Sierra Leone Rise (Site 366), Neogene sediments consist of nanno oozes, nanno chalk, and calcareous clays 230 meters thick, resting conformably on the late Oligocene sediments. The common succession of zones occurs with two hiatuses. The lower gap corresponds to an interval around the lower/middle Miocene boundary (the Praeorbulina glomerosa and Orbulina suturalis-Globorotalia peripheroronda zones are absent) and the upper gap coincides with an interval around the middle/upper Miocene boundary (the Sphaeroidinellopsis subdehiscens-Globigerina druryi, Globigerina nepenthesGloborotalia siakensis and Globorotalia continuosa zones are missing).

In the Cape Verde Basin (Site 367) deep-water Neogene turbidites (about 200-250 m thick) contain poor fauna of redeposited and sorted Cretaceous, Eocene, Oligocene, and Neogene species.

On the Cape Verde Rise (Site 368) the Neogene section starts with slightly calcareous and noncalcareous clays with poor planktonic foraminifers of the lower Miocene. Later on this area was uplifted and clayey sediments have been replaced upsection in order by more shallow-water clayey nanno and nannoforaminifer oozes and marls and pure calcareous oozes. In the middle Miocene, planktonic foraminifers are still not diverse, but since the level of the Globigerina nepenthes-Globorotalia siakensis Zone, almost all Neogene zones have been traced. The minimum thickness of the Neogene sediments is about 230 meters.

On the continental slope off Spanish Sahara (Site 369) monotonous calcareous pelagic sediments of Neogene age (164 m thick) overlie the late Oligocene comformably, or with a small time gap. A set of zones beginning from the Globigerinoides primordisGloborotalia kugleri Zone up to the Globorotalia fohsi fohsi Zone has been revealed with a gap corresponding to the Globigerinita stainforthi and the Globigerinatella insueta-Globigerinoides trilobus zones. Above that follow sediments with heterogeneous microfauna which result from redeposition or mixing of sediments during drilling. The section ends with sediments of the late Miocene and lower Pliocene with abundant planktonic foraminifers. The latter are unconformably overlain by the Quaternary ooze.
In the Morocco basin (Site 370) deep-water marls and calcareous clays of the lower Miocene contain poor assemblages of planktonic foraminifers. The middle and upper Miocene are represented by turbidites (alternation of nanno oozes, clays, siltstones, and sands) with heterogeneous microfauna. Total thickness of Neogene is up to 200 meters.

In general the Neogene foraminifer microfauna of the area studied includes the majority of species which developed within the tropical-subtropical belt. The entire succession of the Miocene and Pliocene foraminifer zones occurs. The only exclusion is the Sphaeroidinellopsis subdehiscens-Globigerina druryi Zone of the middle Miocene.

The distribution of species is shown on three tables. Comments are given for 47 species and subspecies of foraminifers (stratigraphic ranges, peculiarities of morphology, and ultrastructure of the shell wall).

\section{INTRODUCTION}

Leg 41 of the Deep Sea Drilling Project covered the eastern part of the Atlantic Ocean, along the continental slope of Africa, between the Sierra Leone Rise in the south and the Morocco Basin in the north (Figure 1).

All seven holes drilled at five sites penetrated Neogene deposits (Table 1). On the Sierra Leone Rise (Holes 366, 366A), in the region of the Cape Verde Rise (Hole 368), and on the continental slope off Spanish Sahara (Holes 369, 369A) Neogene sediments are calcareous. Holes 366A and 369A (combined with Hole 369) were continuously cored; a significant fraction of the Neogene sediments in Hole 368 also was continuously cored. Abundant planktonic foraminifers provide distinct zonal subdivision of Neogene deposits of these regions.

In the Cape Verde Basin (Hole 367) and the Morocco Basin (Hole 370) Neogene sediment includes abyssal clay and turbidites. Coring occurred with large gaps,

TABLE 1

Data on the Holes of Leg 41

\begin{tabular}{lcccccc}
\hline Hole & $\begin{array}{c}\text { Latitude } \\
\text { (N. lat) }\end{array}$ & $\begin{array}{c}\text { Longitude } \\
\text { (W. long) }\end{array}$ & $\begin{array}{c}\text { Depth of } \\
\text { Ocean } \\
(\mathrm{m})\end{array}$ & $\begin{array}{c}\text { Depth of } \\
\text { Penetration } \\
(\mathrm{m})\end{array}$ & $\begin{array}{c}\text { Thickness } \\
\text { of Neogene } \\
(\mathrm{m})\end{array}$ & $\begin{array}{c}\text { Number of } \\
\text { Cores in } \\
\text { Neogene }\end{array}$ \\
\hline 366 & $05^{\circ} 40^{\prime} 68^{\prime \prime}$ & $19^{\circ} 51^{\prime} 08^{\prime \prime}$ & 2860 & 850.5 & & 2 \\
$366 \mathrm{~A}$ & $05^{\circ} 40^{\prime} 70^{\prime \prime}$ & $19^{\circ} 51^{\prime} 10^{\prime \prime}$ & 2860 & 367.0 & 229.5 & 25 \\
367 & $12^{\circ} 29^{\prime} 21^{\prime \prime}$ & $20^{\circ} 02^{\prime} 83^{\prime \prime}$ & 4748 & 1153.0 & $>228.0$ & 4 \\
368 & $17^{\circ} 30^{\prime} 43^{\prime \prime}$ & $21^{\circ} 21^{\prime} 23^{\prime \prime}$ & 3367 & 984.5 & $>228.0$ & 15 \\
369 & $26^{\circ} 35^{\prime} 55^{\prime \prime}$ & $1^{\circ} 54^{\circ} 56^{\prime \prime}$ & 1760 & 42.0 & 40.5 & 5 \\
$369 \mathrm{~A}$ & $26^{\circ} 35^{\prime} 55^{\prime \prime}$ & $1^{\circ} 4^{\circ} 59^{\prime} 96^{\prime \prime}$ & 1760 & 488.5 & 123.5 & 13 \\
370 & $32^{\circ} 50^{\prime} 25^{\prime \prime}$ & $10^{\circ} 46^{\prime} 56^{\prime \prime}$ & 4216 & 1176.0 & $>118.5$ & 3 \\
\hline
\end{tabular}




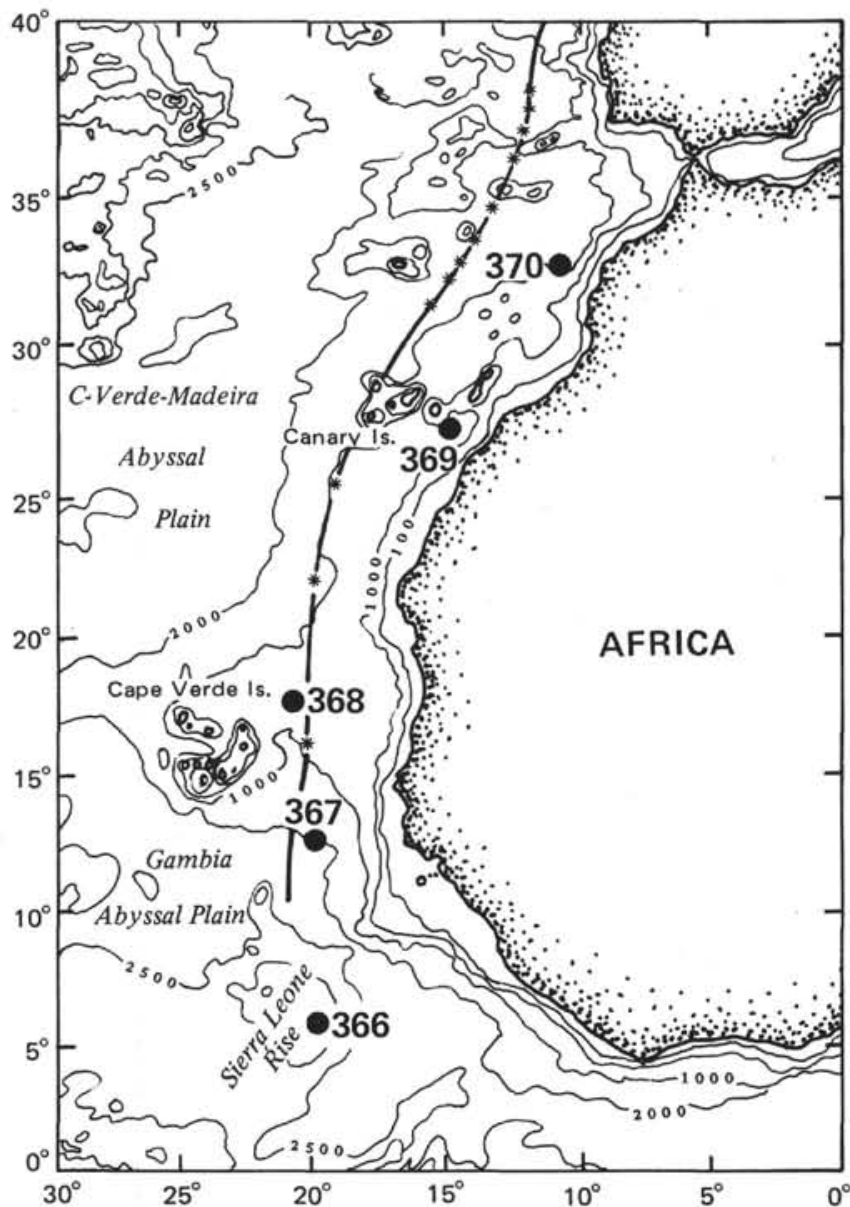

Figure 1. Location of Leg 41 Sites 366, 367, 368 369, and 370

and the planktonic microfauna were sparse. Therefore, the stratigraphic subdivision of the Neogene in these regions is less detailed.

Stratigraphy of Neogene deposits of the Atlantic Ocean off northwest Africa has been studied rather poorly. Leg 41 results significantly expand our knowledge on the Neogene stratigraphy of this region of the Atlantic Ocean.

During DSDP Legs 2, 3, and 14 in the area of the Atlantic Ocean between the Horseshoe abyssal plain in the north, and the Sierra Leone Rise in the south some holes were drilled (Peterson, Edgar, et al., 1970; Maxwell, von Herzen, et al., 1970; Hayes, Pimm, et al., 1972). Many of the holes are at oceanic depths below 4000 meters (Holes 12, 13, 135, 136, 140, 141), or even deeper than 5000 meters $(137,138)$. Stratigraphic subdivision of the Neogene sediments is difficult due to scarce fossil remains and sporadic coring.

At the southern margin of the Horseshoe abyssal plain (Hole 135) Neogene pelagic clayey nanno oozes occur unconformably on lower Eocene rocks. The lower Miocene, middle Miocene, the Globorotalia acostaensis, and the Neogloboquadrina dutertrei zones of the upper Miocene, as well as the Globorotalia margaritae Zone of the Pliocene were identified by means of planktonic foraminifers.

North of the Madeira island (Hole 136) Neogene nanno oozes overlie the Upper Cretaceous with a large gap. Planktonic foraminifers identify the middle
Miocene and the Globorotalia margaritae Zone of the Pliocene.

On the abyssal plain northwest off the Cape Verde Islands (Hole 12) and at the latitude of Cap Blanc (Holes 137 and 138), Neogene sediments are zeolitic, brown and green clays, devoid of calcareous microorganisms.

On the continental slope, roughly $250 \mathrm{~km}$ west off Cap Blanc (Hole 139) the lower Miocene is composed of diatom clays with rare planktonic foraminifers. Higher up the section foraminifer oozes and marls occur in which the Globorotalia fohsi robusta Zone of the middle Miocene, the Globorotalia margaritae and the Globorotalia miocenica zones of the Pliocene were identified from planktonic foraminifers. The thickness of Neogene-Quaternary deposits, 660 meters, is great here, which suggests an intense input of fine-grained terrigenous material.

Southwest, at the foot of the continental slope (Hole 140), Miocene abyssal clays unconformably overlie middle Eocene rocks. In clayey nanno oozes of Pliocene age, the Globorotalia-margaritae and the Globorotalia miocenica zones can be established based on planktonic foraminifers. The same zones occur in Pliocene calcareous clays north off the Cape Verde Islands (Hole 141).

On the western coast of Africa (from Morocco to Sierra Leone) the outcrops of the Neogene sediments occupy rather limited areas. The most complete sections are on the Morocco coast (Casablanca to Tangier), but foraminifers here have been poorly studied. To the south, for instance in Senegal, Neogene sediments occur mostly as shallow-water deposits of lower and middle Miocene age with benthic foraminifers and molluscs. Planktonic remains are absent.

Neogene stratigraphic subdivisions are controversial. Therefore, it is necessary to explain the position of the boundaries between the stratigraphic units used in this paper: The base of the Globigerinoides primordiusGloborotalia kugleri Zone (the Globigerinoides datumplane) is adopted as the lower boundary of Neogene; the base of the Orbulina suturalis-Globorotalia peripheroronda Zone (the Orbulina datum-plane) is considered the lower boundary of middle Miocene; the problem of the boundary between the middle and upper Miocene is complicated. This boundary is conditionally the base of the Globorotalia continuosa Zone, i.e., the Tortonian stage is included into the upper Miocene. Also difficult is the problem of the Miocene-Pliocene boundary. The base of the Globorotalia margaritae evoluta Zone (the Sphaeroidinella datum-plane) is adopted as such. The base of the Globorotalia truncatulinoides Zone is regarded as the boundary between Pliocene and Quaternary deposits.

\section{REGIONAL STRATIGRAPHY}

Regional stratigraphy of Neogene deposits of the eastern part of the Atlantic Ocean is presented in the direction from the Sierra Leone Rise in the south to the Morocco Basin in the north.

\section{Sierra Leone Rise}

The Miocene deposits on the Sierra Leone Rise conformably overlie upper Oligocene sediments (the 
Globorotalia kugleri s. str. Zone). The lower and middle Miocene are presented by alternations of nanno oozes, nanno chalk, nanno marls, and calcareous clays of pale gray, greenish, and yellowish colors (Site 366).

The upper Miocene and Pliocene are composed of nanno and nanno foraminifer oozes and marls of pale gray and greenish tints.

The following zones are distinguished in the lower Miocene:

1) The Globigerinoides primordius-Globorotalia kugleri Zone, where the index species occur with numerous Globigerina venezuelana, G. bradyi, $G$. juvenilis, G. praebulloides, G. angustiumbilicata, Globorotalia siakensis combined with less distributed Globigerinita dissimilis, G. unicava, G. stainforthi praestainforthi, Cassigerinella chipolensis, Globigerina woodi, G. binaiensis, Globoquadrina praedehiscens, G. altispira globosa, Globorotaloides suteri, Globorotalia nana. In the upper part of the zone appear Globigerinoides trilobus and $G$. altiaperturus. Thickness is 20.5 meters. Interval: from $366 \mathrm{~A}-26-1,61-63 \mathrm{~cm}$ to 366A-28-1, 91-93 cm;

2) The Globigerinita dissimilis Zone that is characterized by a similar assemblage of planktonic foraminifers, but Globigerinoides trilobus, $G$. altiaperturus, Globigerinita stainforthi, Globoquadrina altispira become typical species, whereas Globorotalia kugleri and Globigerinoides primordius disappear. Thickness is 28.5 meters. Interval: from $366 \mathrm{~A}-23-1,47-$ $49 \mathrm{~cm}$, to $366 \mathrm{~A}-25, \mathrm{CC}$;

3) The undifferentiated Globigerinita dissimilisGlobigerinita stainforthi zones with an assemblage of planktonic foraminifers as in underlying deposits. There appear only rare specimens of Globorotalia peripheroronda; Globigerinita dissimilis and Globigerinoides altiaperturus being sporadic. By the stratigraphic position below the Globigerinatella insueta-Globigerinoides trilobus Zone, the above sediments should be attributed to the Globigerinita stainforthi and Globigerinita dissimilis zones, as the absence of Globigerinatella insueta does not allow us to draw the boundary between them. Thickness is 28.5 meters. Interval: from 366A-20-1, 121-123 cm, to 366A22 , CC. There was no recovery in Core 366A-19;

4) The Globigerinatella insueta-Globigerinoides trilobus Zone characterized by wide development of Globigerinoides trilobus, Globoquadrina dehiscens, $G$. altispira, G. altispira globosa, Globorotalia siakensis, G. peripheroronda, Globigerina juvenilis, G. angustiumbilicata, G. conglomerata. Less frequently recovered are Globigerinoides diminutus, G. subquadratus, Globoquadrina larmeui, Globorotaloides suteri, Globigerina foliata, $G$. bollii, $G$. venezuelana, Cassigerinella chipolensis, Globorotalia obesa, $G$. continuosa, G. minutissima. Such species as Globoquadrina praedehiscens, Globigerinita stainforthi, and $G$. unicava occurred as single specimens. Specimens of Globigerinatella insueta occurred only in Sample $366 \mathrm{~A}-18-1,61-63 \mathrm{~cm}$. Thickness is 19 meters. Interval: from $366 \mathrm{~A}-16, \mathrm{CC}$ to $366 \mathrm{~A}-18, \mathrm{CC}$.

The total thickness of the lower Miocene is 106 meters. Between the lower and middle Miocene one can clearly mark disconformity by the omission of two zones-Praeorbulina glomerosa (the uppermost parts of the lower Miocene) and Orbulina suturalis-Globorotalia peripheroronda (basal layers of the middle Miocene).

The middle Miocene includes:

1) The Globorotalia peripheroacuta Zone where the zonal species is accompanied by Globorotalia peripheroronda, G. obesa, G. siakensis, G. archaeomenardii, G. (Clavatorella) bermudezi, Globigerinoides trilobus, Globoquadrina dehiscens, G. altispira, G. altispira globosa, G. langhiana, Globigerina juvenilis, Sphaeroidinellopsis seminulina. Thickness is 6 meters. Interval: from $366 \mathrm{~A}-16-3,117-119 \mathrm{~cm}$, to $366 \mathrm{~A}-16-5$, $66-68 \mathrm{~cm}$;

2) The Globorotalia fohsi fohsi Zone in which the significant elements of microfauna are the index species, Globorotalia peripheroacuta, G. peripheroronda, $G$. siakensis, G. praemenardii, $G$. archeomenardii, Sphaeroidinellopsis seminulina, Globoquadrina dehiscens, G. altispira, and rare specimens of Orbulina suturalis. Species also occur from sediments of the underlying zone. Thickness is 5.5 meters. Interval: from $366 \mathrm{~A}-15-6,61-63 \mathrm{~cm}$, to $366 \mathrm{~A}-16-2,61-63 \mathrm{~cm}$;

3) The Globorotalia fohsi lobata Zone where the index species appears with a clear keel along the peripheral margin of the test. An assemblage of planktonic foraminifers is similar to that from the underlying zone; Globorotalia scitula s. 1. belongs to the new elements; $G$. peripheroronda and $G$. peripheroacuta disappear; Orbulina suturalis is unexplainably absent. Thickness is 4.5 meters. Interval: from $366 \mathrm{~A}-15-3$, 61$63 \mathrm{~cm}$ to $366 \mathrm{~A}-15-5,61-63 \mathrm{~cm}$.

The total thickness of the middle Miocene is 16 meters.

The upper Miocene occurs unconformably on middle Miocene sediments. The gap corresponds to three zones: Sphaeroidinellopsis subdehiscens-Globigerina druryi Zone, Globigerina nepenthes-Globorotalia siakensis Zone (middle Miocene), and Globorotalia continuosa Zone (upper Miocene).

The upper Miocene consists of the following zonal subdivisions:

1) The Globorotalia acostaensis Zone with numerous specimens of the index species, G. merotumida, $G$. menardii, G. cultrata, Sphaeroidinellopsis subdehiscens, Sph. seminulina, Globigerinoides bollii, G. trilobus, Globoquadrina altispira, G. altispira globosa, $G$. dehiscens, Globigerina conglomerata, G. juvenilis, $G$. nepenthes. Such species as Orbulina universa, $O$. suturalis, Globorotaloides variabilis, Globigerinoides obliquus obliquus, Globorotalia obesa, G. lenguaensis are less distributed. Thickness is 12.5 meters. Interval: from $366 \mathrm{~A}-14-1,71-73 \mathrm{~cm}$, to $366 \mathrm{~A}-15-2,61-63 \mathrm{~cm}$;

2) The Globorotalia plesiotumida Zone characterized by appearance of the index species, Globorotalia dutertrei, G. miozea, Globigerinoides obliquus extremus, Candeina nitida. There are numerous specimens of Globorotalia menardii, Orbulina universa, Sphaeroidinellopsis subdehiscens, Sph. seminulina, Globoquadrina altispira, $G$. dehiscens, Globigerina nepenthes, Globigerinoides bollii, G. trilobus, G. obliquus obliquus. Thickness is 27 meters. Interval: from 366A$11-2,61-63 \mathrm{~cm}$, to $366 \mathrm{~A}-13, \mathrm{CC}$;

3) The Globorotalia margaritae margaritae Zone with the index species and G. margaritae primitiva. Other species of planktonic foraminifers from 
underlying deposits still occur-Globorotalia menardii, $G$. cultrata, G. acostaensis, Globigerina nepenthes, Globigerinoides obliquus obliquus, G. obliquus extremus, G. trilobus, Sphaeroidinellopsis subdehiscens, Sph. seminulina, Globoquadrina altispira, G. dehiscens, Candeina nitida, Orbulina universa, etc. This zone is the final occurrence of Globorotalia plesiotumida and $G$. merotumida and sporadic specimens of Globigerinoides conglobatus appear. No Globorotalia tumida have been recognized, although this species is representative of synchronous sediments in other regions of the world. The lower and the upper boundaries of the Globigerina margaritae margaritae Zone are not well pronounced owing to a gradual change of microfauna. Therefore, the thickness of the zone is estimated roughly as 11 meters. Interval: from 366A-10-1, 89-91 cm to 366A-11$1,107-109 \mathrm{~cm}$.

The thickness of upper Miocene deposits is 50.5 meters. The total thickness of the Miocene is 172.5 meters.

Pliocene deposits occur conformably on the Miocene and are subdivided into three zones:

1) The Globorotalia margaritae evoluta Zone, characterized by extremely diverse planktonic foraminifers, contains: the index species, Globorotalia margaritae margaritae, G. menardii, G. cultrata, G. pertenuis, G. hirsuta, G. pseudomiocenica, $G$. multicamerata, G. dutertrei, G. crassaformis, Sphaeroidinella dehiscens, Sphaeroidinellopsis subdehiscens, Sph. seminulina, Sph. sphaeroides, Globigerinoides conglobatus, G. ruber, G. sacculifer, $G$. trilobus, G. obliquus obliquus, G. obliquus extremus, Candeina nitida, Pulleniatina primalis, $P$. obliquiloculata, Orbulina universa, Globoquadrina altispira, G. dehiscens, Globorotaloides hexagonus, Globigerinella siphonifera, Globigerina nepenthes, $G$. bulloides, $G$. conglomerata. In the upper part of the zone appear Globorotalia exilis, Globigerinoides trilobus fistulosus and sporadic Globorotalia miocenica. Thickness is 38.0 meters. Interval: from $366 \mathrm{~A}-6-1,81-$ $83 \mathrm{~cm}$ to $366 \mathrm{~A}-9, \mathrm{CC}$.

There is a capricious distribution of some species of planktonic foraminifers. In the lower part of the zone (Core 366A-9) Globorotalia margaritae evoluta is rarely observed; in some samples from Cores 366A-8 and 366A-6 this species was not recovered at all. In the majority of the samples of Core 366A-7 no $G$. margaritae, G. menardii, G. cultrata have been recognized. The latter two species are also partially absent in Core 366A-6 too. The number of specimens of Globorotalia multicamerata and $G$. pertenuis varies considerably. The species G. tumida s. str. does not occur.

2) The Globorotalia miocenica Zone is marked by abundance of the index species and G. exilis. The assemblage of planktonic foraminifers includes also Sphaeroidinella dehiscens, Globigerinoides conglobatus, G. ruber, G. trilobus sacculifer, G. trilobus trilobus, G. trilobus fistulosus, G. elongatus, G. obliquus extremus, Orbulina universa, Globorotalia dutertrei, G. crassaformis, G. pertenuis, G. hirsuta, G. pseudopima, G. pseudomiocenica, Globigerinella siphonifera, Pulleniatina obliquiloculata, Globorotaloides hexagonus,
Globigerina rubescens, G. bulloides, G. quinqueloba, $G$. megastoma, Globigerinita uvula, G. glutinata, Turborotalita iota. Globorotalia menardii and G. cultrata were found only in the very top of the zone.

Thus, representatives of the genus Sphaeroidinellopsis, Globorotalia margaritae, Globigerina nepenthes, Globoquadrina altispira, G. dehiscens, Globigerinoides obliquus do not pass the base of the Globorotalia miocenica Zone, and in the basal layers the last specimens of Globorotalia multicamerata disappear.

Thickness is 11 meters. Interval: from $366 \mathrm{~A}-4-6,31-$ $33 \mathrm{~cm}$, to $366 \mathrm{~A}-5$, CC.

Within the Globorotalia miocenica Zone the disappearance of Globigerinoides trilobus fistulosus takes place. This enables its subdivision into two parts. The lower part bears the name of the Globigerinoides trilobus fistulosus Subzone-from 366A-5-5, 61-63 cm to $366 \mathrm{~A}-5, \mathrm{CC}$; the upper part is called the Globorotalia exilis Subzone-from 366A-4-6, 31-33 cm to 366A-5-4, $61-63 \mathrm{~cm}$.

No Globorotalia tumida specimens were found in sediments of the zone concerned, as before;

3) The Globorotalia tosaensis Zone with Globorotalia crassaformis, G. crassaformis viola, G. hirsuta, G. pseudopima, $G$. dutertrei, $G$. inflata, left-coiling $G$. menardii and G. cultrata, Sphaeroidinella dehiscens, Globigerinoides conglobatus, G. ruber, G. sacculifer, Orbulina universa, Candeina nitida, Pulleniatina obliquiloculata, etc. Sporadic small specimens of the type zonal species were recognized only in the top of the zone. Rare specimens of Globorotalia tumida also occur. Thickness is 7.5 meters. Interval: from $366 \mathrm{~A}-4-1$, $60-62 \mathrm{~cm}$ to $366 \mathrm{~A}-4-5,30-32 \mathrm{~cm}$.

The thickness of Pliocene deposits is about 57 meters.

The Pliocene is conformably overlain by Quaternary deposits (the Globorotalia crassaformis viola Subzone).

Thus, on the Sierra Leone Rise an excellent section of calcareous sediments of the Neogene with abundant planktonic foraminifers occurs. Relatively small gaps occur at the boundary of the lower middle and middle upper Miocene.

\section{Cape Verde Basin}

Hole 367 penetrated Neogene turbidites which are composed of an alternation of yellowish and brown clays, silty and sandy clays, nanno oozes, and marls. Small and well-sorted planktonic foraminifers are accompanied by redeposited Cretaceous, Eocene, Oligocene, and Neogene species. Rare coring (four cores in the Neogene) and heterogenic character of microfauna prevent a determination of thickness of Neogene deposits.

The relationship of the Neogene with Paleogene and Quaternary sediments is obscure due to the gaps in coring. The thickness of the Neogene can be determined within 200-250 meters. The lower part of Neogene turbidites contains Globigerinoides trilobus, globorotalias from the Globorotalia praemenardii and $G$. fohsi groups (Core 367-6). The age of these turbidites is not older than middle Miocene. Higher in the section (Cores $367-5,-4,-3$ ) the turbidites are characterized by Globorotalia tumida, G. multicamerata, G. crassaformis, Sphaeroidinella dehiscens, Globigerinoides con- 
globatus, G. ruber, Pulleniatina obliquiloculata, etc. Their age is not older than Pliocene.

Planktonic foraminifers are accompanied by redeposited benthic foraminifers of different ecological habitats, including shallow-water Amphistegina, Ammonia beccarii, Elphidium crispium, E. macellum, etc.

\section{Cape Verde Rise}

The peculiarity of the Neogene section from Hole 368 is reflected in its lithological features, as well as in the micropaleontological characteristics. We failed to establish a direct contact of the lower Miocene with older sediments, as the lower Miocene is underlain by thick noncalcareous clays which are barren of fossils. It is quite possible that the uppermost clay layers belong to the Neogene.

According to lithological peculiarities, the Neogene deposits are divided into three members: The lower member is composed of greenish and gray slightly calcareous and noncalcareous clays and silty clays cyclically alternating with one another (Cores 368-18 and 368-17). The clays are lower Miocene age; the middle member consists of greenish gray marls and calcareous clays replaced upwards the section by pale gray nanno oozes (Cores 368-16 to 368-6). It encompasses a greater part of the Miocene; the upper part consists of pale gray, yellowish, and greenish nanno-foraminiferal oozes and marls, and belongs to the late Miocene and Pliocene (Cores 368-5 and 368-4).

The minimum thickness of the Neogene section is about 230 meters.

Lower Miocene deposits do not produce a zonal subdivision. The clays at the base of the section in general contain only pyritic casts of planktonic foraminifers-Globigerinoides sp., Globigerinita unicava, Globoquadrina altispira globosa (Cores 368-18 and 368-17). Higher in the section (Cores 368-16 and $368-15$ ) in the calcareous clays are rare tests of the most resistant species-Globorotaloides suteri, Globigerinita unicava, G. dissimilis, G. stainforthi, Globoquadrina altispira globosa, Globigerinoides sp., Globigerina aff. venezuelana, $G$. praebulloides. The minimum thickness of the lower Miocene sediments is 38 meters.

Middle Miocene deposits are somewhat richer in planktonic foraminifers. Their numbers and specific diversity increase upsection-Orbulina suturalis, Sphaeroidinellopsis seminulina, Globigerinoides trilobus, G. subquadratus, Globoquadrina altispira, G. dehiscens, G. langhiana, Globigerina bollii, Globorotaloides variabilis, and sporadic Globorotalia peripheroronda and $G$. peripheroacuta. Interval: from $368-11-2,37-39 \mathrm{~cm}$ to 368-14, CC.

In the top of the middle Miocene the quantity and diversity of foraminifers is only sufficient to identify the Globigerina nepenthes-Globorotalia siakensis Zone with these index species: Sphaeroidinellopsis subdehiscens, Globorotalia menardii, G. continuosa, G. lenguaensis, Globigerinoides bollii, G. trilobus, Globoquadrina dehiscens, Globigerinita glutinata, Globorotaloides variabilis. Interval: from 368-10, CC to $368-11-1$, 140$142 \mathrm{~cm}$.
The thickness of the middle Miocene is $\mathbf{4 4 . 5}$ meters. A common series of zonal subdivisions can be observed in the upper Miocene:

1) The Globorotalia continuosa Zone with the index species, Globorotalia menardii, G. lenguaensis, $G$. scitula, Orbulina universa, Globigerina nepenthes, $G$. bulloides, G. conglomerata, Globigerinoides bollii, G. trilobus, Sphaeroidinellopsis subdehiscens, Sph. seminulina, Globoquadrina dehiscens, G. altispira, Globigerinita glutinata, Globorotaloides variabilis. Thickness is 8 meters. Interval: from $368-9-4,62-64 \mathrm{~cm}$ to $368-10-2,72-74 \mathrm{~cm}$;

2) The Globorotalia acostaensis Zone with the index species, G. merotumida, G. menardii, G. scitula, Orbulina universa, Globigerina nepenthes, Globigerinoides obliquus obliquus, G. bollii, Sphaeroidinellopsis subdehiscens, Sph. seminulina, Globoquadrina dehiscens, Globigerinita uvula, etc. Thickness is 19 meters. Interval: from 368-7-4, 62-64 $\mathrm{cm}$, to $368-9-3,72-74 \mathrm{~cm}$;

3) The Globorotalia plesiotumida Zone is characterized by the index species, Globorotalia dutertrei, G. menardii, G. merotumida, G. acostaensis, G. scitula, G. hirsuta, Orbulina universa, Globigerina nepenthes, G. bulloides, Globigerinoides obliquus obliquus, G. obliquus extremus, G. bollii, G. trilobus, Sphaeroidinellopsis subdehiscens, Sph. seminulina, Globoquadrina altispira, $G$. dehiscens, Globigerinita glutinata. Thickness is 5 meters. Interval: from 368-6, $\mathrm{CC}$ to $368-7-3,62-64 \mathrm{~cm}$;

4) The Globorotalia margaritae margaritae Zone. The assemblage of planktonic foraminifers consists of the index species, Globorotalia multicamerata, $G$. humerosa, G. pseudomiocenica, G. tumida, Globigerinoides parkerae, Sphaeroidinellopsis sphaeroides, Pulleniatina primalis, and rare specimens of Globigerinoides conglobatus, G. sacculifer, and Globorotalia crassaformis. These are accompanied by almost all of the species from underlying sediments of the Globorotalia plesiotumida Zone. The minimal thickness is 47 meters. Interval: from $368-5-1,62-64 \mathrm{~cm}$ to $368-6-6,62$ $64 \mathrm{~cm}$.

Only one core was taken in Pliocene deposits. Its lower part belongs to the Globorotalia margaritae evoluta Zone and includes the index species, $G$. pseudomiocenica, G. multicamerata, G. exilis, $G$. crassaformis, G. dutertrei, G. tumida, G. humerosa, Sphaeroidinella dehiscens, Globigerinoides conglobatus, G. obliquus extremus, G. sacculifer, G. ruber, Globoquadrina altispira, Sphaeroidinellopsis subdehiscens, Orbulina universa; Globorotalia miocenica appears here. Interval: from 368-4-2, 62-64 cm to 368-4, CC. The Pliocene is divided from the upper Miocene by a 28.5-meter uncored interval. This interval probably corresponds to the Globorotalia margaritae evoluta Zone.

In nanno-foraminifer oozes of the upper part of Core 368-4 Globorotalia miocenica and $G$. exilis are abundant, whereas representatives of Sphaeroidinellopsis, Globorotalia margaritae, Globoquadrina altispira are absent. This suggests that the sediments belong to the Globorotalia miocenica Zone. Sample location: 3684-1, $62-64 \mathrm{~cm}$. 
Another uncored interval (28.5 meters) separates the Pliocene from early Quaternary deposits (Globorotalia crassaformis viola Subzone). Sedimentation at the Pliocene and Quaternary boundary was quite likely continuous.

The character of alterations in the sediments (from clayey to calcareous) and planktonic foraminifers (from pyritic casts to rich assemblages) along the Neogene section in Hole 368 suggests a significant change of the sedimentation depth. At the Miocene-Paleogene boundary the sediments accumulated below the carbonate compensation depth (CCD). At the base of the lower Miocene appear casts of planktonic foraminifers, and in its upper part are associations of resistant species. In the middle Miocene the species composition of planktonic foraminifers is impoverished, because many species have been destroyed by selective dissolution. In the upper Miocene planktonic foraminifers are diverse, but their abundance in nanno oozes is relatively small. Since the beginning of the Pliocene, nanno foraminiferal oozes contain abundant and diverse planktonic foraminifers. The above changes of sediments and microfauna may be due to tectonic motion of the Cape Verde Rise region throughout the Miocene time or change in the CCD. The amplitude of these motions can be estimated roughly as up to 1500 meters.

\section{Spanish Sahara Continental Slope}

On the continental slope off Spanish Sahara Holes 369 and 369A penetrated monotonous calcareous pelagic sediments of Neogene age, 164 meters thick. The Neogene seems to be related to the Oligocene by a gradual transition, or separated by a small gap; the Globorotalia kugleri s. str. Zone has not been established here, but this may be associated with paucity of the fauna in this interval. The lower Miocene is composed of olive-gray and yellowish siliceous nanno oozes with a high content of radiolarians and diatoms. Planktonic foraminifers are not numerous. The upper part of the lower Miocene, middle and upper Miocene and Pliocene are presented by pale gray and greenish gray nanno oozes and nanno marls with abundant planktonic foraminifers.

The lower Miocene contains:

1) The Globigerinoides primordius-Globorotalia kugleri Zone with a poor microfauna. Besides the zonal species, there are Globorotalia siakensis, G. nana, Globigerina praebulloides, G. angustiumbilicata, G. venezuelana, G. juvenilis, G. aff. ciperoensis, Cassigerinella chipolensis, Globorotaloides suteri, Globigerinita unicava, $G$. dissimilis, Globoquadrina altispira globosa. In the top of the zone appear rare Globigerinoides trilobus and G. altiaperturus. Thickness is 9.5 meters. Interval: from 369A-13-1, 62-64 cm to 369A-13, $\mathrm{CC}$;

2) The Globigerina dissimilis Zone with the index species, Globigerinoides trilobus, G. altiaperturus, Globigerina venezuelana, G. juvenilis, G. angustiumbilicata, G. praebulloides, G. binaiensis, Globigerinita unicava, G. stainforthi, Globoquadrina praedehiscens, G. altispira, G. altispira globosa, Globorotalia siakensis. Thickness is 9.5 meters. Interval: from $369 \mathrm{~A}-12-1,62-64 \mathrm{~cm}$, to 369A-12, CC;
3) The Globigerinita stainforthi Zone with a similar assemblage of planktonic foraminifers, among which sporadic Globoquadrina dehiscens occur. Occurrence 369A-11, CC.

There are practically no deposits of the Globigerinita stainforthi Zone and the Globigerinatella insuetaGlobigerinoides trilobus Zone in the section, as upsection occur sediments of the uppermost part of the lower Miocene.

4) The Praeorbulina glomerosa Zone. Its assemblage of abundant planktonic foraminifers contains the index species, Praeorbulina transitoria, Globigerinoides bisphaericus, G. trilobus, G. subquadratus, G. diminutus, Sphaeroidinellopsis seminulina, Globigerina bollii, $G$. foliata, G. conglomerata, G. falconensis, Cassigerinella chipolensis, Globoquadrina dehiscens, G. altispira, G. altispira globosa, Globorotalia obesa, G. peripheroronda, G. siakensis, G. scitula, Globorotaloides suteri, Globigerinita unicava; in the top of the zone Globigerina druryi, Globorotalia archaeomenardii, and G. continuosa occur. Thickness is 47.5 meters. Interval: from 369A-7$1,62-64 \mathrm{~cm}$ to $369 \mathrm{~A}-11-6,62-64 \mathrm{~cm}$.

The thickness of the lower Miocene is 66.5 meters.

Middle Miocene deposits are related to lower Miocene deposits by a gradual transition and are subdivided into the following zones:

1) The Orbulina suturalis-Globorotalia peripheroronda Zone with abundant planktonic foraminifers-zonal species: Globorotalia praemenardii, G. archaeomenardii, G. obesa, G. siakensis, G. scitula, Globigerinoides trilobus, Globoquadrina dehiscens, $G$. altispira, G. altispira globosa, Sphaeroidinellopsis seminulina, Globigerina foliata, G. juvenilis, G. druryi, Globigerinita glutinata. In this zone is the final existence of Globigerinoides bisphaericus, Praeorbulina glomerosa, $P$. transitoria. Thickness is 14.5 meters. Interval: from $369 \mathrm{~A}-5-4,62-64 \mathrm{~cm}$ to $369 \mathrm{~A}-6, \mathrm{CC}$;

2) The Globorotalia peripheroacuta Zone with numerous specimens of the zonal species, G. praemenardii, G. archaeomenardii, Orbulina suturalis, Biorbulina bilobata; Globigerinoides bollii, G. obliquus obliquus appear for the first time. The main background of the planktonic foraminifer assemblage form species of Globorotalia, Globoquadrina, Globigerina, Globigerinita, Sphaeroidinellopsis typical for the basal layers of the middle Miocene. Thickness is 14 meters. Interval: from $369 \mathrm{~A}-4-1,62-64 \mathrm{~cm}$ to $369 \mathrm{~A}-5-3,63-65$ $\mathrm{cm}$;

3) The Globorotalia fohsi fohsi Zone defined by the appearance of the zonal species together with Globigerinoides ex gr. ruber and Globorotalia aff. cultrata. The assemblage of planktonic foraminifers is similar to that of the underlying Globorotalia peripheroacuta Zone. Among the common elements of this assemblage are Globorotalia peripheroronda, $G$. peripheroacuta, $G$. siakensis, $G$. praemenardii, $G$. archaeomenardii, G. continuosa, Orbulina suturalis, Globigerina druryi, Globigerinoides bollii, G. obliquus obliquus, etc. Thickness is 9.5 meters. Interval: from $369 \mathrm{~A}-3-1,62-64 \mathrm{~cm}$ to $369 \mathrm{~A}-3, \mathrm{CC}$.

The age determination of deposits in Cores 369A-1 and $369 \mathrm{~A}-2$ is difficult. The assemblage of planktonic foraminifers consists chiefly of middle Miocene 
species-Globorotalia fohsi lobata, G. praemenardii, G. siakensis, G. continuosa, Orbulina suturalis, Biorbulina bilobata, Globigerina druryi, Globigerinopsis aguasayensis combined with numerous transitional species. Yet, upper Miocene species of planktonic foraminifers were found together with themGloborotalia merotumida, G. plesiotumida, $G$. margaritae margaritae, Globigerinoides obliquus extremus, Candeina nitida praenitida, Globigerina nepenthes. The heterogeneous composition of the microfauna can be explained by two ways: redeposition of middle Miocene foraminifers into younger sediments of the upper Miocene and/or mechanical decomposition and mixing of sediments in the process of drilling along with uphole contamination. The latter assumption seems quite probable, since coring of Hole $369 \mathrm{~A}$ began at a depth of 42 meters. Thus, the sediments could be middle Miocene. This suggestion conforms with the data on radiolarians which suggest that the deposits belong to the middle Miocene Dorcadospyris alata and Cannartus petterssoni zones (Johnson, this volume). On the contrary, the data on nannoplankton testify to a much younger Pliocene age-the Discoaster asymmetricus-Reticulofenestra pseudoumbilica zones (Cepek, this volume).

The upper horizons of the section were penetrated by Hole 369. They belong to the upper Miocene and Pliocene.

In Cores $369-5,-4,-3$, the foraminiferal assemblage consists of Globorotalia margaritae margaritae, $G$. aff. tumida, G. menardii, G. plesiotumida, G. dutertrei, G. acostaensis, Sphaeroidinellopsis sphaeroides, Sph. subdehiscens, Globigerina nepenthes, Globigerinoides obliquus extremus, G. bollii, Orbulina universa, Candeina nitida, etc. This suggests that the deposits belong to the Globorotalia margaritae margaritae Zone of late Miocene. Higher in the section, 369-1-2, $62-64 \mathrm{~cm}$ to 369-2, CC, Globorotalia margaritae evoluta appears in sediments which serves as evidence of the Pliocene zone. The heterogeneous character of the microfauna in Cores 369-1 to 369-5 results from drilling disturbance.

Lower Pliocene deposits are overlain unconformably by late Quaternary sediments (the Globigerina calida calida Subzone).

Thus, Holes 369 and 369A penetrate an almost continuous section of lower and middle Miocene, with only a small gap in the lower Miocene. However, the sequence of upper Miocene and Pliocene deposits is not complete stratigraphically. It is quite probable that lower Miocene clay sediments with abundant radiolarians and diatoms were deposited at somewhat greater depth than calcareous oozes of the middle and upper Miocene and Pliocene with rich assemblages of planktonic foraminifers.

\section{Deep Basin Off Morocco}

Neogene deep-water sediments of the Morocco Basin, up to 200 meters thick, were penetrated by Hole 370 with episodic coring. Only three cores occur within Neogene sediments. This gives only a general idea of the Neogene stratigraphy.

The lower Miocene includes marls and calcareous clays with abundant radiolarians, diatoms, and sponge spicules. Planktonic foraminifers are sporadic here-Globigerina venezuelana, Globorotaloides suteri, Globorotalia siakensis, Globoquadrina aff. dehiscens (Core 370-4).

The middle and upper Miocene are presented by a pile of turbidites-frequent alternation of clay nanno oozes, clays, siltstones, and sands. The heterogeneous microfauna consists of a mixture of Miocene and Paleogene foraminifers. In Core 369-3 the age of sediments is not older than the late middle Mioceneupper Miocene (by presence of Globigerina nepenthes). In Core 370-2 the sediments are not older than the late upper Miocene (by presence of Globorotalia dutertrei, G. humerosa, G. acostaensis, G. margaritae, Globigerinoides obliquus extremus, Sphaeroidinellopsis sphaeroides).

Quaternary deposits occur after a large uncored interval.

Stratigraphic correlation of Neogene deposits penetrated by Holes 366, 366 A, 367, 368, 369, 369A, and 370 , is shown in Figure 2.

\section{ZONAL STRATIGRAPHY AND GEOLOGICAL HISTORY OF NEOGENE}

Miocene and Pliocene calcareous sediments on the Sierra Leone Rise, the Cape Verde Rise, and on the continental slope off Spanish Sahara contain planktonic foraminiferal assemblages of tropical and subtropical habitats. Stratigraphic distribution resembles the picture that was known before for the tropical and subtropical belts of other regions of the Atlantic, Pacific, and Indian oceans (Tables 2, 3, 4). Some differences of the stratigraphic range are explained by contradictions in species concept as well as real irregularities in the stratigraphic distribution of species. Differentiation of biozones and epiboles of these species is of especial importance for stratigraphy.

The studied sections enable tracing of the lineages of evolution of Globorotalia peripheroronda-G. fohsi lobata, Globigerinoides bisphaericus-PraeorbulinaOrbulina universa, Globorotalia margaritae primitiva- $G$. margaritae evoluta. Sporadic specimens of Globorotalia tosaensis occur only in the top of the Pliocene, whereas the lineage of $G$. tosaensis-G. truncatulinoides was not observed.

On the Sierra Leone Rise, in the Globorotalia margaritae margaritae Zone, the species $G$. tumida was not observed. Rare specimens appear considerably later in the Globorotalia tosaensis Zone. However, northwards, in the region of the Cape Verde Islands (Hole 368), the appearance of $G$. tumida is confined to the Globorotalia margaritae margaritae Zone, which confirms similarity with the Globorotalia tumida Zone. Here, in upper Miocene deposits, there is a wellpronounced succession: Globorotalia merotumida- $G$. plesiotumida-G. tumida tumida, and later $-G$. tumida flexuosa.

A peculiar feature of the lower Miocene microfauna of the region is an almost complete absence of Globigerinatella insueta.

There is an irregular distribution of some species of planktonic foraminifers within stratigraphic intervals. 


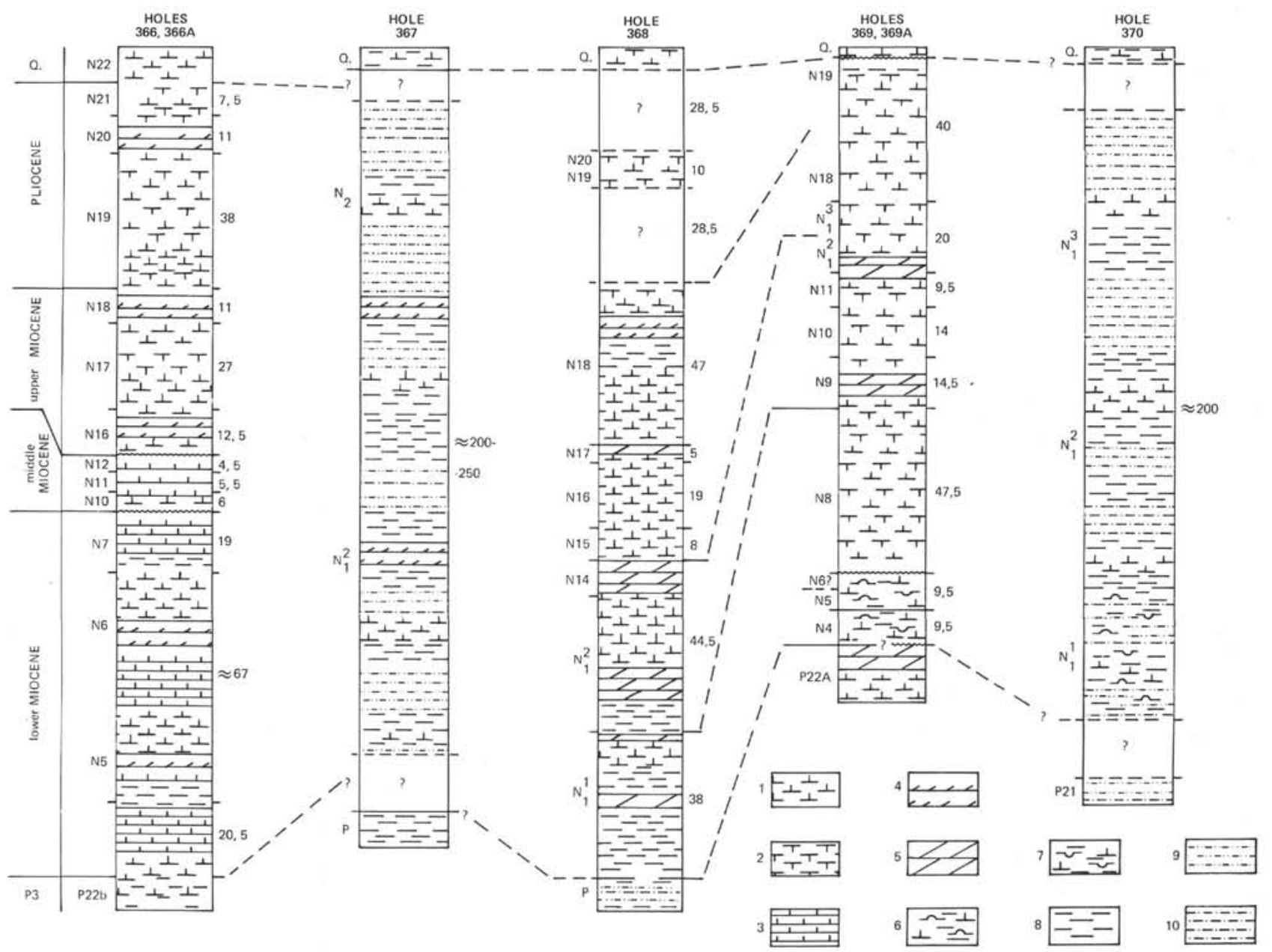

Figure 2. Stratigraphic correlation of Neogene deposits penetrated by Holes 366, 366 A, 367, 368, 369, 369A, and 370 . Lithological symbols: 1 - nanno oozes, 2 - foraminifer oozes, 3 - nanno chalk, 4 - nanno marls, 5 - marls, 6 - nanno clays with radiolarians, 7 - nanno clays with diatoms, 8 - clays, 9 - silty clays, 10 - sandy clays. Stratigraphic symbols: $P$ - Paleogene, $P_{3}$ - Oligocene, $N_{1}^{1}$ - lower Miocene, $N_{2}^{2}$ - middle Miocene, $N_{1}^{3}$ - upper Miocene, $N_{2}$ - Pliocene, $Q$ - Quaternary. Foraminiferal zones of Oligocene, Neogene and Quaternary: P21 - Globorotalia opima, $P 22 A$ - Globigerina ciperoensis, $P 22 b$ Globorotalia kugleri s. str.; N4 - Globigerinoides primordius - Globorotalia kugleri, N5 - Globigerinita dissimilis, N6 - Globigerinita stainforthi, $N 7$ - Globigerinatella insueta - Globigerinoides trilobus, $N 8$ - Praeorbulina glomerosa, $N 9$ - Orbulina suturalis - Globorotalia peripheroronda, N10 - Globorotalia peripheroacuta, N11 - Globorotalia fohsi fohsi, N12 - Globorotalia fohsi lobata, N14 - Globigerina nepenthes - Globorotalia siakensis, N15 - Globorotalia continuosa, N16 - Globorotalia acostaensis, $N 17$ - Globorotalia plesiotumida, $N 18$ - Globorotalia margaritae margaritae, $N 19$ - Globorotalia margaritae evoluta, $N 20$ - Globorotalia miocenica, $N 21$ - Globorotalia tosaensis, $N 22$ - Globorotalia truncatulinoides. Thickness is given in meters. When boundaries between adjacent zones are indistinct, thickness is given for stratigraphic subdivisions of the higher rank.

The intervals of Globorotalia menardii, G. cultrata, $G$. margaritae s.l., G. multicamerata, Sphaeroidinella dihiscens, Globigerina nepenthes are the same as in other regions of the world. Within these stratigraphic intervals, however, there are periods where these species are entirely absent in foraminifer assemblages and reappear in younger sediments.

There are some zonal schemes for subdivision of Neogene deposits of the tropical and subtropical areas (Bolli, 1957, 1959, 1966; Blow, 1969; etc.). They reflect the same succession of the planktonic foraminifer assemblages and differences between them have a rather methodical, and sometimes even formal, character (zone names). A similar succession of planktonic foraminifer assemblages occurs in Leg 41 deposits hence we can use the given zonal schemes for subdivision of the Neogene. At the same time, absence of some species, reduced intervals of distribution of other species (epibols), and irregularities in distribution of some species of planktonic foraminifers suggest that only zonal units, which are defined by an assemblage of planktonic foraminifers, are reliably valid. The composition of foraminifers of this assemblage varies, depending on ecological and climatic peculiarities. Yet, there are always species that substitute one another and enable dating of sediments to a certain zone. In these cases the question of definition of a zone becomes formal, for instance, the Globorotalia tumida Zone, or the Globorotalia margaritae margaritae Zone, and requires mutual agreement. 
For the subdivision of Neogene deposits penetrated by Holes 366, 366A, 369, and 369A the zonal scale was a combination of the above-mentioned zonal scales. It includes:

Lower Miocene: the Globigerinoides primordiusGloborotalia kugleri Zone (Holes 366, 366A, 369A), the Globigerinita dissimilis Zone (Hole 366A, 369A), the Globigerinita stainforthi Zone (Hole 369A), the Globigerinatella insueta-Globigerinoides trilobus Zone (Hole 366A), the Praeorbulina glomerosa Zone (Hole 369A);

Middle Miocene: the Orbulina suturalis-Globorotalia peripheroronda Zone (Hole 369A), the Globorotalia peripheroacuta Zone (Holes 366A, 369A), the Globorotalia fohsi fohsi Zone (Holes 366A and 369A), the Globorotalia fohsi lobata Zone (Hole 366A), the Globigerina nepenthes-Globorotalia siakensis Zone (Hole 368);

Upper Miocene: the Globorotalia continuosa Zone (Hole 368), the Globorotalia acostaensis Zone (Holes $366,366 \mathrm{~A}, 368)$, the Globorotalia plesiotumida Zone (Holes 366A, 368), the Globorotalia margaritae margaritae Zone (Holes 366A, 368);

Pliocene: the Globorotalia margaritae evoluta Zone (Holes 366A, 368); the Globorotalia miocenica Zone (Holes 366A, 368) with two Subzones-Globigerinoides trilobus fistulosus (Hole 366A) and Globorotalia exilis (366A); Globorotalia tosaensis Zone (Hole 366A).

In Hole 369A the Globigerina stainforthi Zone was distinguished conditionally, and in Hole $366 \mathrm{~A}$ it was united with the Globigerinita dissimilis because of absence of Globigerinatella insueta. In any case, the assemblages of planktonic foraminifers of these two zones are very similar indeed.

The only zone lacking in the principal zonal scale of Neogene sediments off west Africa is the Sphaeroidinellopsis subdehiscens-Globigerina druryi Zone of the middle Miocene. This is due to a number of geological and paleontological reasons, such as a gap in Hole $366 \mathrm{~A}$ and poor microfauna in Hole 368.

A detailed stratigraphy enables us to restore the geological history of the Sierra Leone Rise, the Cape Verde Rise, and the continental slope off Spanish Sahara, but the rare coring and poor microfauna make such an analysis difficult for the Cape Verde basin and the Morocco basin.

On the Sierra Leone Rise and the continental slope off Spanish Sahara the lower Miocene is practically related with Oligocene by a gradual transition. Such a Neogene-Paleogene relation is quite probable on the Cape Verde Rise (when judged by a gradual substitution of clay sediments by calcareous ones). This contradicts the data on the Horseshoe abyssal Plain (Hole 135), the Madeira Island (Hole 136) and the continental slope southwest off the Cap Blanc (Hole 140) where the Miocene occurs unconformably on Upper Cretaceous and Eocene sediments.

A relatively quiet process of carbonate sedimentation was interrupted within the lower Miocene off Spanish Sahara, at the lower-middle, middle-upper Miocene boundaries on the Sierra Leone Rise. Such gaps are likely to exist in upper Miocene-Pliocene sediments of the continental slope off Spanish Sahara. The
Quaternary deposits unconformably overlie the lower Pliocene, whereas on the Sierra Leone Rise and on the Cape Verde Rise there is a gradual transition within Pliocene and Quaternary sediments.

The substitution of clay sediments by calcareous ones, and the change of the character of microfauna upwards the section on the Cape Verde Rise and the continental slope off Spanish Sahara suggest upwards vertical tectonic motions during Miocene time. These motions occurred in some regions of the eastern Atlantic on a background of general oceanic subsidence. Similar vertical motions were recorded previously north of the Maderia Island (Hole 136), where the Neogene section comprised more shallowwater sediments than underlying ones.

Neogene deposits of the Morocco basin and the Cape Verde Basin are characterized by a wide development of turbidites with a heterogenic microfauna. This appears to be related to the general intensification of the tectonic processes in the Neogene time.

\section{PALEONTOLOGICAL PART}

This part contains short comments on selected species of Miocene and Pliocene planktonic foraminifers touching on peculiarities of their morphology, stratigraphic distribution, frequency, etc. The figured specimens as well as negatives of scanning micrographs are deposited in the Geologisch-Paläontologisches Institut und Museum of the Kiel University.

\section{Genus GLOBIGERINA D'ORBIGNY, 1826}

\section{Globigerina nepenthes Todd \\ (Plate 1, Figures 1-3)}

Globigerina nepenthes Todd, 1957, p. 301, pl. 78, Fig. 7.

This species appears in the very top of the middle Miocene (the Globigerina nepenthes-Globorotalia siakensis Zone, Hole 368), common in sediments of late Miocene and early Pliocene age and does not cross the top of the Globorotalia margaritae evoluta Zone. The last chamber is characterized by low porosity, diameter of pores is about $4 \mu \mathrm{m}$; pores are progressively closed by crust material towards older chambers as well as towards umbilical area.

\section{Globigerina megastoma Earland \\ (Plate 1, Figure 4)}

Globigerina megastoma Earland, 1934; see Banner and Blow, 1960, p. 14 , pl. 1, fig. 2 .

First sporadic specimens of G. megastoma have been discovered in the top of the Globorotalia margaritae evoluta Zone, becoming more frequent in sediments of middle and late Pliocene.

The ultrastructure is marked by a quite regular pore pattern; the pores lie in the center of slight depressions which are surrounded by sharpened divides. The latter are connections of the spine bases forming a polygonal net on a merely smooth primary surface of the test. Spines are broken off, but their position is shown by open hollows.

\section{Globigerina bradyi Wiesner}

(Plate 1, Figures 5-7)

Globigerina sp. Brady, 1884 , p. 603 , pl. 82 , fig. 8,9 .

Globigerina bradyi Wiesner, 1901-1903, p. 133.

This high-spired species is typical for the lower part of the lower Miocene (the Globigerinoides primordius-Globorotalia kugleri and Globigerinita dissimilis Zones) and less developed in younger sediments. Its identity with recent $G$. bradyi requires confirmation.

The ultrastructure of the surface is rather smooth with numerous, well separated pustules and also numerous tiny pores (diameter 0.5 $\mu \mathrm{m})$. On the initial whorls, pustules are of the same size, but are closer arranged forming a loose crust. The ultrastructure resembles that of Globigerinita glutinata and Globigerina juvenilis. 
TABLE 2

Distribution and Abundance of Selected Planktonic Foraminifera of the Early and Middle Miocene Hole 369A,

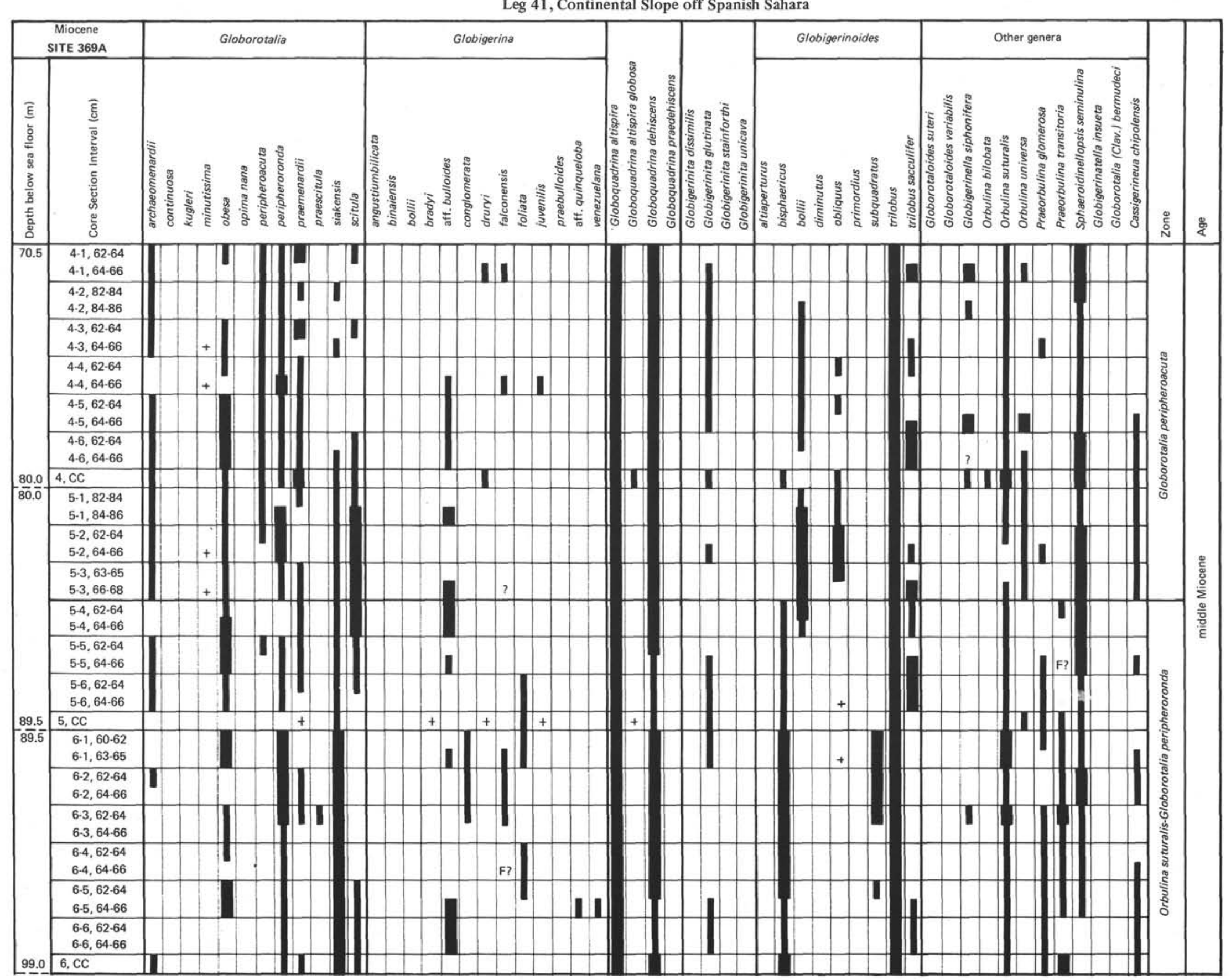




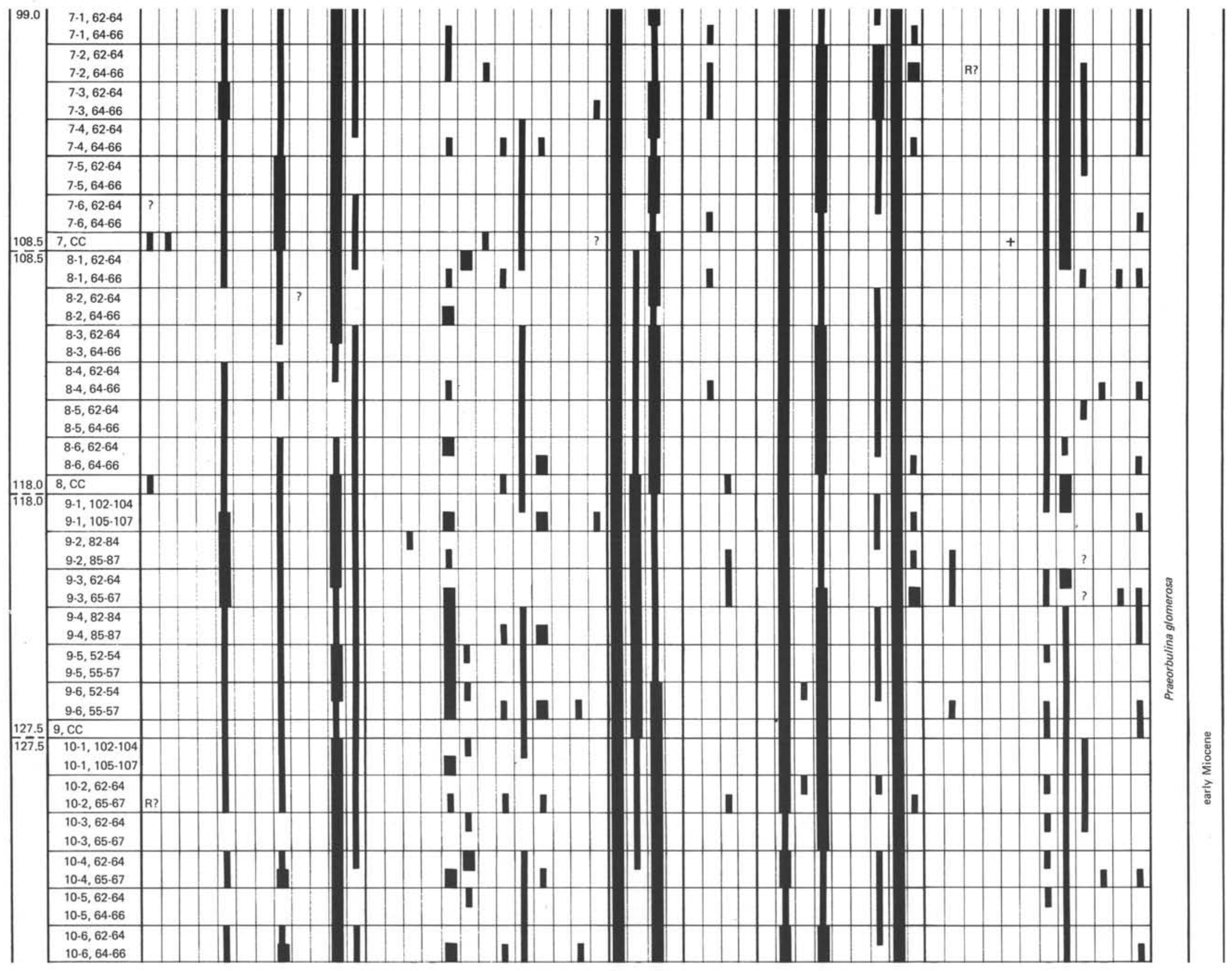


TABLE 2 - Continued

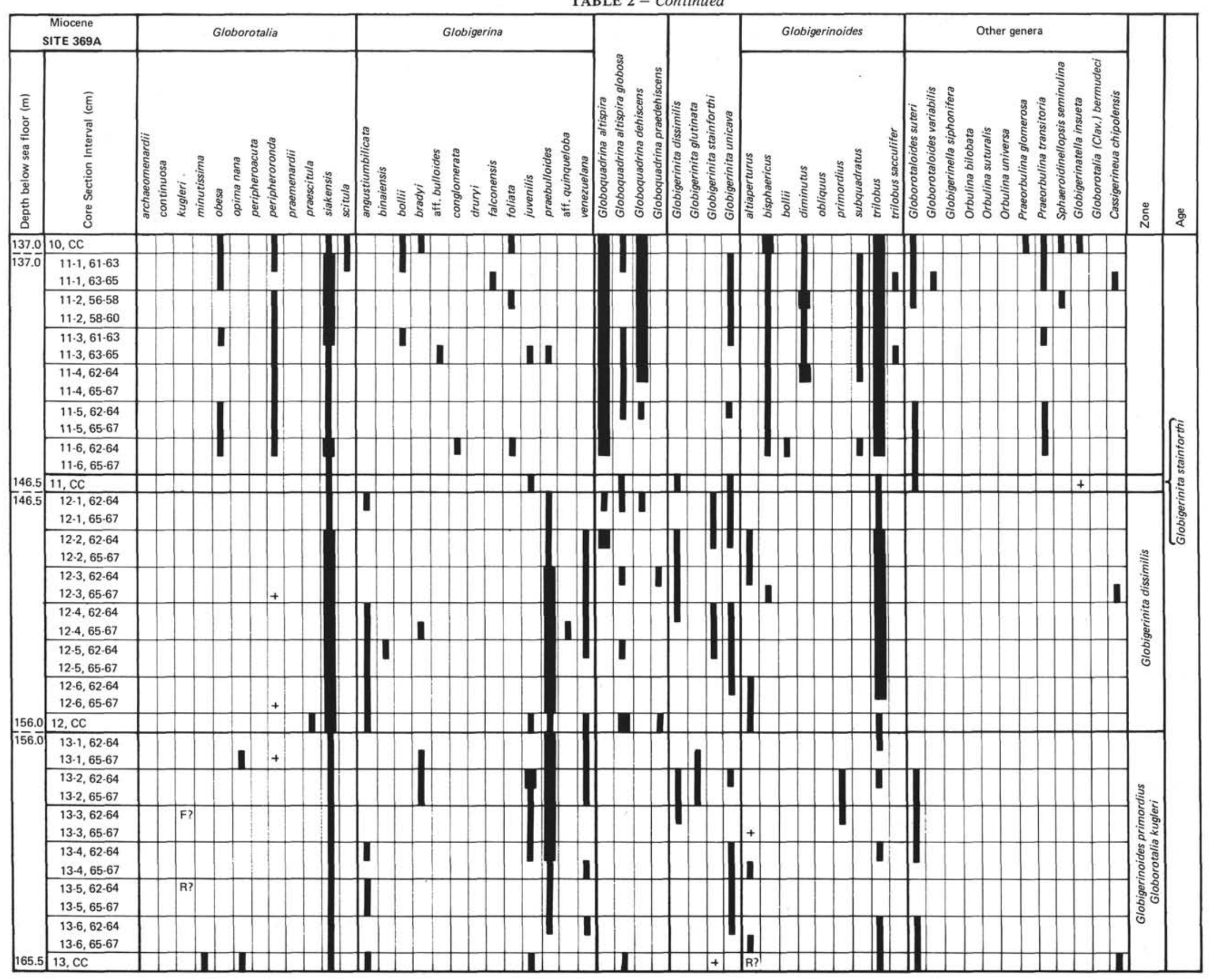




\section{Globigerina juvenilis Bolli}

(Plate 1, Figures 8,9)

Globigerina juvenilis Bolli, 1957, p. 110, pl. 24, fig. 5,6.

The species occurs over the whole Neogene interval, being most frequent in the lower Miocene sediments.

The main features of the ultrastructure are determined by abundant isolated pustules which are bigger in size on the spiral side of the chambers. Pores are numerous but very fine $(0.5 \mu \mathrm{m})$. No spines have been detected.

\section{Globigerina venezuelana Hedberg \\ (Plate 1, Figures 12-14)}

Globigerina venezuelana Hedberg, 1937, p. 681, pl. 92, fig. 7.

This species with four inflated chambers in the last whorl is common for the lower Miocene sediments. Similar forms are developed in deposits of younger age, but the species in question differs from them in tight arrangement of chambers which are narrow on the spiral side; the last chamber forms a lobe on the umbilical side. Therefore, middle and late Miocene and Pliocene specimens are usually attributed by us to $G$. conglomerata.

The ultrastructure is given by high porosity when big pores (diameter $7-10 \mu \mathrm{m}$ ) are separated by narrow partitions. The specimens figured show a quite coarse crystallinity of the wall. Spines or spine bases have not been encountered. Porosity of the umbilical area is less pronounced.

\section{Genus GLOBIGERINATELLA Cushman and Stainforth, 1945}

\section{Globigerinatella insueta Cushman and Stainforth} (Plate 1, Figures 10,11)

Globigerinatella insueta Cushman and Stainforth, 1945, p. 68, textfig.; Bolli, Loeblich, and Tappan, 1957, p. 38, pl. 8, fig. 4-7.

Extremely rare specimens of this species have been found in sediments of the Globigerinatella insueta-Globigerinoides trilobus Zone (Hole 366A) and the Praeorbulina glomerosa Zone (Hole 369A) of the lower Miocene.

The ultrastructure of the wall is presented by a smooth primary surface with a medium porosity (pore diameter up to $1 \mu \mathrm{m}$ ) and big cone-like isolated pustules. Multiple apertures are positioned on nonporous collar-like elevations partly covered by nonporous irregular bullas. In principle the ultrastructure of $G$. insueta is similar to that of modern Globigerinita (G. glutinata) and Globigerina bradyi and $G$. juvenilis.

\section{Genus GLOBOQUADRINA Finlay, 1947}

Globoquadrina altispira (Cushman and Jarvis)

$$
\text { (Plate 2, Figures 1-3) }
$$

Globigerina altispira Cushman and Jarvis, 1936, p. 5, pl. 1, fig. 1314.

This species is abundant in Miocene and lower Pliocene sediments and disappears in the top of the Globorotalia margaritae evoluta Zone.

The ultrastructure looks like a polygonal net consisting of big rounded pores (diameter up to $10 \mu \mathrm{m}$ ) subdivided by high narrow partitions. The arrangement of pores is very regular. Spines are absent. Sometimes there are high pustules in the umbilical area.

\section{Globoquadrina dehiscens (Chapman, Parr, and Collins)}

(Plate 2, Figure 4)

Globorotalia dehiscens Chapman, Parr, and Collins, 1934, p. 569, pl. 11 , fig. 36 .

Rare specimens of this species appear, evidently, in the Globigerinita stainforthi Zone (Hole 369A) of the lower Miocene; common for the upper part of the lower Miocene, as well as for middle and upper Miocene and lower Pliocene; it does not cross the base of the Globorotalia miocenica Zone (middle Pliocene).

The ultrastructure is very similar to that of Globoquadrina altispira, but interspaces between pores are higher and sharpened. In the area of the umbilicus and initial whorls of the spiral side crystal growth is strengthened closing pores.

\section{Genus GLOBIGERINOIDES Cushman, 1927}

Globigerinoides primordius Blow and Banner (Plate 2, Figures 5-10)

Globigerinoides quadrilobatus primordius Blow and Banner, 1962, p. 115 , pl. IX, fig. D-E.
The species has a very short stratigraphic interval, being limited to the Globigerinoides primordius-Globorotalia kugleri Zone of the lower Miocene (Holes 366A, 369A).

The ultrastructure is characterized by a high porosity (diameter of pores up to $8 \mu \mathrm{m}$ ). Divides have very steep flanges to rounded pores. Bases of broken spines are clearly visible, about 3 to 4 around one pore. Proximal parts of spines are rather thick (up to $5 \mu \mathrm{m}$ ).

\section{Globigerinoides altiaperturus Bolli}

(Plate 3, Figures 1-3)

Globigerinoides triloba altiapertura Bolli, 1957, p. 113, pl. 25, fig. 7,8 , text-fig. $21, \mathrm{~N} 3$.

Rare specimens of the species concerned appear in the Globigerinoides primordius-Globorotalia kugleri Zone; it is common for the next Globigerinita dissimilis Zone (lower Miocene).

The ultrastructure is like that of Globigerinoides primordius, but the quantity of spines near rounded pores seems to be reduced. Spines are located on the elevated parts of dividers.

\section{Globigerinoides subquadratus Bronnimann} (Plate 3, Figures 4-6)

Globigerinoides subquadratus Bronnimann, 1954, in Todd, Cloud, Low, and Schmidt, p. 680 , pl. 1, fig. 5.

Common for the Praeorbulina glomerosa Zone (lower Miocene) and middle Miocene sediments of the eastern Atlantic.

No significant difference against Globigerinoides altiaperturus and G. primordius in ultrastructure.

\section{Globigerinoides diminutus Bolli}

(Plate 3, Figures 7,8)

Globigerinoides diminutus Bolli, 1957, p. 114, pl. 25, fig. 11.

A very characteristic species for sediments of the upper part of the lower Miocene: the Globigerinatella insueta-Globigerinoides trilobus and Praeorbulina glomerosa Zones (Holes 366A and 369A).

The ultrastructure has many in common with that abovementioned species of Globigerinoides.

\section{Globigerinoides bollii Blow \\ (Plate 3, Figures 9-11)}

Globigerinoides bollii Blow, 1959, p. 189, pl. 10, fig. 65 .

This species appears in sediments of the Globorotalia peripheroacuta Zone (middle Miocene) and constitutes an essential element of microfauna of the middle and upper Miocene and lower Pliocene. Its last rare specimens have been encountered in the Globorotalia miocenica Zone (middle Pliocene).

The ultrastructure resembles that of other described species of Globigerinoides. Porosity in somewhat lower due to reduced pore diameters $(4-5 \mu \mathrm{m})$ and broader divides. On the spiral side initial whorls display reduced porosity seemingly on account of proceeding of crystal growth.

\section{Globigerinoides obliquus obliquus Bolli}

(Plate 4, Figures 1-3)

Globigerinoides obliquus obliquus Bolli, 1957, p. 113, pl. 25, fig. 9-10.

This subspecies is widely developed in sediments of the middle and upper Miocene and Pliocene.

The type of ultrastructure is similar to that of $G$. bollii, $G$. diminutus, etc. (polygonal net of rounded pores and elevated dividers). But in the apertural area (Figure $3 \mathrm{~b}$ ) porosity is lower (diameter of pores is reduced and dividers are flat and broad) and pustules are common (sometimes with traces of broken spines).

\section{Globigerinoides obliquus extremus Bolli and Bermudez} (Plate 4, Figures 4-6)

Globigerinoides obliquus extremus Bolli and Bermudez, 1965, p. 159, pl. 1, fig. 10-12.

The subspecies appears in sediments of the Globorotalia plesiotumida Zone (upper Miocene) and common for overlying deposits of upper Miocene and Pliocene.

The ultrastructure is like in $G$. obliquus obliquus except the last chamber where porosity is reduced (pore diameters about $3 \mu \mathrm{m}$ ).

\section{Globigerinoides fistulosus (Schubert) \\ (Plate 4, Figures 7-9)}

Globigerina fistulosa Schubert, 1910, p. 323, fig. 2.

The stratigraphic interval of this species is confined to the upper part of the Globorotalia margaritae evoluta Zone and the lower half of 
TABLE 3

Distribution and Abundance of Selected Planktonic Foraminifera of the Middle and Late Miocene Hole 366A, Leg 41, Sierra Leone Rise

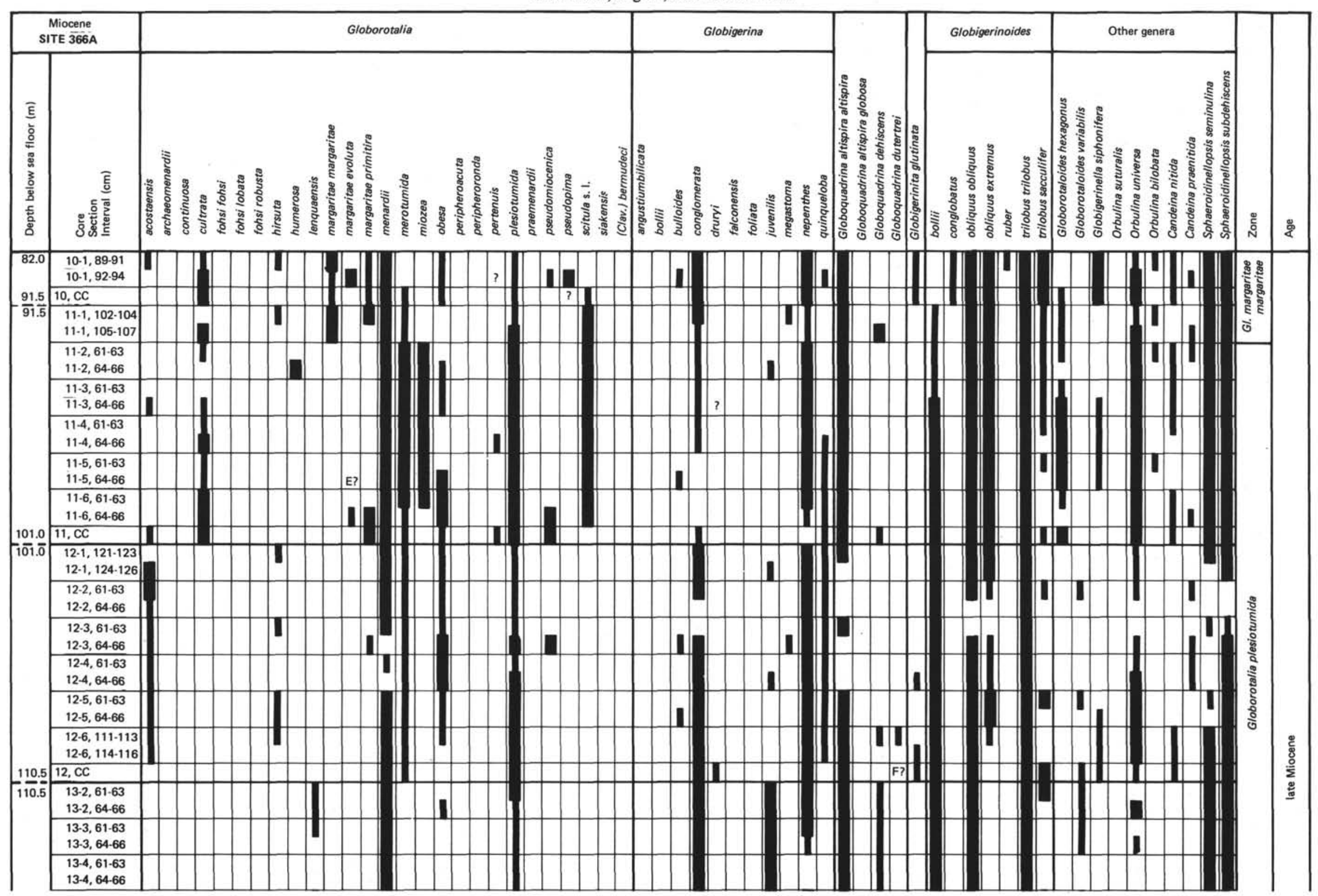




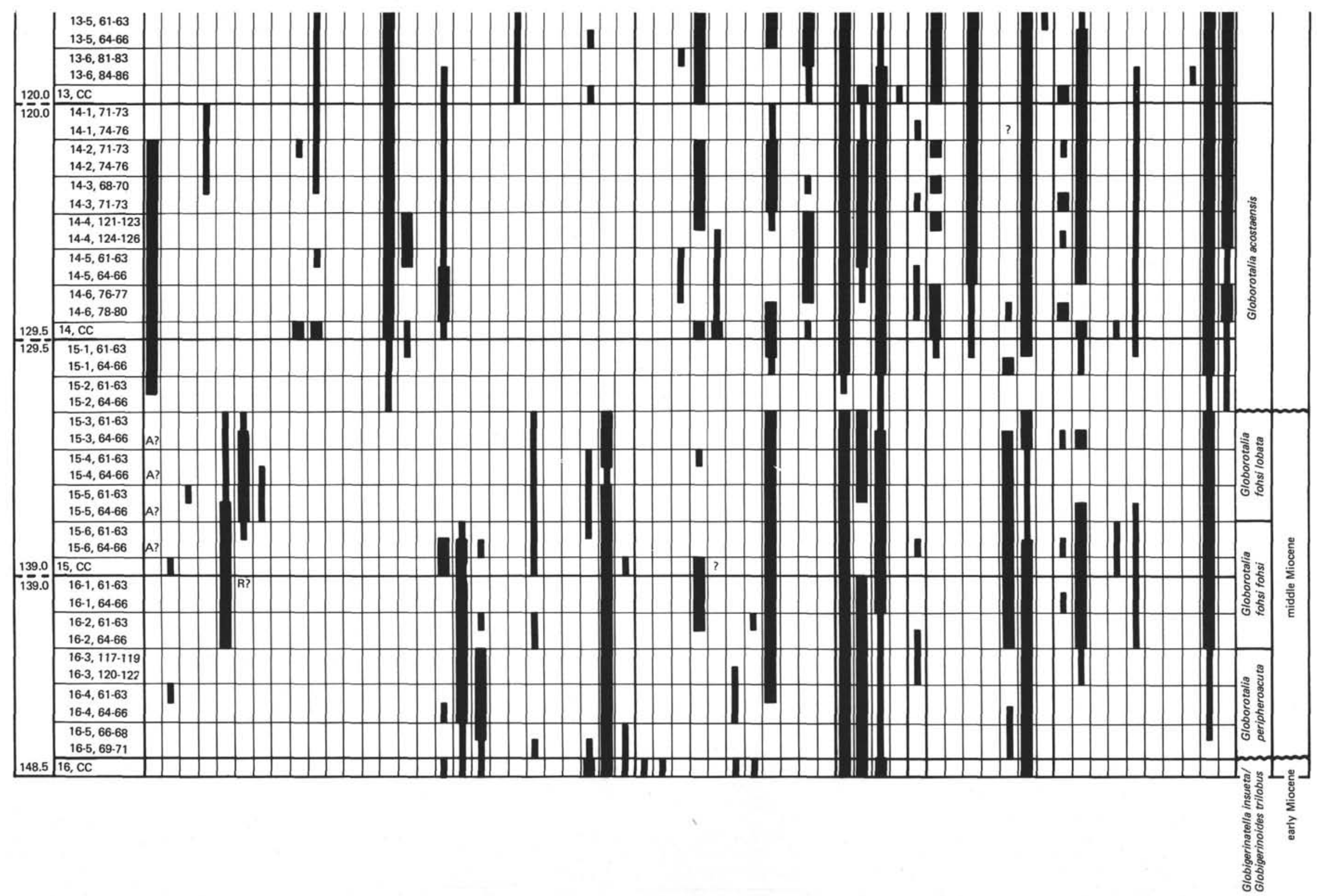


TABLE 4

Distribution and Abundance of Selected Planktonic Foraminifera of the Pliocene Hole 366A, Leg 41, Sierra Leone Rise

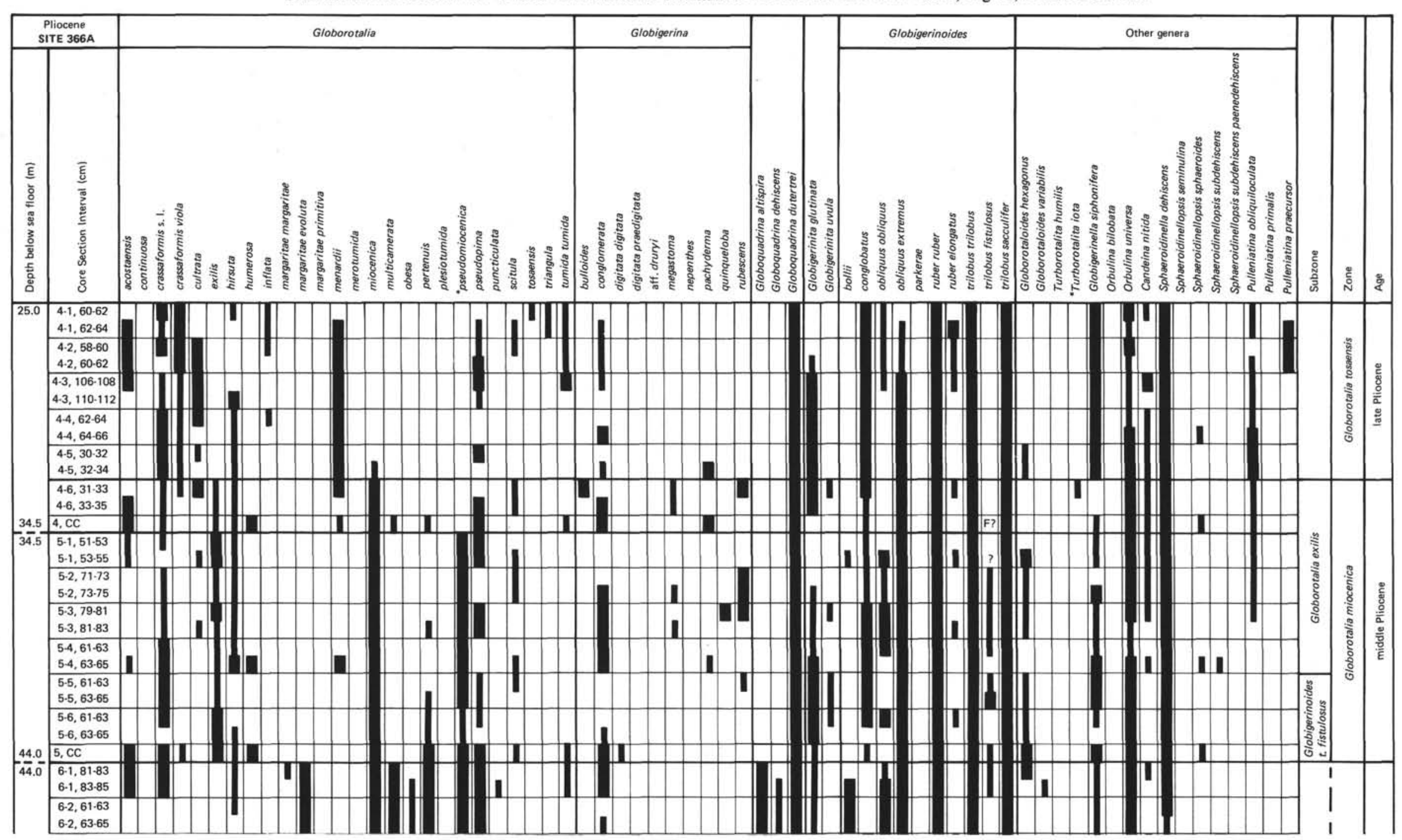




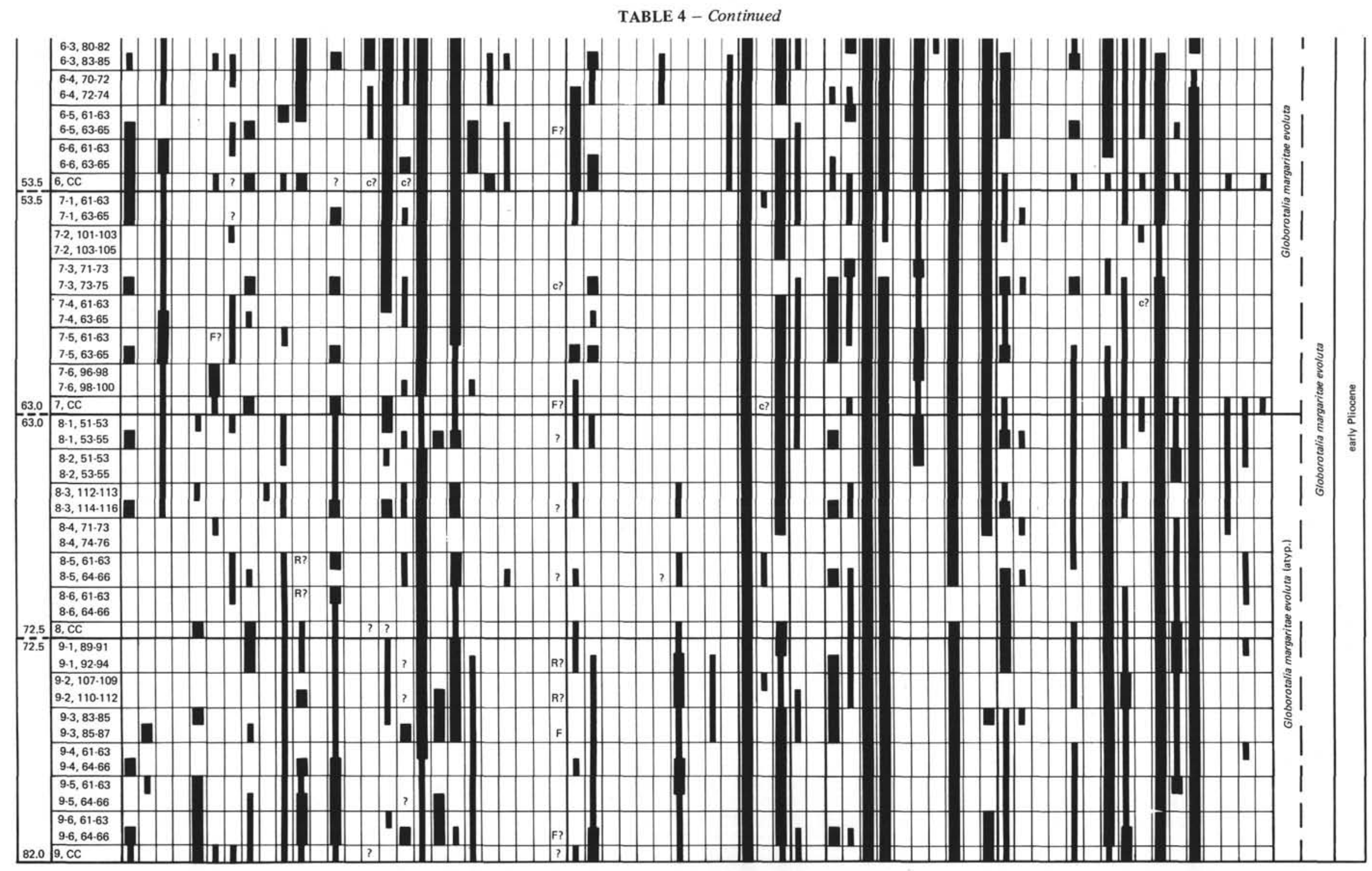

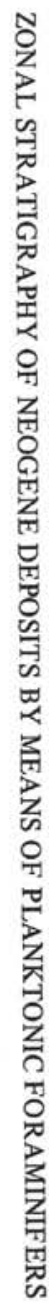


the Globorotalia miocenica Zone (Pliocene). Above this level only scattered specimens have been singled out.

The ultrastructure of this species belongs to that of the modern Globigerinoides trilobus group, which is characterized by high porosity due to large pore diameters (up to $10 \mu \mathrm{m}$ ) and by a polygonal net of sharpened divides. The edges of polygons are usually elevated and perforated by spines.

\section{Globigerinoides bisphaericus Todd \\ (Plate 5, Figures 1,2)}

Globigerinoides bisphaericus Todd, 1954, in Todd, Cloud, Low, and

Schmidt, p. 681 , pl. 1, fig. 1,4 .

Numerous specimens of this species are characteristic for sediments of the Praeorbulina glomerosa Zone (lower Miocene) continuing existence in the Orbulina suturalis-Globorotalia peripheroronda Zone (middle Miocene).

The ultrastructure is distinguished by large pores (diameters up to $15 \mu \mathrm{m}$ ) of rounded form and comparatively narrow high divides which are arranged to polygonal nets. At most elevated corners of dividers bases of broken spines are clearly seen. In general outlines the ultrastructure resembles that of the modern Globigerinoides tribolus group.

\section{Genus PRAEORBULINA Olsson, 1964}

\section{Praeorbulina glomerosa (Blow)}

(Plate 5, Figures 3-6)

Globigerinoides glomerosa, Blow, 1956, p. 64-65, text-fig. 1, N9-19, text-fig. 2, N1-5.

This species is widely developed in sediments of the Praeorbulina glomerosa Zone (lower Miocene)becoming less frequent in the next Orbulina suturalis-Globorotalia peripheroronda Zone (middle Miocene). All three subspecies have been encountered: $P$. glomerosa curva with clearly seen initial whorls and rare indistinct apertural openings (Figures 3,4); P. glomerosa glomerosa with a spherical test, highly embracing the last chamber and rather numerous small apertural openings along sutures (Figure 5) and $P$. glomerosa circularis with big numerous apertural openings encircling initial whorls (Figure 6).

\section{Praeorbulina transitoria (Blow)}

(Plate 6, Figures 1-3)

Globigerinoides transitoria Blow, 1956, p. 65, text-fig. 2, N12-15.

The species is the most typical for the Praeorbulina glomerosa Zone (lower Miocene) being less common for the Orbulina suturalisGloborotalia peripheroronda Zone (basal middle Miocene).

The ultrastructure of the species under consideration is determined by a polygonal net of divides with steep flanges and big circular pores (diameter up to $10 \mu \mathrm{m}$ ). Spines were apparently slender on account of small pointed bases of spines.

\section{Genus BIORBULINA Blow, 1956}

\section{Biorbulina bilobata (d'Orbigny)}

(Plate 6, Figures 4,5)

Globigerina bilobata d'Orbigny, 1846, p. 164, pl. 9, fig. 11-14.

This species appears at the base of the middle Miocene (the Orbulina suturalis-Globorotalia peripheroronda Zone) and goes through the middle-upper Miocene and Pliocene. But it is not abundant in the material of Leg 41 .

The ultrastructure of the penultimate chamber has a polygonal pattern like in Globigerinoides. The ultimate chamber is distinguished by comparatively low porosity. Rounded pores (diameter $4-5 \mu \mathrm{m}$ ) are separated by broad divides with a low relief. Sometimes the penultimate chamber shows feature of additional growing of calcite crystals which almost close pores.

\section{Genus ORBULINA d'Orbigny, 1839}

\section{Orbulina suturalis Bronnimann}

(Plate 6, Figures 6, 7)

Orbulina suturalis Bronnimann, 1951, p. 135, text-fig. 2, N1-2, 5-8, 10 , text-fig. $3, \mathrm{~N} 3-8,11,13-16,18,20-22$, text-fig. $4, \mathrm{~N} 2-4,7-12$, $15-16,19-22$.
This species determines the base of the middle Miocene (the Orbulina suturalis-Globorotalia peripheroronda Zone) and persists up to the present time. In materials of Leg 41 it is represented usually in a subordinate quantity of specimens.

The ultrastructure is characterized by a very indistinctly polygonal net of divides which separate circular pores (diameter 6-7 $\mu \mathrm{m})$. Many elevated and rounded bases of spines are located on the low dividers. Sometimes one pore is encircled by four to six spines. There are no special features of ultrastructure in the vicinity of multiple apertures.

\section{Orbulina universa d'Orbigny}

(Plate 6, Figures 8, 9)

Orbulina universa d'Orbigny, 1839 , p. 2, pl. 1, fig. 1.

Common for sediments of the middle-upper Miocene and Pliocene age.

The ultrastructure resembles that of $O$. suturalis (Figure $8 \mathrm{~b}$ ). In some specimens porosity is reduced and the quantity of spines around a pore is smaller. In contrast to recent orbulinas the ancient representatives of this genus display a picture of equidimensional pores.

Genus SPHAEROIDINELLOPSIS Banner and Blow, 1959

\section{Sphaeroidinellopsis sphaeroides Lamb \\ (Plate 7, Figures 1-3)}

Sphaeroidinellopsis sphaeroides Lamb, 1972, p. 60 , pl. 1, fig. 3-4, pl. 34 , fig. $3-8$, pl. 35 , fig. 1-7.

This species is developed in sediments of the Globorotalia margaritae margaritae Zone (the uppermost upper Miocene) and the Globorotalia margaritae evoluta Zone (lower Pliocene). Very rare and doubtful specimens of Sph. sphaeroides occur in higher horizons of Pliocene age.

The test is covered by a thick cortex which is protruded by broad openings on crater-like elevations. It is difficult to decide whether they belong to pores or broken spines.

\section{Sphaeroidinellopsis subdehiscens (Blow)}

(Plate 7, Figures 4-6)

Sphaeroidinella dehiscens subdehiscens Blow, 1959, p. 195, pl. 12, fig. 71-72.

This species appears at the very top of the middle Miocene (the Globigerina nepenthes-Globorotalina siakensis Zone, Hole 368) and common for sediments of the upper Miocene and lower Pliocene. Practically it disappears near the upper boundary of the Globorotalia margaritae evoluta Zone.

The test is covered by a cortex thickened on the earlier chambers and relatively thin on the peripheral part of the last chamber. Here the primary ultrastructure is yet visible. It is characterized by a polygonal net of slightly raised divides; in the centers of polygons there are crater-like openings which we interpret as pores in accordance with the Globigerinoides ultrastructure. On the corners of polygons there exist small openings indicating apparently position of broken spines.

\section{Sphaeroidinellopsis seminulina (Schwager)} (Plate 7, Figures 7-10)

Globigerina seminulina Schwager, 1866, p. 256, pl. 7, fig. 112.

This species appears in the Praeorbulina glomerosa Zone (lower Miocene) and abundant in sediments of the middle and upper Miocene as well as in the Globorotalia margaritae evoluta Zone (lower Pliocene). In the early part of the range of this species we encountered specimens with only 3 to $3-1 / 2$ chambers in the last whorl, which resemble Sph. subdehiscens.

The ultrastructure as given by Figure $7 \mathrm{~b}$ is in principle the same as in Sph. subdehiscens. The differences are reflected in larger pore openings and larger polygons.

\section{Genus PULLENIATINA Cushman, 1927}

\section{Pulleniatina primalis Banner and Blow} (Plate 7, Figures 11-14)

Pulleniatina primalis Banner and Blow, 1967, p. 142, pl. 1, fig. 3-8, pl. 3 , fig. 2 . 
Rare specimens of $P$. primalis have been discovered in sediments of the Globorotalia margaritae margaritae Zone (upper Miocene) and Globorotalia margaritae evoluta Zone (lower Pliocene).

The primary ultrastructure is marked by a thick cortex with a smooth surface. Remnants of pores are visible in form of branched slits. The umbilical area is covered by big pustules. The gentle relief of the cortex evidently reflects the polygonal primary ultrastructure.

\section{Genus GLOBOROTALIA Cushman, 1927}

\section{Globorotalia kugleri Bolli}

(Plate 8, Figures 1,2)

Globorotalia kugleri Bolli, 1957, p. 118, pl. 28, fig. 5,6.

Abundant in sediments of the Globigerinoides primordiusGloborotalia kugleri Zone of lower Miocene.

Circular and subcircular pores are surrounded by elevated rimlike dividers. In some places of intersection of divides there are small summits. Any indications of spines are absent.

\section{Globorotalia siakensis Le Roy}

(Plate 8, Figures 3-5)

Globorotalia siakensis Le Roy, 1939, p. 39, pl. 3, fig. 30-31.

This species is abundant in the lower and middle Miocene sediments, disappearing in the Globigerina nepenthes-Globorotalia siakensis Zone (Hole 368).

The ultrastructure is the same as that of $G$. kugleri, but rim-like divides are more elevated and summits are very obscure. There is no difference between the spiral and umbilical sides in respect of ultrastructure.

\section{Globorotalia acostaensis Blow}

(Plate 8, Figures 6-8)

Globorotalia acostaensis Blow, 1959, p. 208, pl. 17, fig. 106-107.

This species is very common in the upper Miocene sediments (the Globorotalia acostaensis and Globorotalia plesiotumida Zones) becoming less frequent in the uppermost upper Miocene and Pliocene.

The ultrastructure resembles those described for $G$. kugleri and $G$. siakensis but porosity is lower. Rounded pores are separated by broad divides with flattened surfaces.

\section{Globorotalia pseudopima Blow}

(Plate 8, Figures 9,10)

Globorotalia acostaensis pseudopima Blow, 1969, p. 387, pl. 35, fig. 1-7.

This species appears in the Globorotalia margaritae evoluta Zone but more frequent and typical for the higher horizons of Pliocene (the Globorotalia miocenica and Globorotalia tosaensis Zones).

The ultrastructure is defined by high porosity of the wall when circular pores with medium steep flanges are separated by thick rimlike divides with smoothened surface. Pores of the initial whorls on the spiral side and in the umbilical area are almost closed by heavy crystalline matter.

\section{Globorotalia peripheroronda Blow and Banner}

$$
\text { (Plate 9, Figures 12-14) }
$$

Globorotalia peripheroronda Blow and Banner, 1966, p. 294, pl. 1, fig. 1, pl. 2, fig. 1-3.

The stratigraphic interval of this species corresponds to the Globigerinita stainforthi Zone (lower Miocene)-the Globorotalia fohsi fohsi Zone (middle Miocene).

The ultrastructure is marked by comparatively low porosity with rounded and oval pores of different size (diameters 2-4 $\mu \mathrm{m}$ ) in random distribution on an even surface (Figure 12b). Porosity of the peripheral margin is of the same type (Figure 13b). A flap of the last chamber covering the umbilical area is nonporous, with small pustules. The initial whorls may be covered by a secondary calcite layer.

\section{Globorotalia peripheroacuta Blow and Banner}

$$
\text { (Plate 9, Figures 9-11) }
$$

Globorotalia peripheroacuta Blow and Banner, 1966, p. 294, pl. 1, fig. 2, pl. 2, fig. 4,5, 13 .

This species is developed in the Globorotalia peripheroacuta and Globorotalia fohsi fohsi zones of the middle Miocene.
The ultrastructure has many in common with that of $G$. peripheroronda, but porosity is higher due to larger pore diameters (from $3 \mu \mathrm{m}$ to $7 \mu \mathrm{m}$ ) and the distribution of pores is more regular following curved lines in radial direction (Figure 11b).

The peripheral margin of the initial chambers of the last whorl is rounded, perforated, with some rows of pores. Periphery of the last chambers is compressed, subacute, with a morphologically expressed rim. This rim has no pores on the surface, but in sections it is possible to see that its inner part is distinctly penetrated by pores (Figure 10b).

\section{Globorotalia fohsi fohsi Cushman and Ellisor}

(Plate 9, Figures 6-8)

Globorotalia fohsi fohsi Cushman and Ellisor, 1939, p. 12, pl. 2, fig. 6 .

This species is limited in its distribution by the Globorotalia fohsi fohsi and Globorotalia fohsi lobata zones of the middle Miocene.

The ultrastructure belongs to the type described above. Porosity is low, pore diameter is $3-4 \mu \mathrm{m}$ (Figure $8 \mathrm{~b}$ ). Peripheral margin is compressed on the last convolution and sharpened on the last chambers. In this part of the test the peripheral margin is keeled being in general poreless but with rare scattered pores (Figure 7b). Sutures are not limbate. In the umbilical area pustules are rather common forming pseudospines in the vicinity of the aperture.

\section{Globorotalia fohsi lobata Bermudez}

(Plate 9, Figures 1-5)

Globorotalia fohsi lobata Bermudez, 1949, p. 286, pl. 22, fig. 15-17.

This species was found in the middle Miocene.

The ultrastructure preserves that of the Globorotalia fohsi group. Porosity is high. Dividers are narrow, sometimes totally reduced at the surface producing elongated pores. Keel is well developed around the last whorl, nonperforate, composed of several layers. Sutures are distinctly limbate on the spiral side. Pustules in the umbilical area form pseudospines.

\section{Globorotalia miozea Finlay}

(Plate 10, Figures 13-15)

Globorotalia miozea Finlay, 1939, p. 326, pl. 29, fig. 159-161.

In sections investigated comparatively rare specimens of this species have been found in sediments of the Globorotalia plesiotumida and Globorotalia margaritae margaritae zones (upper Miocene).

Pores of different diameter (from $1 \mu \mathrm{m}$ to $4 \mu \mathrm{m}$ ) are randomly distributed on the almost even surface of the test (Figure 13b). The umbilical side of chambers (except the last one) is covered by pustules. The imperforate keel is clearly observed on the last chambers whereas the earlier ones have the rounded periphery with a poreless band.

\section{Globorotalia margaritae Bolli and Bermudez} (Plate 10, Figures 1-12)

Globorotalia margaritae Bolli and Bermudez, 1965, p. 139, pl. 1, fig. 16-18; Cita, 1973, p. 1352, pl. 1, fig. 1-7, pl. 2, fig. 1-3.

With this species three varieties with different stratigraphic intervals can be indentified.

The most ancient is $G$. margaritae primitiva $\mathrm{Cita}$ with a small, slightly elongated test; peripheral margin with a faint lobulation; periphery is subacute, without a real keel, but a poreless marginal band is very pronounced (Figures 10-12). The distribution is confined by the Globorotalia margaritae margaritae Zone (upper Miocene). The next variety $G$. margaritae margaritae Bolli and Bermudez, is characterized by a larger, compressed elongated test with a rapid increase of chamber height, clearly lobulate peripheral margin, distinctly imperforate keel, and limbate sutures (Figures 5-9). This variety starts in the upper Miocene and persists into the Globorotalia margaritae evoluta Zone, lower Pliocene.

The most advanced form Globorotalia margaritae evoluta Cita, is distinguished by its large test with circular (not elongated) outline, slow increase in height of the chambers, and almost symmetrical lenslike keeled test in peripheral view (Figures 1-3). This subspecies occurs in sediments of the Globorotalia margaritae evoluta Zone, lower Pliocene.

The ulstrastructures of $G$. margaritae primitiva, $G$. margaritae margaritae, and G. margaritae evoluta are quite similar; pores of different sizes penetrate an almost even surface of the test (diameter from $1 \mu \mathrm{m}$ to $4 \mu \mathrm{m}$ ). The porosity of the advanced $G$. margaritae evoluta is generally lower, pores being distributed more regularly and 
their sizes do not exceed $2 \mu \mathrm{m}$. In some primitive forms there are poreless sections of the wall in the posterior parts of chambers adjacent to the spiral suture and intercameral sutures (Figures 9a, $12 \mathrm{a})$. In case of $G$. margaritae primitiva pustules are restricted to the initial whorls, but they cover larger areas on the spiral side of $G$. margaritae margaritae and especially $G$. margaritae evoluta. The same trend can be observed on the umbilical sides. Pustules cover also the imperforate keel of $G$. margaritae margaritae and $G$. margaritae evoluta.

\section{Globorotalia pseudomiocenica Bolli and Bermudez} (Plate 11, Figures 1-3)

Globorotalia pseudomiocenica Bolli and Bermudez, 1965, p. 140, pl. 1, fig. 13-15.

Rare specimens of this species occur in the Globotalia plesiotumida Zone (upper Miocene). They are more numerous in sediments of the Globorotalia margaritae margaritae (upper Miocene) and Globorotalia margaritae evoluta (lower Pliocene) zones. In the Globorotalia miocenica Zone the species gradually disappears.

The ultrastructure is characterized by low porosity of the last chambers (Figure 16); pore diameters $0.5-2.0 \mu \mathrm{m}$; pores penetrate the smooth wall. In the beginning of the last whorl porosity is more pronounced. Big pustules are restricted to the umbilical area.

\section{Globorotalia plesiotumida Blow and Banner}

(Plate 11, Figures 4,5)

Globorotalia tumida plesiotumida Blow and Banner, 1965, p. 1353 , fig. 2 .

This species is very common for sediments of the Globorotalia plesiotumida and Globorotalia margaritae margaritae Zones (upper Miocene), disappearing in the base of the Globorotalia margaritae evoluta Zone (lower Pliocene).

The smooth wall is pierced by rounded pores of different diameters $(1-4 \mu \mathrm{m})$ in random distribution, performing medium porosity. Initial chambers of the last whorl on the umbilical side bear pustules extending to the peripheral margin and covering the keel.

\section{Globorotalia praemenardii Cushman and Stainforth}

(Plate 11, Figures 6-8)

Globorotalia praemenardii Cushman and Stainforth, 1945, p. 70, pl. 13, fig. 14 .

Rather common species for sediments of the Globorotalia peripheroacuta, Globorotalia fohsi fohsi, and Globorotalia fohsi lobata zones (middle Miocene). Rare specimens have been encountered in the basal layers of the middle Miocene (the Orbulina suturalisGloborotalia peripheroronda Zone).

\section{Globorotalia archaeomenardii Bolli}

$$
\text { (Plate 11, Figure 9) }
$$

Globorotalia archaeomenardii Bolli, 1957, p. 119, pl. 28, fig. 11.

Rare specimens of this species have been met in the lower Miocene sediments (upper part of the Praeorbulina glomerosa Zone), but it is more common for the middle Miocene interval (from the Orbulina suturalis-Globorotalia peripheroronda Zone up to the Globorotalia fohsi fohsi Zone).

The ultrastructure displays the high porosity; rounded and slightly elongated pores (diameter 3-4 $\mu \mathrm{m}$ ) are separated by faintly elevated divides forming a net of subrounded polygons (Figure 9d). The umbilical side is mostly covered by a coarse crystalline layer. Intercameral sutures are not limbate. The keel is well developed only on the last chambers (Figure 9e). In the beginning of the last whorl the peripheral margin is broadly rounded. Porosity is unknown because the periphery is covered by big crystals (Figure 9f).

Globorotalia (Clavatorella) bermudezi (Bolli) (Plate 11, Figure 10)

Hastigerinella bermudezi Bolli, 1957, p. 112, pl. 15, fig. 1 .

Rare specimens of this species are limited by the upper part of the Praeorbulina glomerosa Zone, lower Miocene, the Orbulina suturalisGloborotalia peripheroronda, and Globorotalia peripheroacuta zones, middle Miocene.

The ultrastructure is determined by a net of subrounded pores of very different sizes (from $2 \mu \mathrm{m}$ to $8 \mu \mathrm{m}$ in diameter); divides being narrow and elevated, with steep flanges. Spine pits were not observed.

\section{Globorotalia miocenica Palmer}

(Plate 12, Figures 1-3)

Globorotalia menardii miocenica Palmer, 1945, p. 70, pl. 1, fig. 10. This species appears in the top of the Globorotalia margaritae evoluta Zone being abundant in sediments of the Globorotalia miocenica Zone (Pliocene).

Porosity of the wall is of the medium type. Pores of different size (diameter from $2 \mu \mathrm{m}$ to $4 \mu \mathrm{m}$ ) are arranged irregularly or curved rows. They are located on the smooth wall. Pustules are restricted to the umbilical shoulders and are visible on the spiral keeled sutures. Keel and limbate intercameral sutures are well developed just from the very beginning.

\section{Globorotalia exilis Blow}

(Plate 12, Figures 4-6)

Globorotalia cultrata exilis Blow, 1969, p. 396, pl. 7, fig. 1-3, pl. 42, fig. 1,5 .

This species appears in the Globorotalia margaritae evolute Zone being abundant or common in sediments of the Globorotalia miocenica Zone, Pliocene.

The ultrastructure displays a fairly low porosity - the smooth microcrystalline wall is penetrated by tiny pores (diameter is below 1 $\mu \mathrm{m})$ comparatively regularly arranged, with large interspaces.

On both sides every younger chamber partly overlaps the proceeding one and hides limbate raised intercameral sutures on the spiral side (Figures 4,6a).

\section{Globorotalia pertenuis Beard \\ (Plate 12, Figures 7-9)}

Globorotalia pertenuis Bear, 1969, p. 552, pl. 1, fig. 1-6, pl. 2, fig. 5,6.

This species differs from G. multicamerata in less developed spiral suture and thinner wall. It is common for the Globorotalia margaritae evoluta Zone and the lower half of the Globorotalia miocenica Zone, Pliocene.

The fairly smooth granular wall is crossed by indistinct linear stripes and pierced by small pores of different sizes (diameter 1-2.5 $\mu \mathrm{m})$ with random pattern. Pustules are concentrated on the first chambers of the last whorl spreading to the keel.

\section{Globorotalia multicamerata Cushman and Jarvis}

(Plate 12, Figures 10-12)

Globorotalia menardii multicamerata Cushman and Jarvis, 1930, p. 367 , pl. 34 , fig. 8 .

This species with the thick keel and spiral suture has been determined in the Globorotalia margaritae margaritae Zone (upper Miocene) of Hole 368 but it is more common for the Globorotalia margaritae evoluta Zone, lower Pliocene.

The ultrastructure is characterized by minute comma-shaped or circular pores on a microgranular wall and wide interspaces between pores, resulting in low porosity of the umbilical side.

\section{ACKNOWLEDGMENTS}

The investigations of $\mathrm{U}$. Pflaumann were supported by the Deutsche Forschungsgemeinshaft.

\section{REFERENCES}

Blow, W.H., 1969. Late middle Eocene to Recent planktonic foraminiferal biostratigraphy: Int. Conf. Plankt. Microfossils, 1st, Proc.: Leiden (Brill), v. 1.

Bolli, H.M., 1957. Planktonic Foraminifera from the Oligocene-Miocene Ciperio and Lengua formations of Trinidad, B.W. I.: U.S. Nat. Museum, Bull, v. 215.

, 1959. Planktonic foraminifera as index fossils in Trinidad, West Indies and their value for worldwide stratigraphic correlation: Eclog. Geol. Helv., v. 52, no. 2. , 1966. Zonation of Cretaceous to Pliocene marine sediments based on planktonic Foraminifera: Bol. Inform. Asoc. Venez. Geol., Min., Petrol., v. 9, no. 1.

Hayes, D.E., Pimm, A.C., et al., 1972. Initial Reports of the Deep Sea Drilling Project, Volume 14: Washington (U.S. Government Printing Office). 
Maxwell, A., von Herzen, R., et al., 1970. Initial Reports of the Deep Sea Drilling Project, Volume 3: Washington (U.S. Government Printing Office).
Peterson, M., Edgar, N.T., et al., 1970. Initial Reports of the Deep Sea Drilling Project, Volume 2: Washington (U.S. Government Printing Office). 


\section{PLATE 1}

Figures 1-3 Globigerina nepenthes Todd.

Sample 366A-12, CC, late Miocene.

1a. Umbilical view, $\times 75$.

1b. Ultrastructure of the umbilical side of the last chamber, $\times 1000$.

2. Peripheral view, $\times 75$.

3. Spiral view, $\times 75$.

Figure $4 \quad$ Globigerina megastoma Earland.

Sample 366A-4-6, 31-33 cm, late Pliocene.

$4 a$. Umbilical view, $\times 150$.

$4 \mathrm{~b}$. Ultrastructure of the umbilical side of the penultimate chamber, $\times 1000$.

Figures 5-7 Globigerina bradyi Wiesner.

Sample 366A-12-4, 61-63 cm, late Miocene.

5. Spiral view, $\times 300$.

6. Peripheral view, $\times 300$.

7a. Umbilical view, $\times 300$.

$7 \mathrm{~b}$. Ultrastructure of the umbilical side of the last chamber, $\times 1000$.

Figures 8,9 Globigerina juvenilis Bolli.

Sample 366A-18-1, 61-63 cm, early Miocene.

8a. Spiral view, $\times 300$.

8 b. Ultrastructure of the spiral side of the last chamber, $\times 1000$.

8 c. Peripheral view, $\times 300$.

9a. Umbilical view, $\times 300$.

9b. Ultrastructure of the peripheral part of the last chamber, $\times 1000$.

Figures 10,11 Globigerinatella insueta Cushman and Stainforth. Sample 369A-9-4, 85-87 cm, early Miocene.

10a. Lateral view, $\times 150$.

10b. Ultrastructure of the area of the multiple apertures showing one of them, $\times 1000$.

11. Lateral view, $\times 150$.

Figures 12-14 Globigerina venezuelana Hedberg.

Sample 366A-21-4, 61-63 cm, early Miocene.

12. Spiral view, $\times 75$.

13. Umbilical view, $\times 75$.

14a. Spiral view, $\times 75$.

14b. Ultrastructure of the spiral side of the last chamber, $\times 1000$. 


\section{PLATE 1}

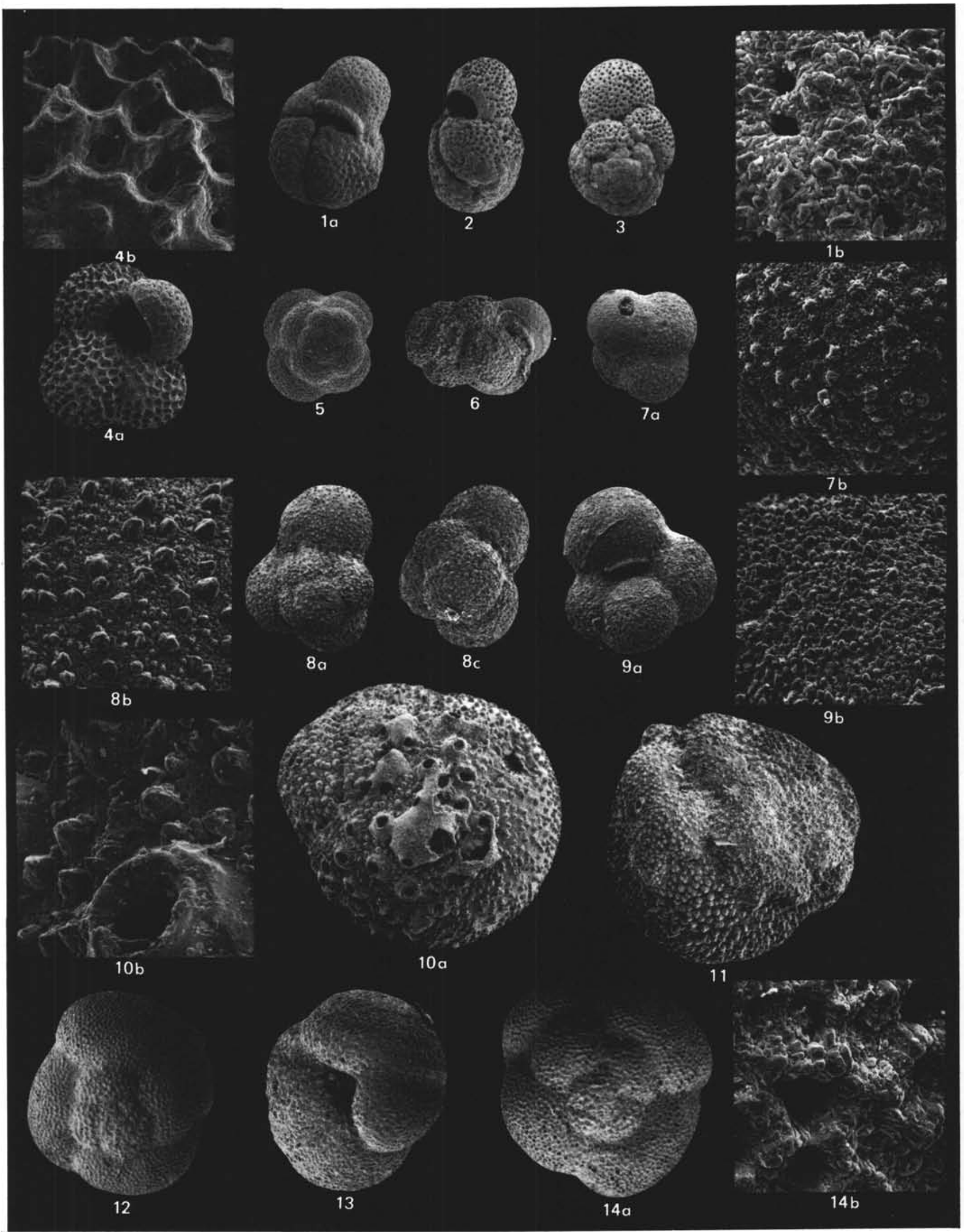




\section{PLATE 2}

Figures 1-3 Globoquadrina altispira (Cushman and Jarvis).

Sample 366A-6-2, 63-65 cm, early Pliocene.

1. Umbilical view, $\times 75$.

2. Peripheral view, $\times 75$.

3a. Spiral view, $\times 75$.

$3 \mathrm{~b}$. Ultrastructure of the spiral side of the last chamber, $\times 1000$.

Figure 4 Globoquadrina dehiscens (Chapman, Parr, and Collins).

Sample 366A-14-2, 71-73 cm, late Miocene.

4a. Umbilical view, $\times 75$.

4b. Peripheral view, $\times 75$.

4c. Spiral view, $\times 75$.

4d. Ultrastructure of the umbilical side of the last chamber, $\times 1000$

Figures 5-7 Globigerinoides primordius Blow and Banner.

Sample 366A-26, CC, early Miocene.

5. Umbilical view, $\times 150$.

6. Peripheral oblique view, $\times 150$.

7a. Spiral view, $\times 150$.

$7 \mathrm{~b}$. Ultrastructure of the spiral side of the last chamber, $\times 1000$.

Figures 8-10 Globigerinoides primordius Blow and Banner.

Sample 366A-26, CC, early Miocene.

8. Umbilical view, $\times 150$.

9. Peripheral view, $\times 150$.

10a. Spiral view, $\times 150$.

10b. Ultrastructure of the spiral side of the last chamber, $\times 1000$.

Note: specimens are transitional to Globigerinoides trilobus (Reuss). 


\section{PLATE 2}
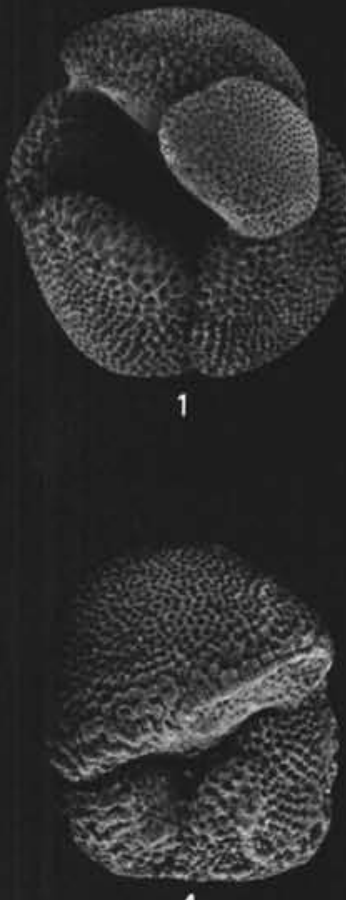

$4 a$

5

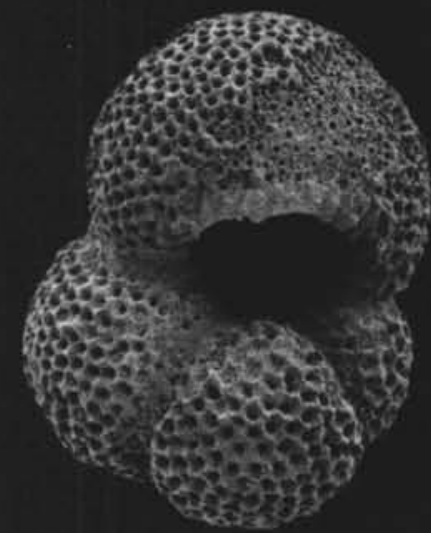

8

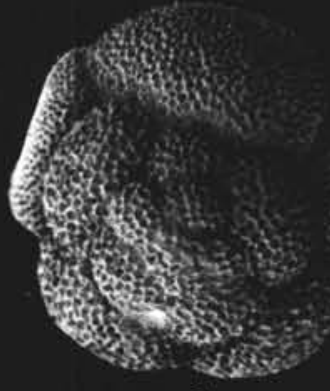

$3 a$

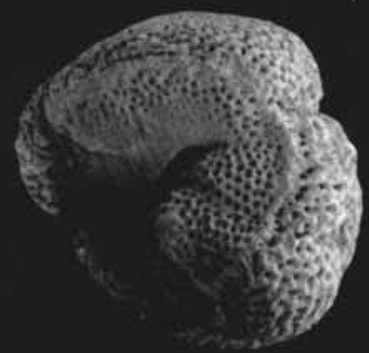

$4 b$

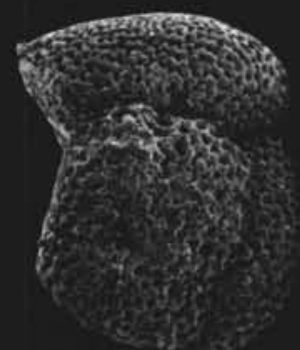

$4 c$
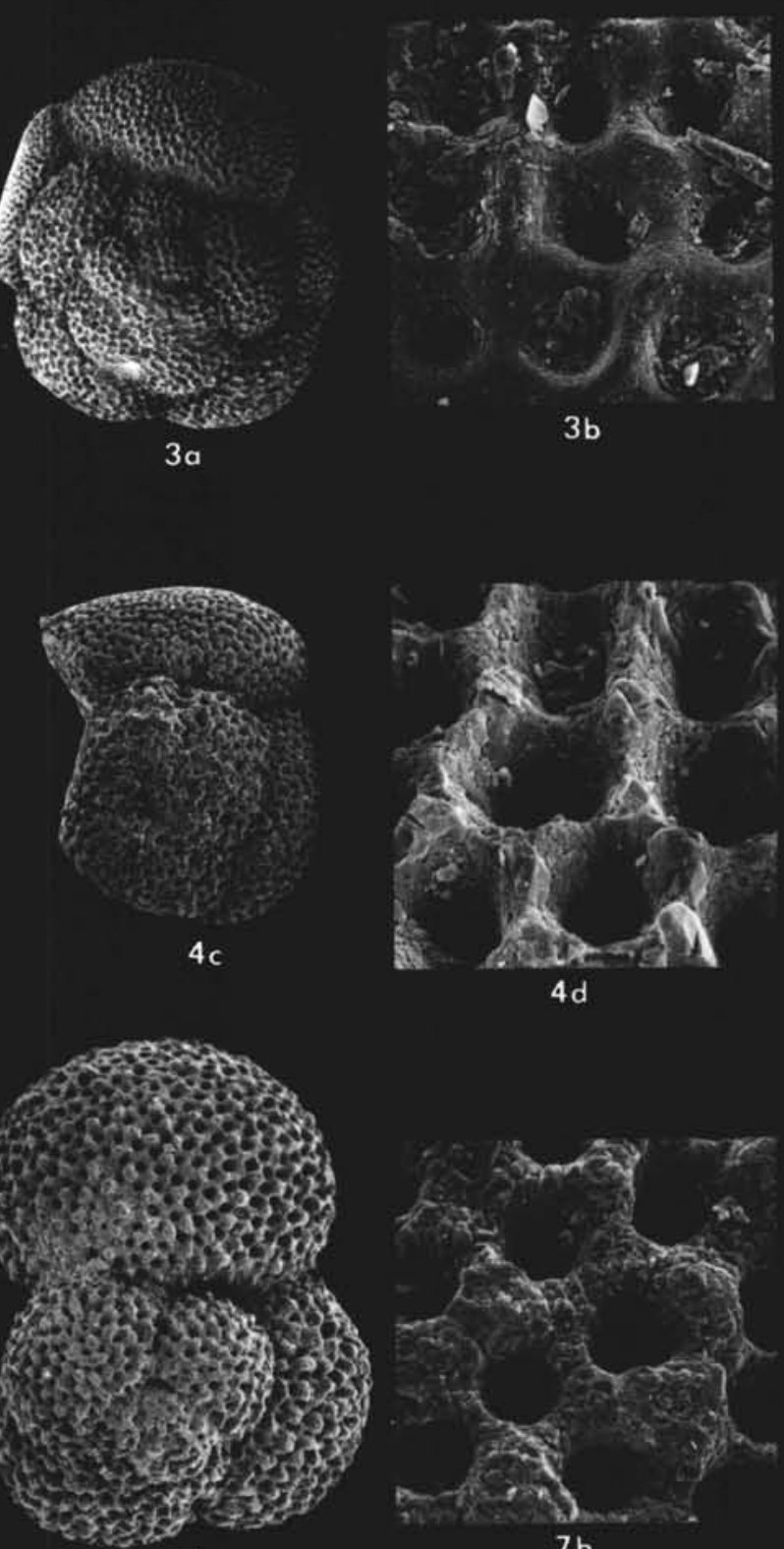

$7 \mathrm{a}$

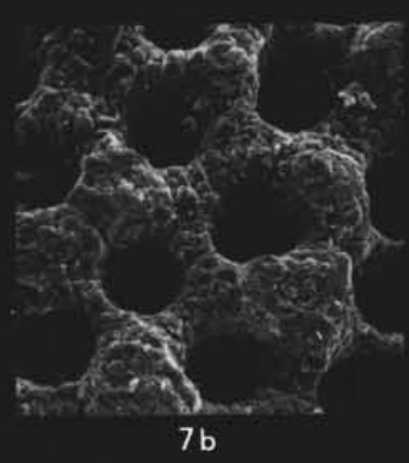

6

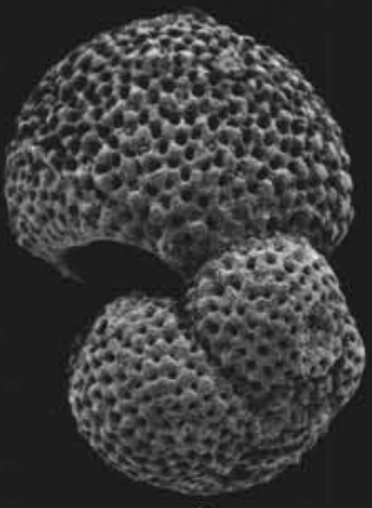

9

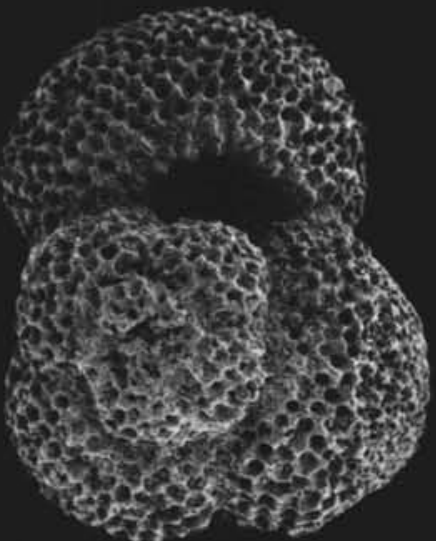

$10 a$

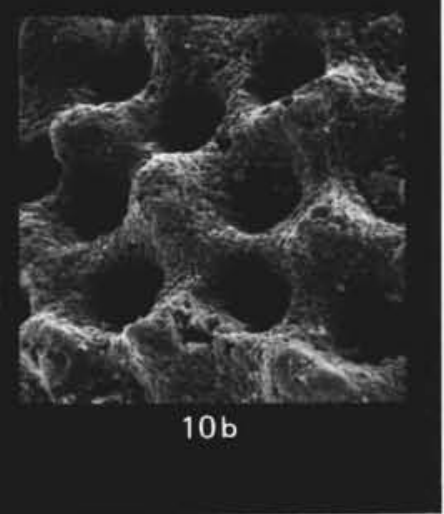




\section{PLATE 3}

Figures 1-3 Globigerinoides altiaperturus Bolli.

Sample 366A-21-4, 63-65 cm, early Miocene.

1. Umbilical view, $\times 150$.

2. Peripheral view, $\times 150$.

3a. Spiral view, $\times 150$.

3b. Ultrastructure of the spiral side of the last chamber, $\times 1000$.

Figures 4-6 Globigerinoides subquadratus Bronnimann.

Sample 366A-17, CC, early Miocene.

4. Umbilical view, $\times 150$.

5. Peripheral view, $\times 150$.

6a. Spiral view, $\times 150$.

6b. Ultrastructure of the spiral side of the last chamber, $\times 1000$.

Figures 7,8 Globigerinoides diminutus Bolli.

Sample 366A-17, CC, early Miocene.

7a. Umbilical view, $\times 150$.

7b. Ultrastructure of the peripheral part of the last chamber, $\times 1000$.

8. Spiral view, $\times 150$.

Figures 9-11 Globigerinoides bollii Blow.

Sample 366A-14-1, 74-75 cm, late Miocene.

9a. Umbilical view, $\times 150$.

9b. Ultrastructure of the peripheral part of the antepenultimate chamber, $\times 1000$.

10. Peripheral view, $\times 150$.

11. Spiral view, $\times 150$. 


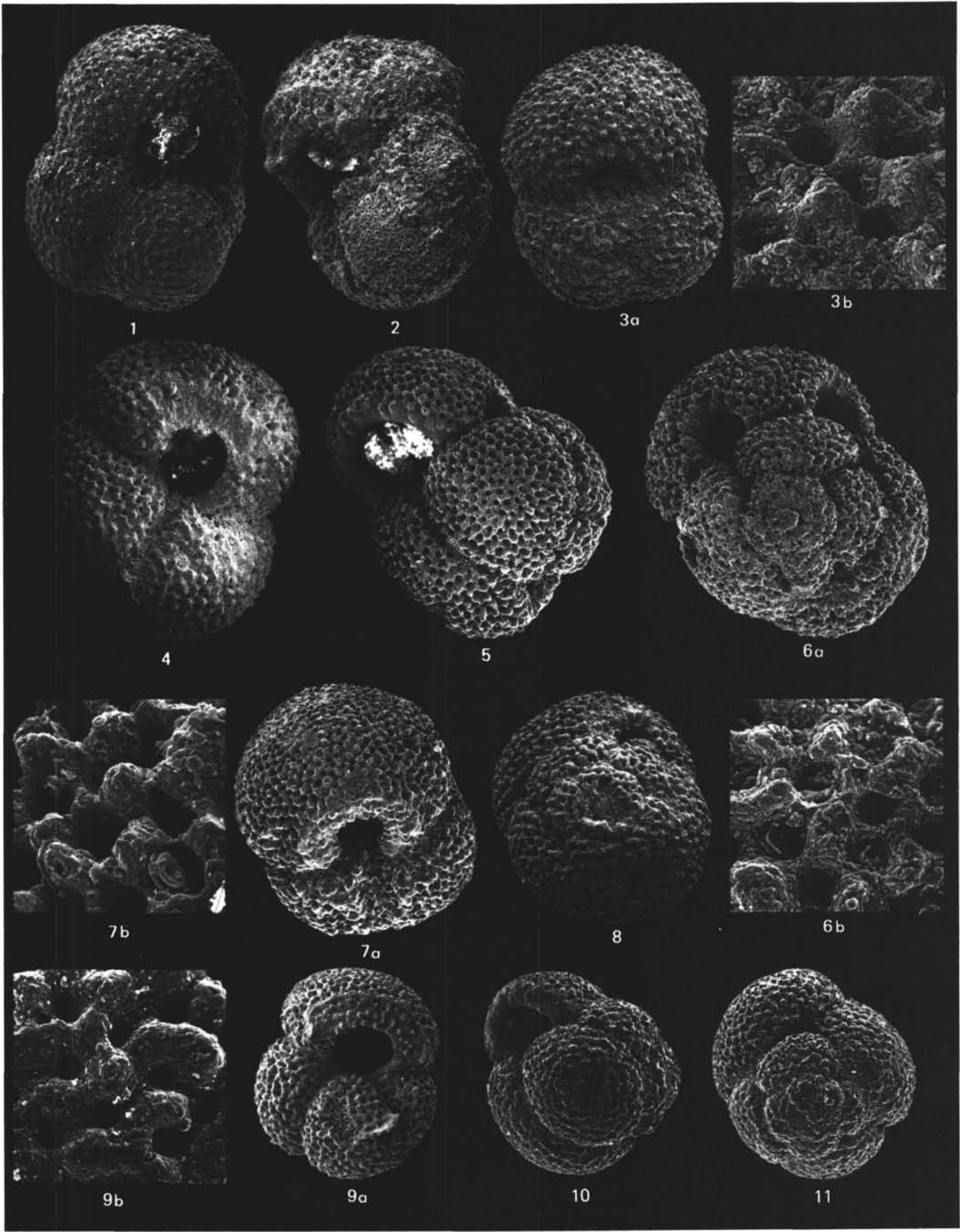




\section{PLATE 4}

Figures 1-3 Globigerinoides obliquus obliquus Bolli.

Sample 366A-8-4, 74-76 cm, early Pliocene.

1. Spiral view, $\times 150$.

2. Peripheral view, $\times 150$.

3a. Umbilical view, $\times 50$.

$3 \mathrm{~b}$. Ultrastructure of the umbilical side of the last chamber, $\times 1000$.

Figures 4-6 Globigerinoides obliquus extremus Bolli and Bermudez.

Sample 366A-8-6, 64-66 cm, early Pliocene.

4 a. Umbilical view, $\times 150$.

4b. Ultrastructure of the umbilical side of the last chamber, $\times 1000$.

5. Spiral view, $\times 150$.

6. Peripheral view, $\times 150$.

Figures 7-9 Globigerinoides fistulosus (Schubert).

Sample 366A-5, CC, middle Pliocene.

7a. Umbilical view, $\times 50$.

7b. Ultrastructure of the umbilical side of the last chamber, $\times 1000$.

8. Spiral view, $\times 50$.

9. Peripheral view, $\times 50$. 


\section{PLATE 4}

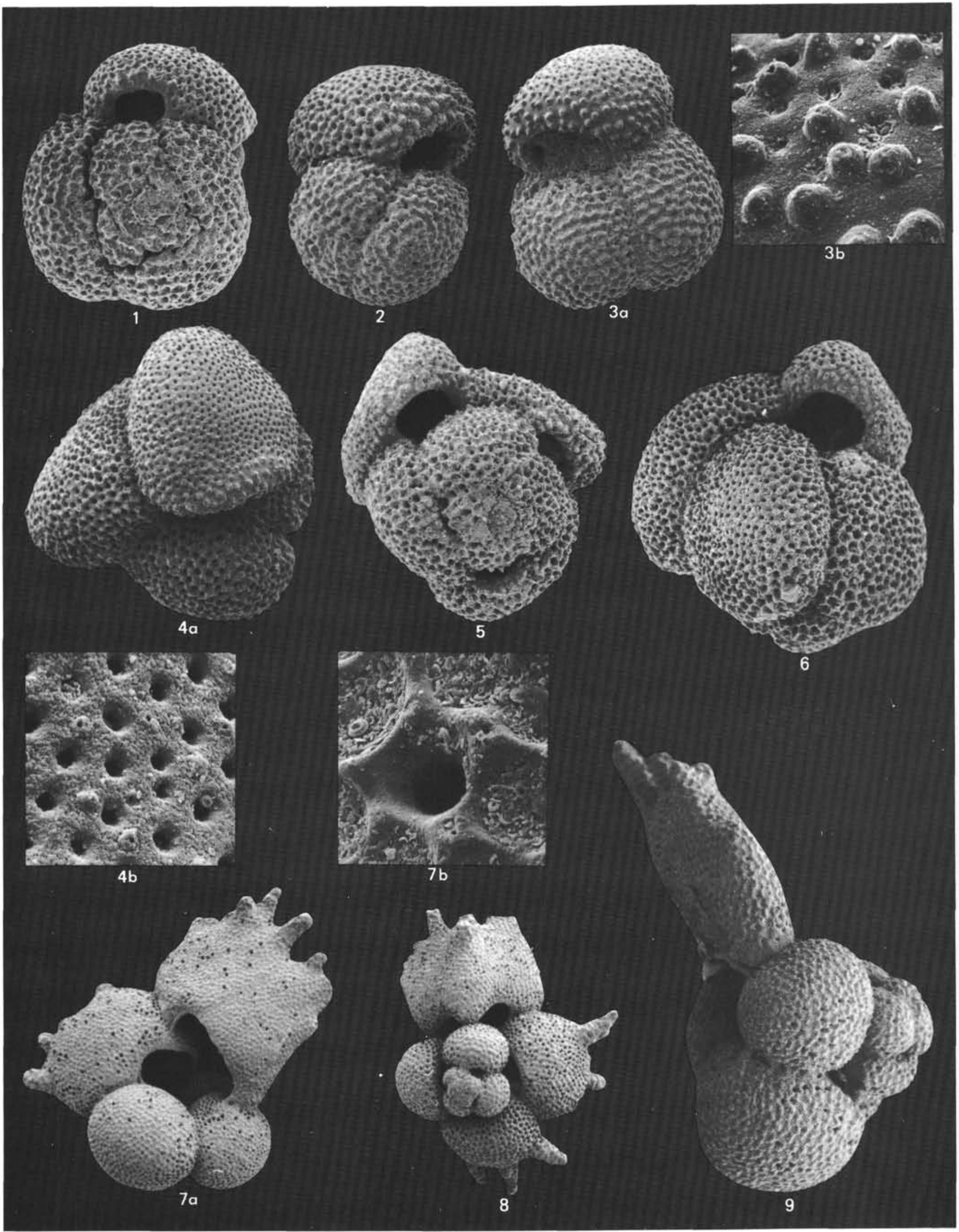




\section{PLATE 5}

Figure $1 \quad$ Globigerinoides bisphaericus Todd.

Sample 369A-8, CC, early Miocene.

la. Umbilical view, $\times 150$.

1b. Ultrastructure of the umbilical side of the last chamber, $\times 1000$.

Figure 2 Globigerinoides bisphaericus Todd, transitional to Praeorbulina sp.

Sample 369A-8, CC, early Miocene.

2a. Peripheral oblique view, $\times 150$.

2b. Ultrastructure of the peripheral part of the last chamber, $\times 1000$.

Figure $3 \quad$ Praeorbulina glomerosa curva (Blow).

Sample 369A-8, CC, early Miocene.

Oblique spiral view, $\times 150$.

Figure $4 \quad$ Praeorbulina glomerosa curva (Blow).

Sample 369A-9-3, 85-87 cm, early Miocene.

4a. Oblique spiral view, $\times 150$.

4b. Ultrastructure of the spiral side of the penultimate chamber, $\times 1000$.

Figure 5 Praeorbulina glomerosa glomerosa (Blow).

Sample 369A-7, CC, early Miocene.

5 a. Oblique spiral view, $\times 150$.

$5 b$. Ultrastructure of the spiral side of the penultimate chamber, $\times 1000$.

Figure $6 \quad$ Praeorbulina glomerosa circularis (Blow).

Sample 369A-7-4, 64-66 cm, early Miocene.

6 a. Oblique spiral view, $\times 150$.

$6 \mathrm{~b}$. Ultrastructure of the spiral side of the antepenultimate chamber, $\times 1000$. 
PLATE 5

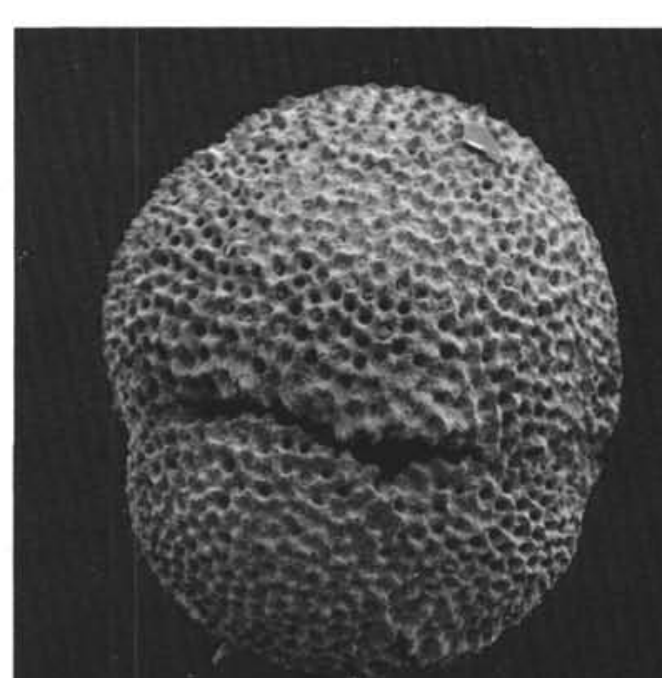

1a

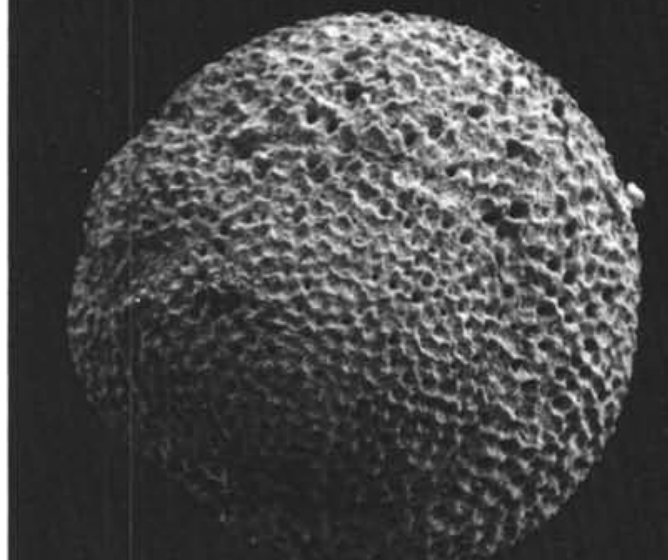

3

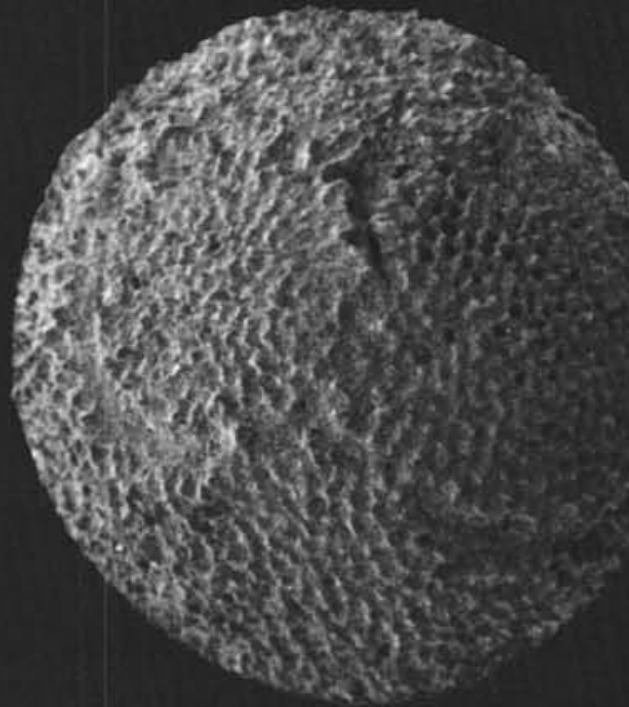

$5 a$

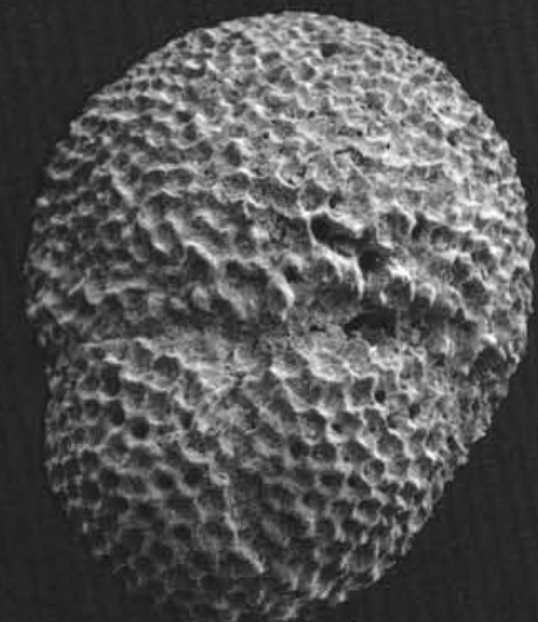

$2 a$

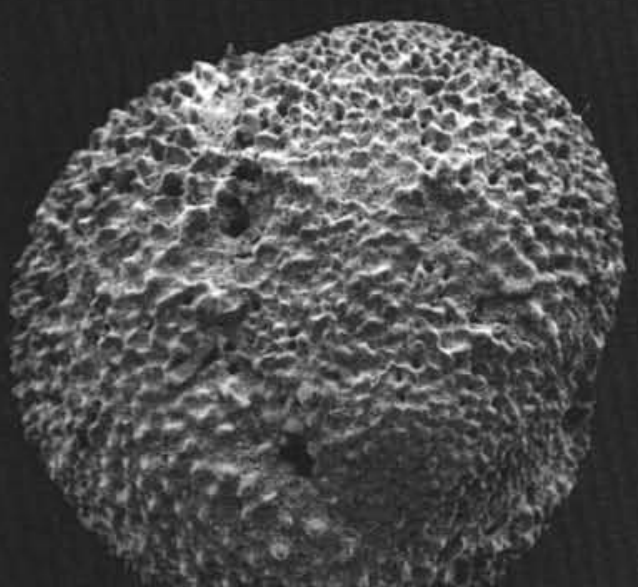

$4 a$

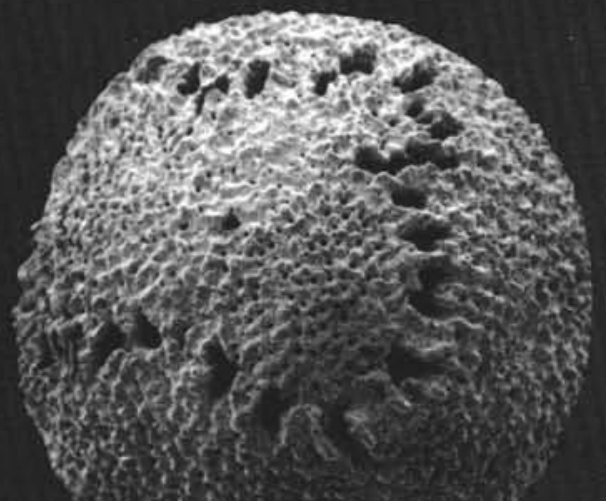

$6 a$
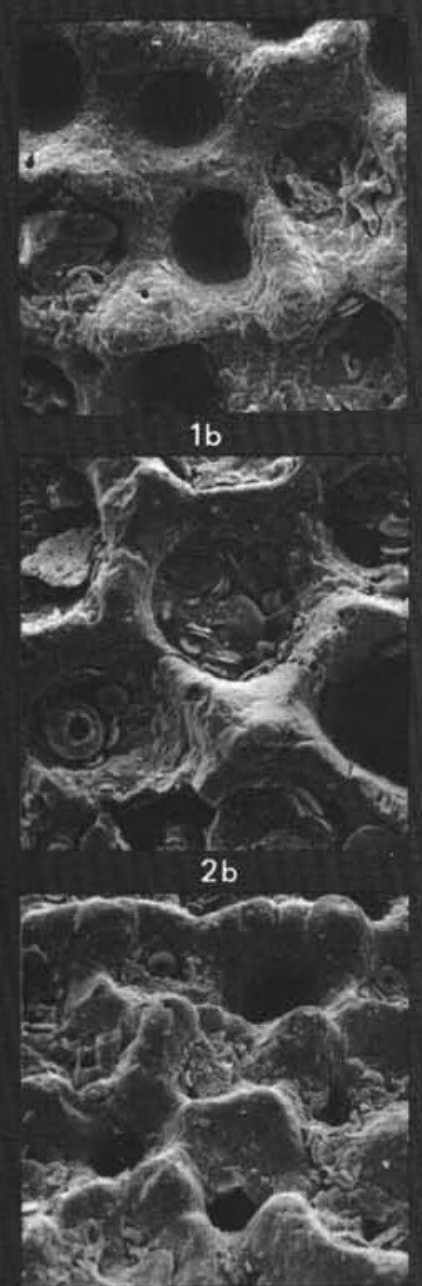

$4 b$

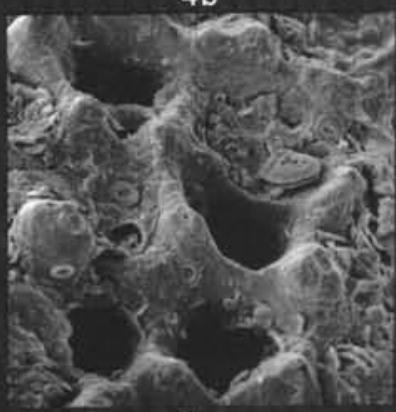

$5 b$

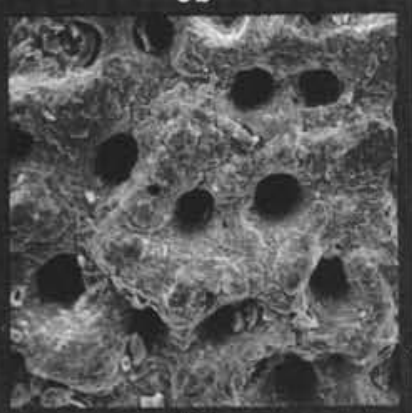

$6 b$ 


\section{PLATE 6}

Figures 1,2 Praeorbulina transitoria (Blow).

Sample 369A-6-1, 63-65 cm, early Miocene.

1. Spiral view, $\times 75$.

2. Umbilical view, $\times 75$.

Figure 3 Praeorbulina transitoria (Blow).

Sample 369A-9-3, 85-87 cm, early Miocene.

3a. Peripheral view, $\times 75$.

$3 \mathrm{~b}$. Ultrastructure of the peripheral part of the last chamber, $\times 1000$.

Figure 4 Biorbulina bilobata (d'Orbigny).

Sample 366A-8-2, 53-55 cm, early Pliocene.

4 a. Lateral view, $\times 75$.

$4 \mathrm{~b}$. Ultrastructure of the wall of the last chamber, $\times 1000$.

Figure 5 Biorbulina bilobata (d'Orbigny).

Sample 366A-12-5, 64-66 cm, late Miocene.

5 a. Lateral view, $\times 75$.

5 b. Ultrastructure of the wall of the penultimate chamber, $\times 1000$,

Figure 6 Orbulina suturalis Bronnimann.

Sample 369A-5-2, 64-66 cm, middle Miocene.

6a. Lateral view, $\times 150$.

$6 \mathrm{~b}$. Ultrastructure of the area of the multiple aperture, $\times 1000$.

Figure $7 \quad$ Orbulina suturalis Bronnimann.

Sample 369A-6-3, 64-66 cm, middle Miocene.

Lateral view, $\times 150$.

Figure $8 \quad$ Orbulina universa d'Orbigny.

Sample 366A-8-2, 53-55 cm, early Pliocene.

8 a. Lateral view, $\times 150$.

8 b. Ultrastructure of the wall, $\times 1000$.

Figure 9 Orbulina universa d'Orbigny.

Sample 366A-12-5, 64-66 cm, late Miocene.

9a. Lateral view, $\times 150$.

9 b. Ultrastructure of the wall, $\times 1000$. 


\section{PLATE 6}

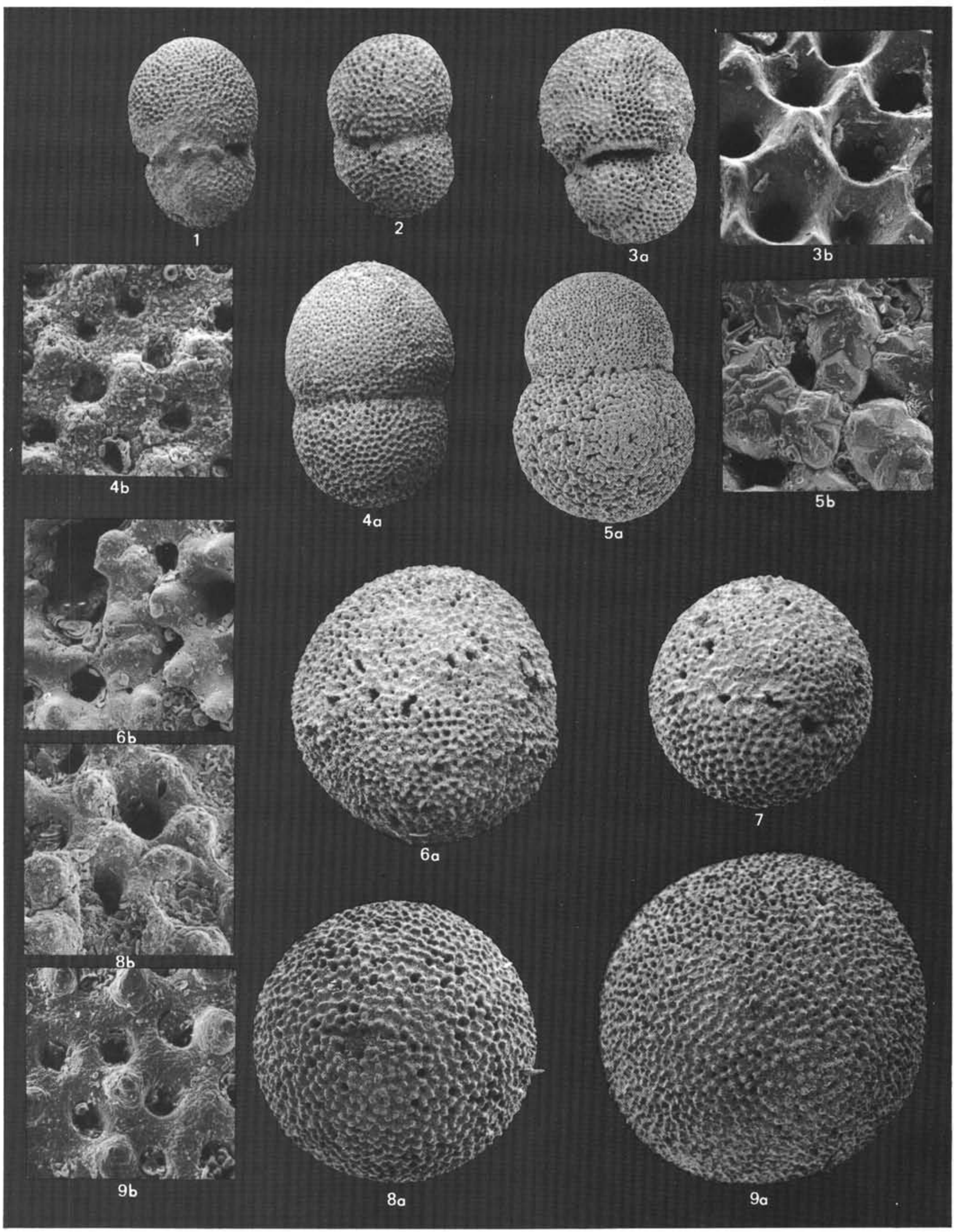




\section{PLATE 7}

Figures 1-3 Sphaeroidinellopsis sphaeroides (Lamb).

Sample 366A-8-6, 64-66 cm, early Pliocene.

1a. Spiral view, $\times 75$.

1b. Ultrastructure of the peripheral area of the last chamber, $\times 1000$.

2. Peripheral oblique view, $\times 75$.

3. Umbilical view, $\times 75$.

Figures 4-6 Sphaeroidinellopsis subdehiscens (Blow).

Sample 366A-8-2, 53-55 cm, early Pliocene.

$4 a$. Umbilical view, $\times 75$.

4b. Ultrastructure of the umbilical part of the last chamber, $\times 1000$.

5. Peripheral view, $\times 75$.

6. Spiral view, $\times 75$.

Figures 7-10 Sphaeroidinellopsis seminulina (Schwager).

Sample 366A-8-2, 53-55 cm, early Pliocene.

7a. Spiral view, $\times 75$.

7b. Ultrastructure of the peripheral part of the last chamber, $\times 1000$.

8. Peripheral view, $\times 75$.

9. Umbilical view, $\times 75$.

10. Umbilical view, $\times 75$.

Figure $11 \quad$ Pulleniatina primalis Banner and Blow. Sample 366A-8-4, 74-76 cm, early Pliocene.

Figures 12-14 Pulleniatina primalis Banner and Blow.

Sample 366A-4-4, 64-66 cm, late Pliocene.

12a. Spiral view, $\times 75$.

12b. Ultrastructure of the spiral side of the last chamber, $\times 1000$,

13. Peripheral view, $\times 75$.

14a. Umbilical view, $\times 75$.

14b. Ultrastructure of the umbilical side of the antepenultimate chamber, $\times 1000$. 


\section{PLATE 7}

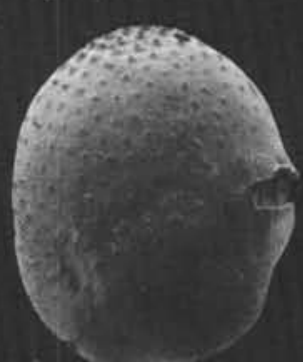

1a

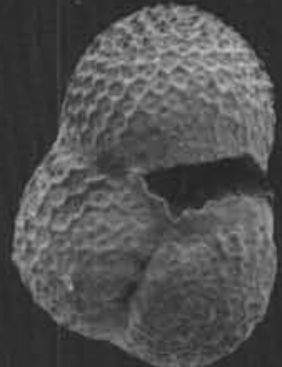

$4 a$
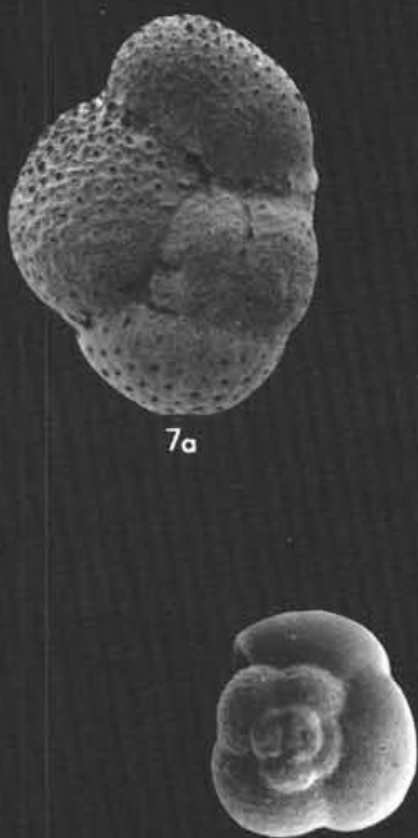

11
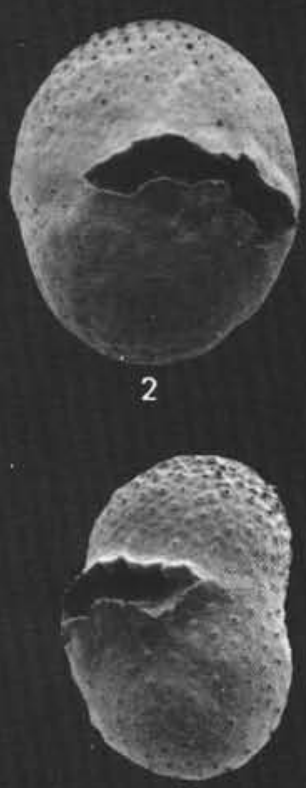

5

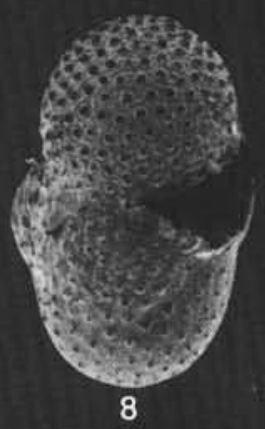

3
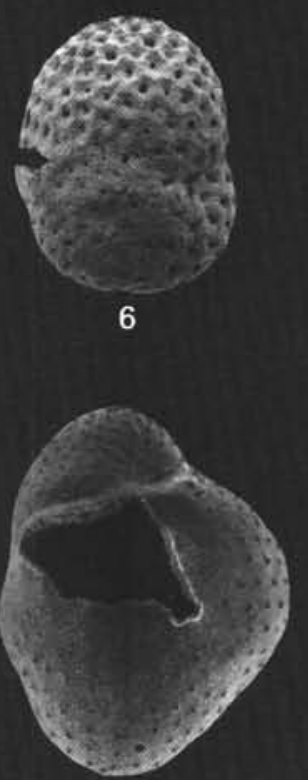

9

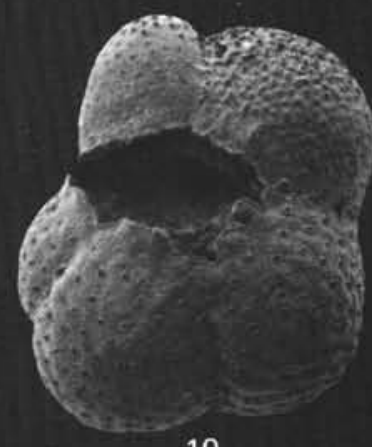

10

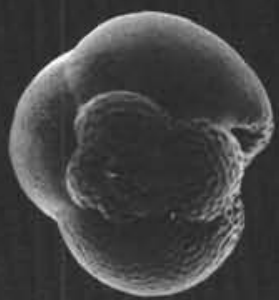

$12 a$

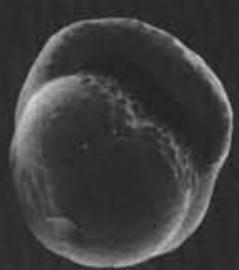

13

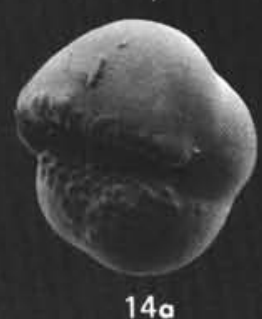

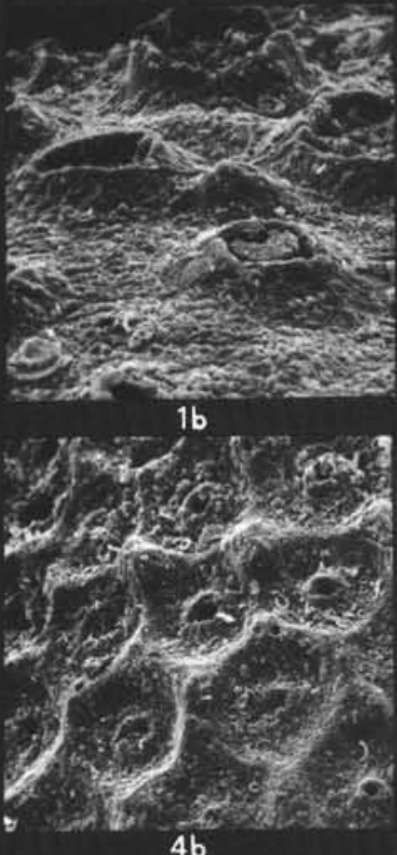
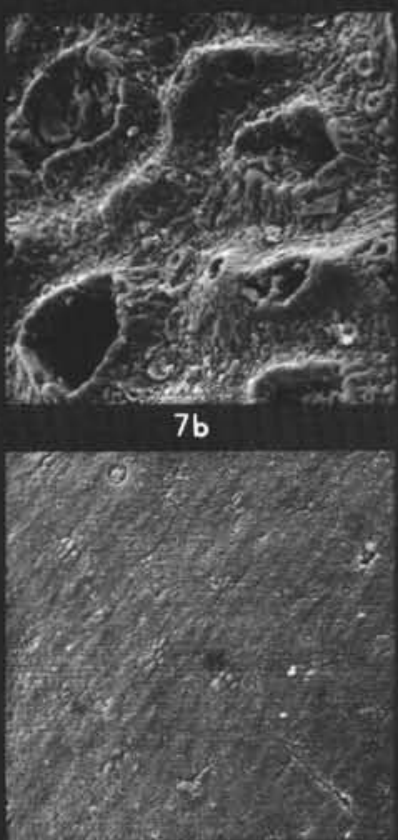

$12 b$

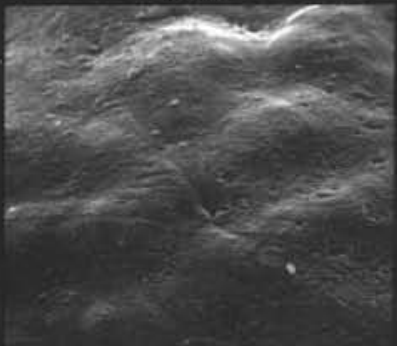

$14 b$ 


\section{PLATE 8}

Figures 1,2 Globorotalia kugleri Bolli.

Sample 366A-26-4, 72-74 cm, early Miocene.

1a. Spiral view, $\times 150$.

1b. Ultrastructure of the spiral side of the last chamber, $\times 1000$.

2a. Peripheral view, $\times 150$.

2b. Umbilical view, $\times 150$.

Figures 3-5 Globorotalia siakensis Le Roy.

Sample 369A-6-3, 64-66 cm, middle Miocene.

3. Umbilical view, $\times 150$.

4. Peripheral view, $\times 150$.

5a. Spiral view, $\times 150$.

5 b. Ultrastructure of the spiral side of the last chamber, $\times 1000$.

Figures 6-8 Globorotalia acostaensis Blow.

Sample 366A-14-2, 71-73 cm, late Miocene.

6a. Umbilical view, $\times 150$.

6b. Ultrastructure of the umbilical side of the last chamber, $\times 1000$.

7. Peripheral view, $\times 150$.

8. Spiral view, $\times 150$.

Figures 9, 10 Globorotalia pseudopima Blow.

Sample 366A-4-3, 110-112 cm, late Pliocene.

9 a. Spiral view, $\times 150$.

$9 \mathrm{~b}$. Ultrastructure of the spiral side of the last chamber, $\times 1000$,

10. Umbilical view, $\times 150$. 
PLATE 8

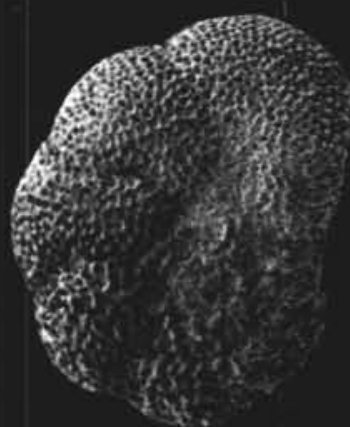

1a

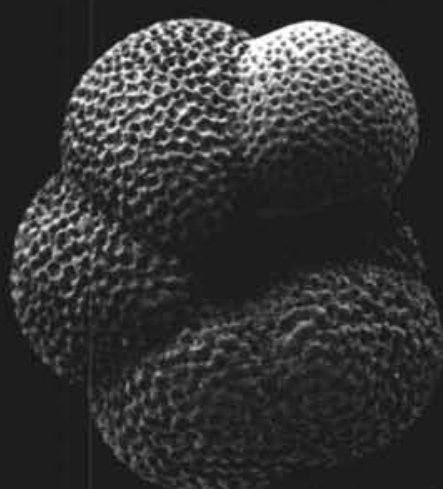

3

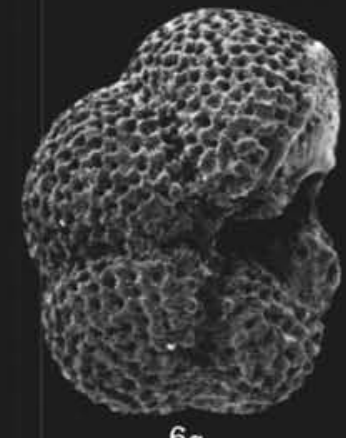

6。

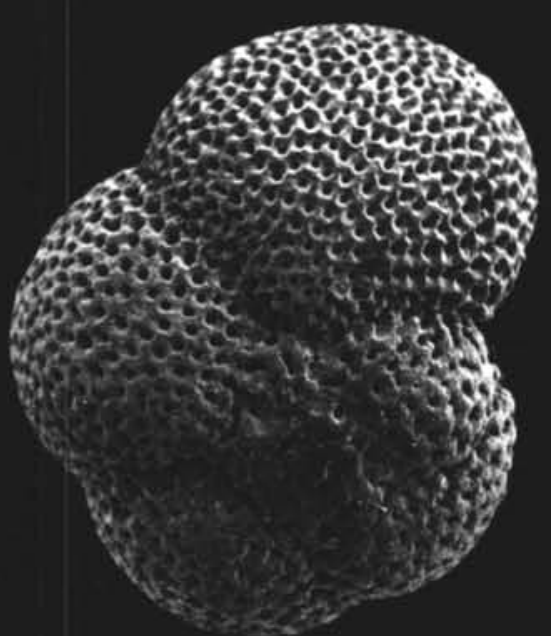

$9 a$

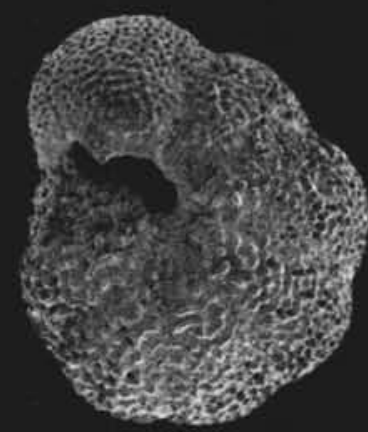

$2 b$

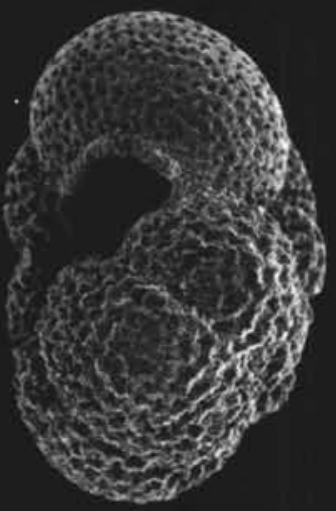

4
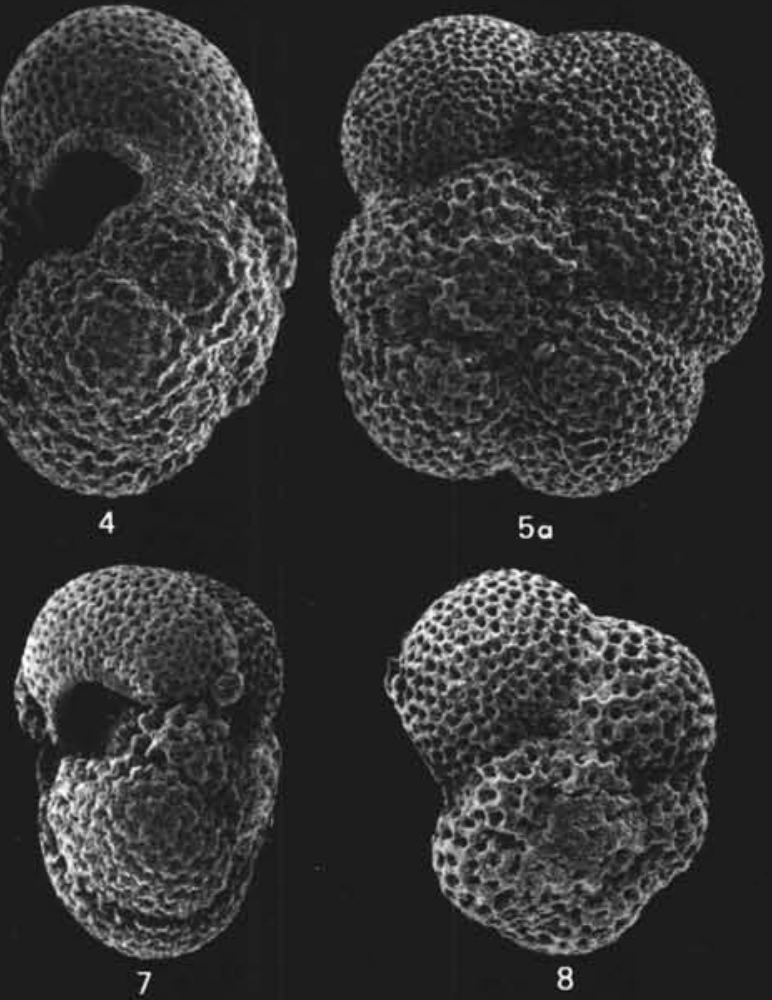

$5 a$

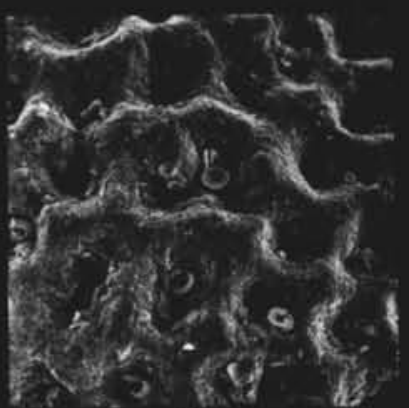

$5 b$
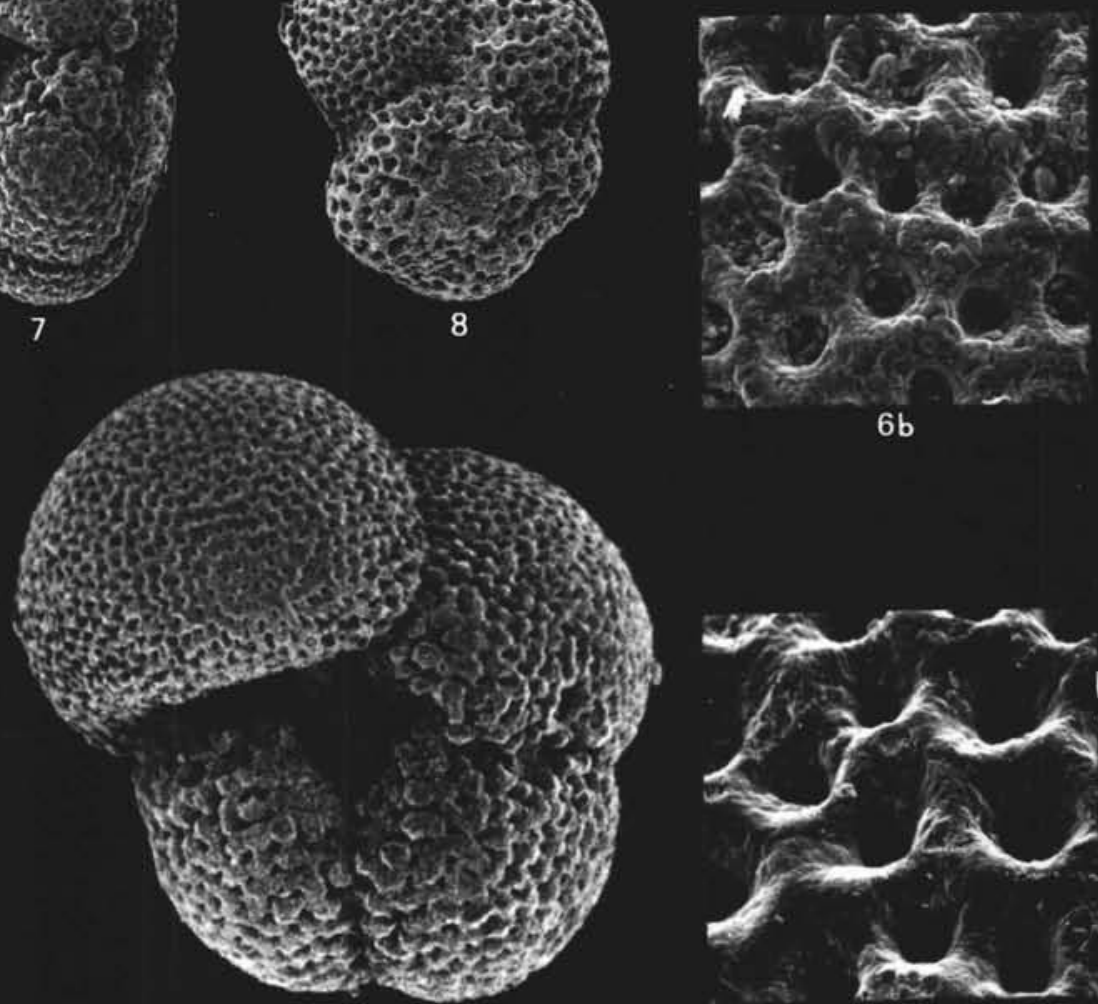

10

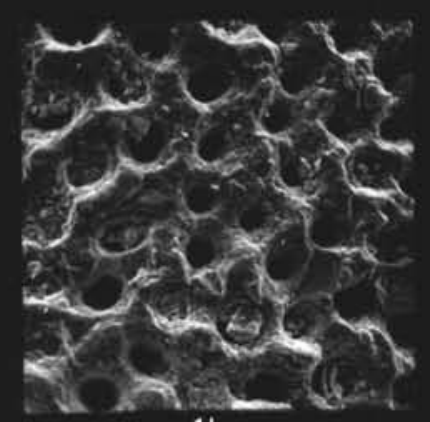

16

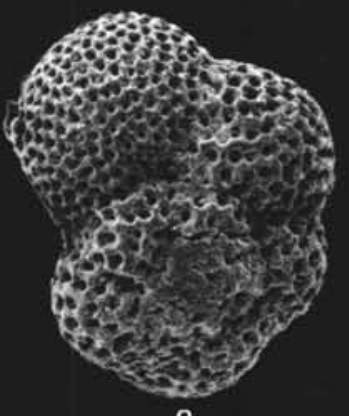

8

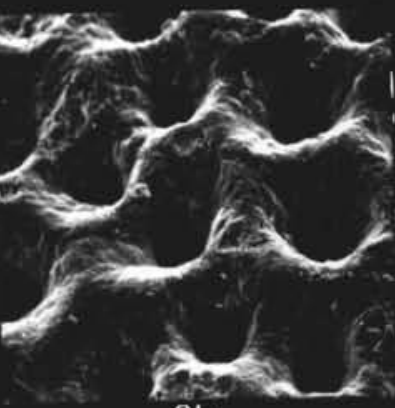

$9 b$ 


\section{PLATE 9}

Figures 1,2 Globorotalia fohsi lobata Bermudez.

Sample 366A-15-3, 61-63 cm, middle Miocene.

1a. Umbilical view, $\times 75$.

1b. Ultrastructure of the umbilical side and keel of the last chamber, $\times 1000$.

2a. Peripheral view, $\times 75$.

2b. Spiral view, $\times 75$.

2c. Ultrastructure of the spiral side of the last chamber at the edge of the apertural face, $\times 1000$.

Figures 3-5 Globorotalia fohsi lobata Bermudez.

Sample 366A-15-4, 61-63 cm, middle Miocene.

3. Ultrastructure of the keel of the last chamber, $\times 500$.

4. Umbilical view, $\times 75$.

5a. Peripheral view, $\times 75$.

5 b. Spiral view, $\times 75$.

5c. Ultrastructure of the spiral side of the last chamber, $\times 1000$.

Figures 6-8 Globorotalia fohsi fohsi Cushman and Ellisor.

Sample 366A-15, CC, middle Miocene.

6. Umbilical view, $\times 75$.

7a. Peripheral view, $\times 75$

7b. Ultrastructure of the keeled periphery of the last chamber (near the apertural face), $\times 500$.

8a. Spiral view, $\times 75$.

8 b. Ultrastructure of the spiral side of the last chamber, $\times 1000$.

Figures 9-11 Globorotalia peripheroacuta Blow and Banner.

Sample 366A-15, CC. middle Miocene.

9. Umbilical view, $\times 75$.

10a. Peripheral view, $\times 75$.

10b. Ultrastructure of the peripheral margin of the last chamber, which is nearly keeled; peripheral rim is porous, as it is seen in a broken part of the shell, $\times 500$.

11a. Spiral view, $\times 75$.

11b. Ultrastructure of the spiral side of the last chamber, $\times 1000$.

Figures 12-14 Globorotalia peripheroronda Blow and Banner.

Sample 369A-6-2, 64-66 cm, middle Miocene.

12a. Spiral view, $\times 75$.

$12 \mathrm{~b}$. Ultrastructure of the spiral side of the last chamber, $\times 1000$.

13a. Peripheral view, $\times 75$.

13b. Ultrastructure of the porous periphery in the middle of the last volution, $\times 1000$.

14. Umbilical view, $\times 75$. 


\section{PLATE 9}

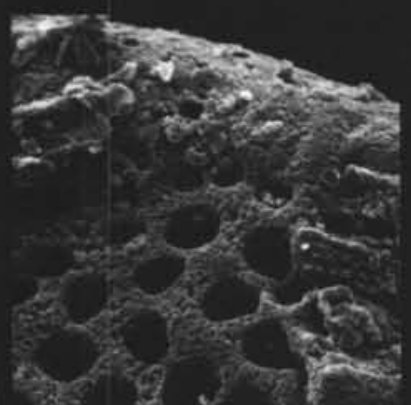

$1 b$

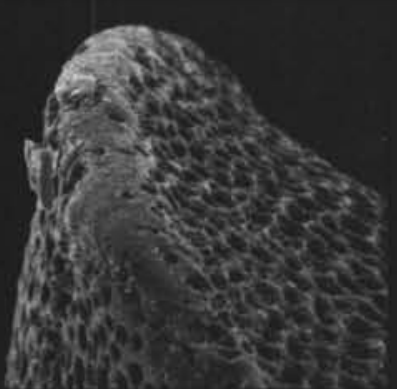

3

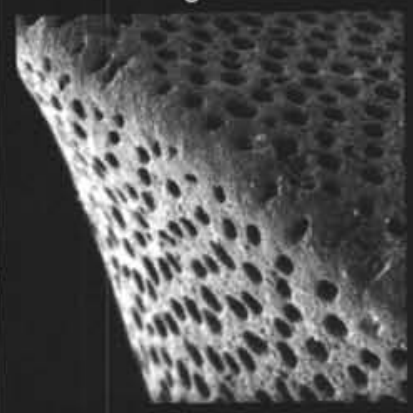

$7 b$

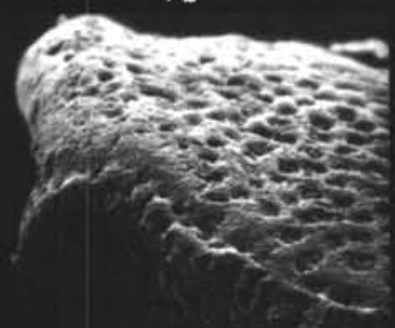

$10 \mathrm{~b}$

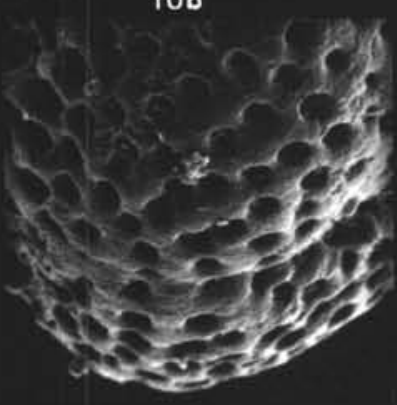

13b
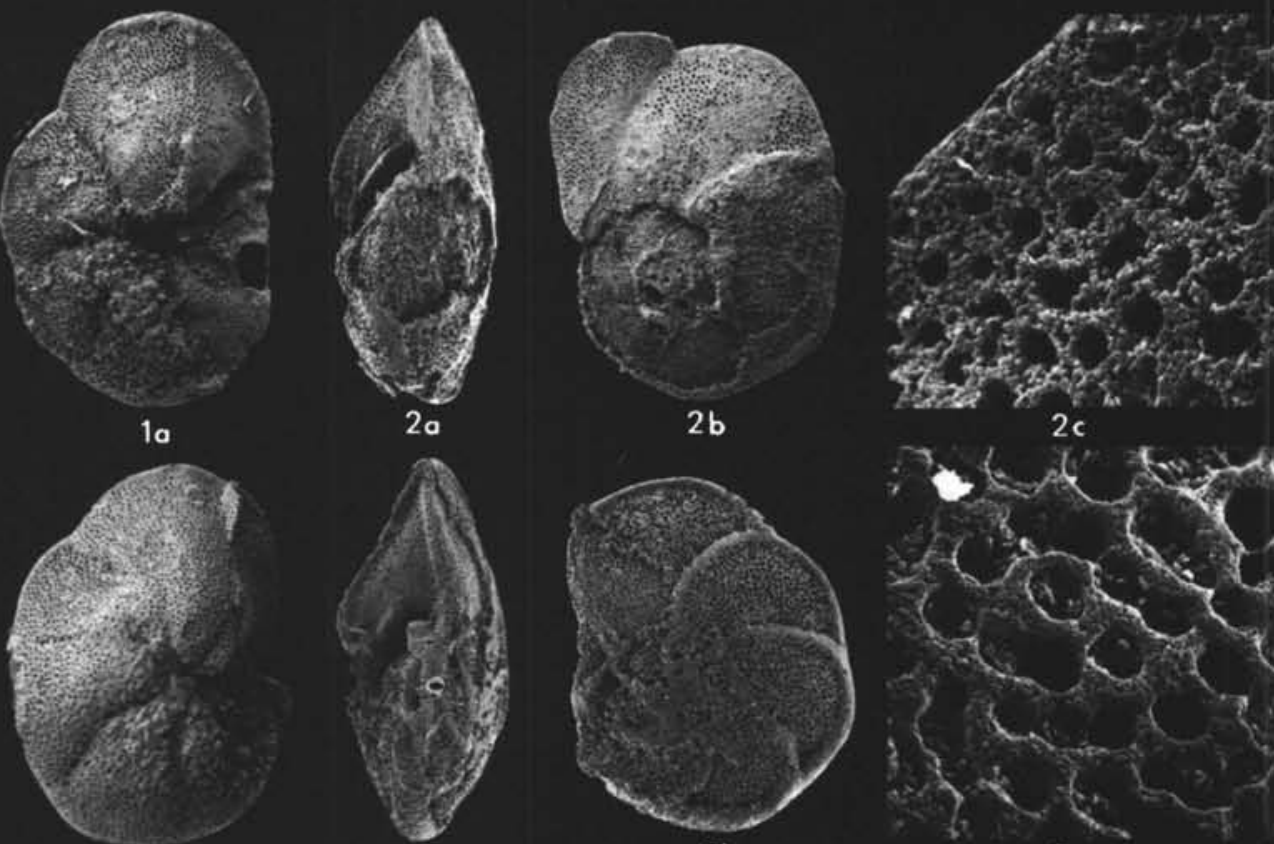

4

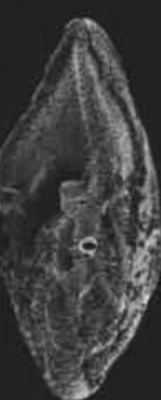

$5 a$

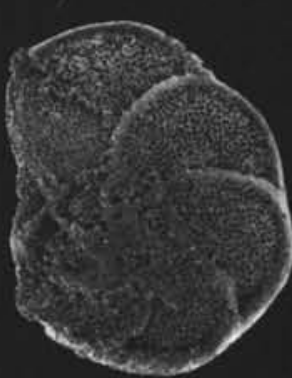

$5 b$

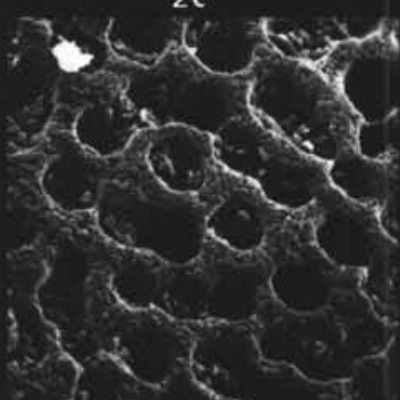

$5 c$

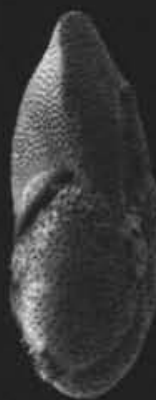

70

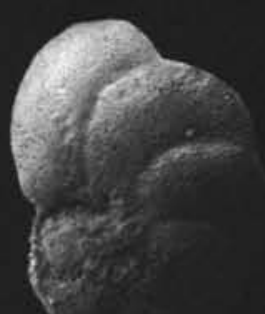

$8 a$

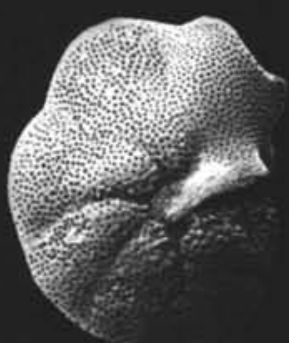

9

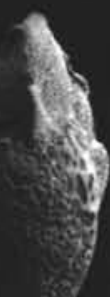

$10 a$

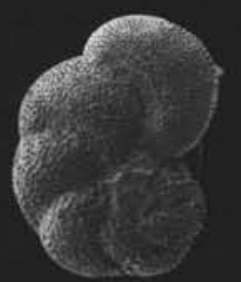

120

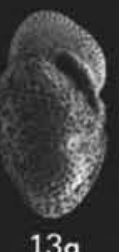

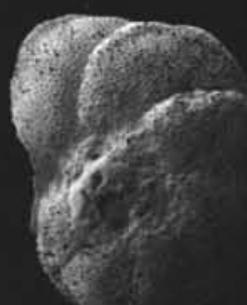

110

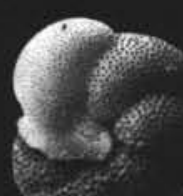

14

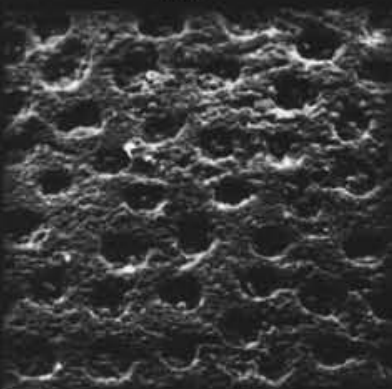

$8 b$

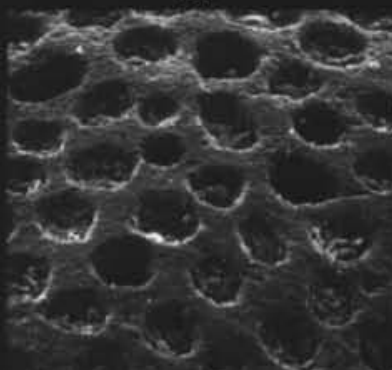

$11 \mathrm{~b}$

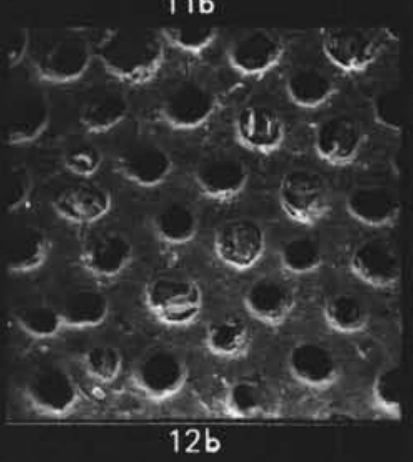




\section{PLATE 10}

Figures 1-3 Globorotalia margaritae evoluta Cita.

Sample 366A-6-1, 83-85 cm, early Pliocene.

1. Umbilical view, $\times 75$.

2a. Peripheral view, $\times 75$.

2b. Ultrastructure of the keeled periphery of the last chamber, $\times 5000$.

3a. Spiral view, $\times 75$.

3b. Ultrastructure of the spiral side of the last chamber, $\times 1000$.

Figures 4-6 Globorotalia margaritae margaritae Bolli and Bermudez.

Sample 366A-8-6, 64-66 cm, early Pliocene.

4. Umbilical view, $\times 75$.

5a. Peripheral view, $\times 75$.

5 b. Ultrastructure of the keeled periphery in the middle of the last volution, $\times 500$.

6a. Spiral view, $\times 75$.

$6 \mathrm{~b}$. Ultrastructure of the spiral side of the last chamber, $\times 1000$.

Note: a highly developed specimen of this subspecies transitional to $G$. margaritae evoluta.

Figures 7-9 Globorotalia margaritae margaritae Bolli and Bermudez.

Sample 366A-8-6, 64-66 cm, early Pliocene.

7. Umbilical view, $\times 75$.

8a. Peripheral view, $\times 75$.

$8 \mathrm{~b}$. Ultrastructure of the nonporous peripheral margin in the middle of the last volution, $\times 500$.

9a. Spiral view, $\times 75$.

9b. Ultrastructure of the spiral side of the last chamber, $\times 1000$.

Figures 10-12 Globorotalia margaritae primitiva Cita.

Sample 366A-11-1, 105-107, late Miocene.

10. Umbilical view, $\times 75$.

11a. Peripheral view, $\times 75$.

$11 \mathrm{~b}$. Ultrastructure of the poreless periphery of the last chamber, $\times 500$.

12a. Spiral view, $\times 75$.

12b. Ultrastructure of the spiral side of the last chamber, $\times 1000$.

Figures 13-15 Globorotalia miozea Finlay.

Sample 366A-11-2, 61-63 cm, late Miocene.

13a. Spiral view, $\times 75$.

13b. Ultrastructure of the spiral side of the last chamber, $\times 1000$.

14a. Peripheral view, $\times 75$.

14b. Ultrastructure of the almost poreless margin of the last chamber, $\times 500$.

15. Umbilical view, $\times 75$. 


\section{PLATE 10}

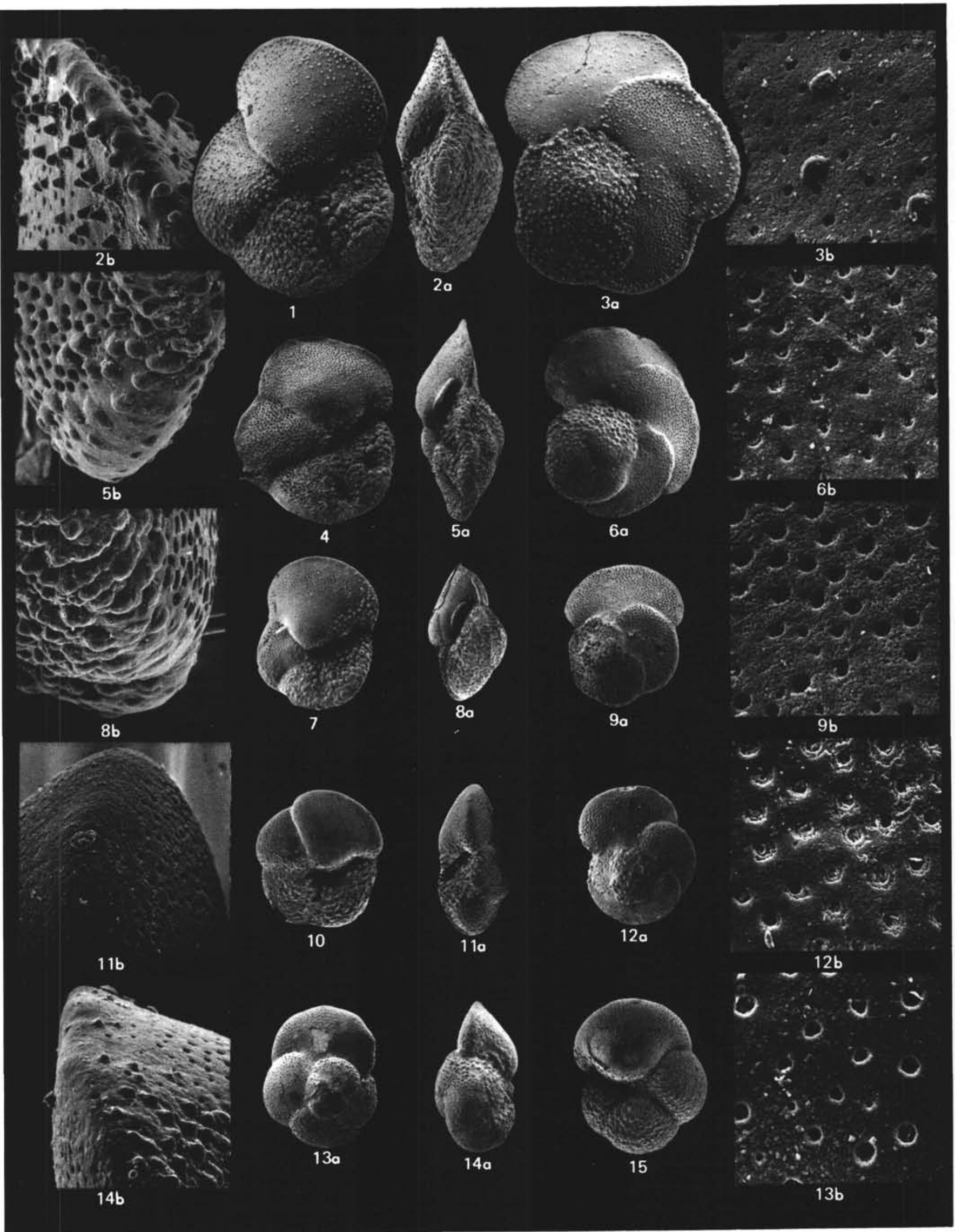




\section{PLATE 11}

Figure 1-3 Globorotalia pseudomiocenica Bolli and Bermudez. Sample 366A-8-5, 64-66 cm, early Pliocene.

1a. Spiral view, $\times 75$.

1b. Ultrastructure of the spiral side of the last chamber, $\times 1000$.

2. Peripheral view, $\times 75$.

3. Umbilical view, $\times 75$.

Figures 4, 5 Globorotalia plesiotumida Blow and Banner.

Sample 366A-11-2, 61-63 cm, late Miocene.

4a. Spiral view, $\times 75$.

4b. Ultrastructure of the spiral side of the last chamber, $\times 1000$.

4c. Peripheral view, $\times 75$.

5. Umbilical view, $\times 75$.

Figures 6-8 Globorotalia praemenardii Cushman and Stainforth.

Sample 369A-3-3, 64-66 cm, middle Miocene.

6. Umbilical view, $\times 75$.

7. Peripheral view, $\times 75$.

8a. Spiral view, $\times 75$.

$8 \mathrm{~b}$. Ultrastructure of the spiral side of the last chamber, $\times 1000$.

8c. Ultrastructure of the keeled periphery of the last chamber, $\times 500$.

Figure $9 \quad$ Globorotalia archaeomenardii Bolli.

Sample 366A-15, CC, middle Miocene.

9 a. Umbilical view, $\times 75$.

9b. Peripheral view, $\times 75$.

9c. Spiral view, $\times 75$.

9d. Ultrastructure of the spiral side of the last chamber, $\times 1000$.

9e. Ultrastructure of the keeled periphery of the last chamber, $\times 500$.

9f. Ultrastructure of the broadly rounded periphery in the middle of the last volution, $\times 500$.

Figure 10 Globorotalia (Clavatorella) bermudezi (Bolli).

Sample 366A-16-5, 66-68 cm, middle Miocene.

10a. Umbilical view, $\times 75$.

10b. Spiral view, $\times 75$.

10c. Ultrastructure of the umbilical side of the last chamber, $\times 1000$. 


\section{PLATE 11}

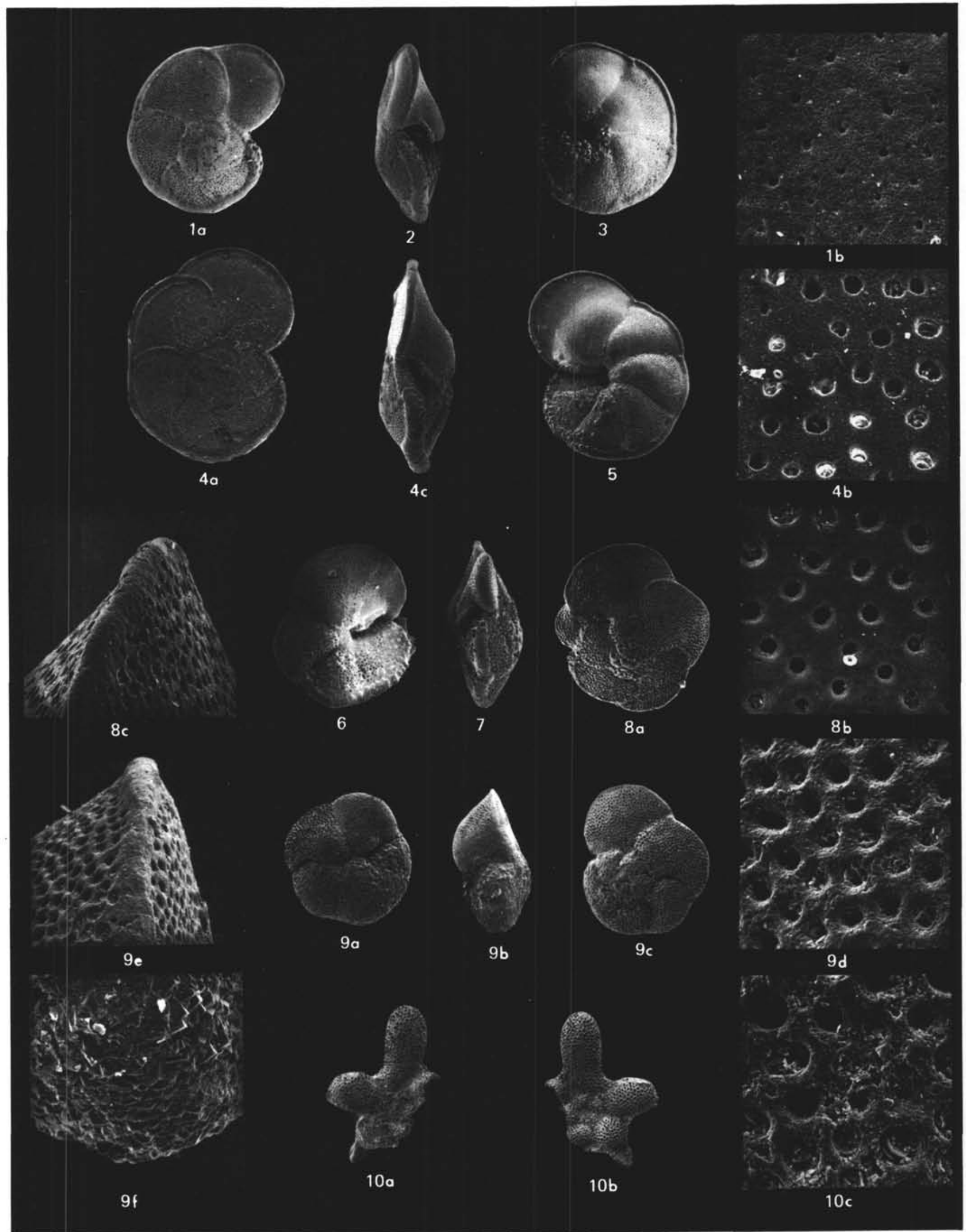




\section{PLATE 12}

Figures 1-3 Globorotalia miocenica Palmer.

Sample 366A-4-6, 31-33 cm, middle Pliocene.

1. Spiral view, $\times 75$.

2. Peripheral view, $\times 75$.

3a. Umbilical view, $\times 75$.

3b. Ultrastructure of the umbilical side of the last chamber, $\times 1000$.

Figures 4-6 Globorotalia exilis Blow.

Sample 366A-4-6, 31-33 cm, middle Pliocene.

4. Spiral view, $\times 75$.

5. Peripheral view, $\times 75$.

6a. Umbilical view, $\times 75$.

$6 \mathrm{~b}$. Ultrastructure of the umbilical side of the last chamber, $\times 1000$.

Figures 7-9 Globorotalia pertenuis Beard.

Sample 366A-8-3, 112-114-cm, early Pliocene.

7. Spiral view, $\times 75$.

8. Peripheral view, $\times 75$.

9a. Umbilical view, $\times 75$.

9 b. Ultrastructure of the umbilical side of the last chamber, $\times 1000$.

Figures 10-12 Globorotalia multicamerata Cushman and Jarvis. Sample 366A-6-5, 33-35 cm, early Pliocene.

10. Spiral view, $\times 75$.

11. Peripheral view, $\times 50$.

12a. Umbilical view, $\times 50$.

12b. Ultrastructure of the umbilical side of the last chamber, $\times 1000$. 

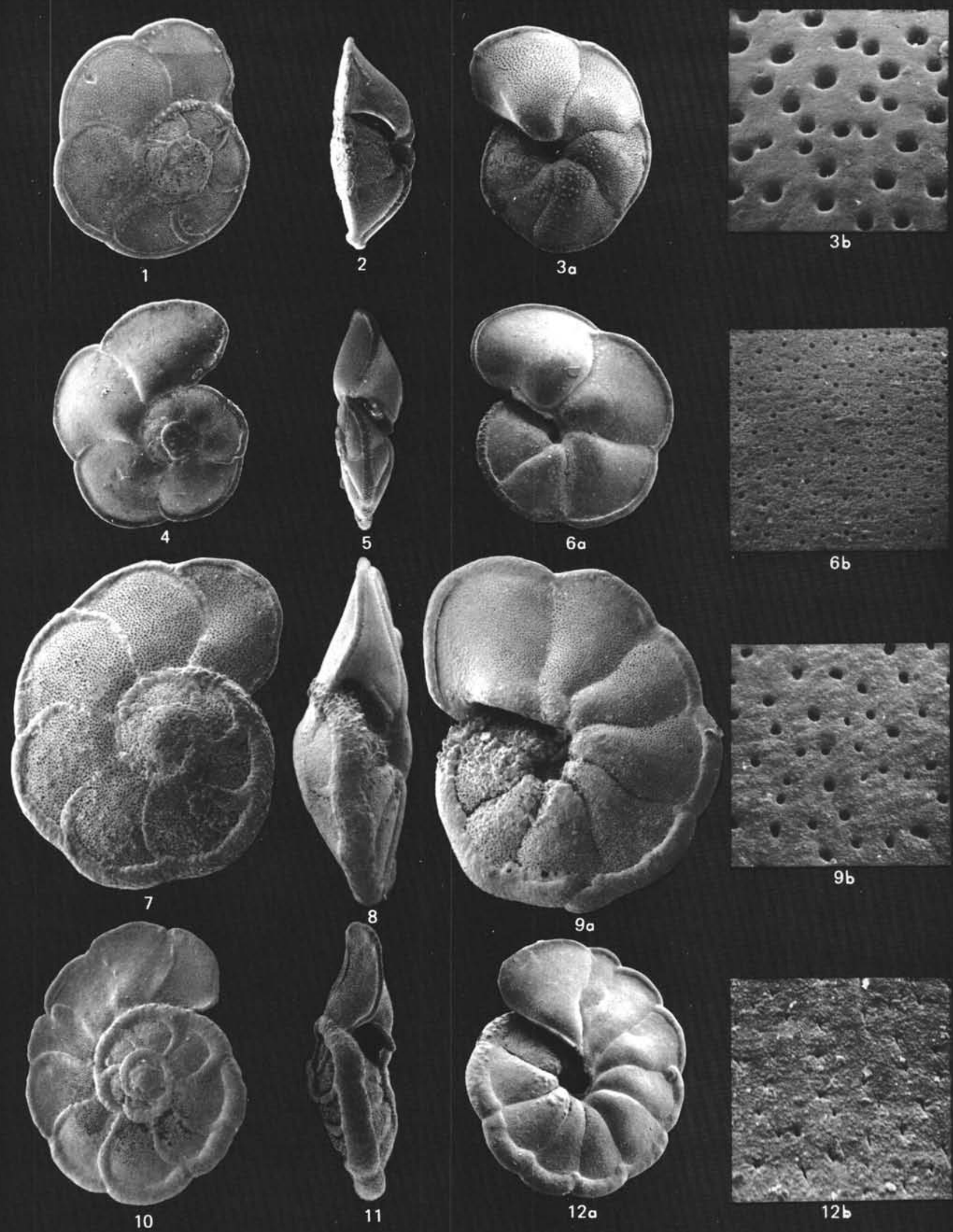